JÉSSICA CÂMARA SIQUEIRA

\title{
AS NOÇÕES DE DOCUMENTO E DE INFORMAÇÃO - UMA ABORDAGEM TERMINOLÓGICA
}

\begin{abstract}
Dissertação de Mestrado apresentada ao Programa de Pós-Graduação em Ciência da Informação da Escola de Comunicações e Artes da USP, como requisito parcial para obtenção do título de Mestre em Ciência da Informação.
\end{abstract}

Orientadora: $\operatorname{Prof}^{\underline{a}}$. Dr ${ }^{\mathrm{a}}$. Marilda Lopes Ginez de Lara

(VERSÃO CORRIGIDA)

São Paulo

2011 
"Comme la même structure ou la même ville peut être représentée par différentes scénographies, suivant des différentes côtes dont on la regarde."

Leibniz 


\section{Agradecimentos}

À Prof. ${ }^{\text {a }}$ Marilda Lopes Ginez Lara pela orientação prestada para o desenvolvimento deste trabalho, sinônimo de competência, paciência e disponibilidade.

Às professoras Cristina Dotta Ortega e Nair Yumiko Kobashi pelas preciosas contribuições na Qualificação, bem como o relevante papel de cada uma em minha formação.

À Lani Luccas, Julietti Andrade, Pablo Derqui e Gabriela Previdello pelas sugestões e contribuições neste trabalho.

Aos colegas que dividiram suas inquietações e suas pesquisas, corroborando o percurso deste trabalho.

A meu marido, pelo incentivo, força e cumplicidade incondicionais.

A todos aqueles que, direta ou indiretamente, contribuíram para a realização deste trabalho.

Muito Obrigada! 
SIQUEIRA, Jéssica Câmara. A noção de documento e informação - uma abordagem terminológica. São Paulo, 2011. (Dissertação de Mestrado) - Escola de Comunicação e Artes, Universidade de São Paulo, 2011.

\title{
Resumo
}

A pesquisa analisa os dos termos "documento" e "informação" a partir de uma abordagem terminológica a fim de comparar as noções e identificar traços que auxiliem a melhor delimitação do campo da Ciência da Informação. A compreensão das características identitárias da Ciência da Informação é uma necessidade conjuntural, observada no contexto da pós-modernidade em que a área busca "consolidar-se". O uso da orientação da Teoria Comunicativa da Terminologia, que considera o aspecto pragmático e social dos termos, mostrou-se um recurso importante para demonstrar e justificar a simbiose entre os termos "documento" e "informação", corroborando a caracterização do domínio da Ciência da Informação.

Palavras-chave: Ciência da Informação. Documento. Informação. Terminologia.

\begin{abstract}
The research examines the terms "document" and "information" from a terminological approach, in order to compare the concepts and identify traits that help to better delineate the field of Information Science. The understanding of identity characteristics of Information Science is a necessity circumstantial, viewed in the context of postmodernity in the area seeks to "establish itself". The use of the orientation of the Communicative Theory of Terminology, who considers the pragmatic and social terms, proved to be an important resource to demonstrate and justify the symbiosis between the terms "document" and "information", confirming the characterization of the field of Science Information.
\end{abstract}

Keywords: Information Science. Document. Information. Terminology. 


\section{Lista de quadros}

Quadro 1-Síntese dos autores francófonos para o termo documento. 61

Quadro 2- Síntese dos autores espanhóis para o termo documento................................67

Quadro 3- Síntese dos autores anglo-saxões e escandinavos para o termo documento..72

Quadro 4- Síntese dos autores anglo-saxões e escandinavos para o termo informação..79

Quadro 5- Síntese dos autores francófonos para o termo informação

Quadro 6- Síntese dos autores espanhóis para o termo informação. .85

Quadro 7 - Síntese dos autores brasileiros para o termo documento. .89

Quadro 8 - Síntese dos autores brasileiros para o termo informação . .93

Quadro 9 - Exemplo de ficha de coleta. .96

Quadro 10 - Exemplo de ficha de análise.. .96

Quadro 11 - Exemplo de ficha de síntese. .96

Quadro 12- Quadro comparativo das perspectivas da noção de documento...... 100

Quadro13 - Quadro comparativo das perspectivas da noção de informação. 106 


\section{Sumário}

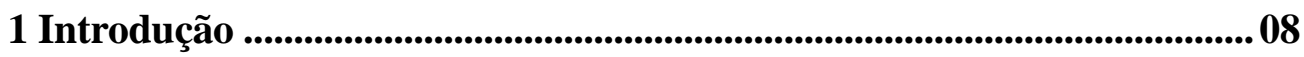

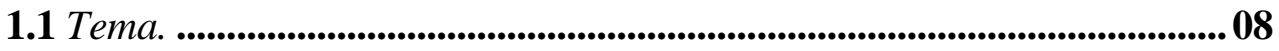

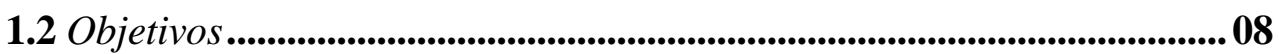

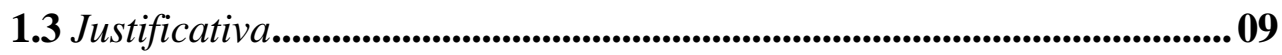

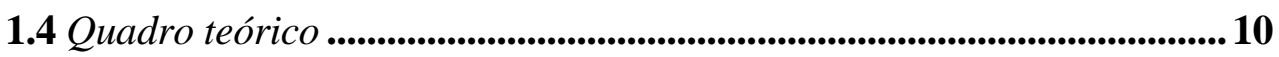

1.4.1 Ciência da Informação..........................................................................10

1.4.2 Breve revisão de literatura dos termos documento e informação......... 12

1.4.2.1 Noções do termo documento .....................................................................12

1.4.2.2 Noções do termo informação .................................................................14

1.4.3 O papel da Terminologia ................................................................17

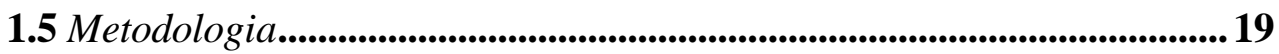

1.5.1 Objeto de estudo .....................................................................................................19

1.5.2 Opções metodológicas .....................................................................19

1.5.3 Procedimentos metodológicos .................................................................20

1.6 Organização do trabalho ...........................................................................24

2 Ciência da Informação: das origens aos dias de hoje ...................................25

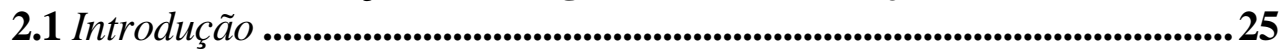

2.2 Ciência da Informação: história e indagações .........................................26

2.3 As nuances do paradigma moderno e do pós-moderno ............................30

2.4 A pós-modernidade e a Ciência da Informação ...............................................35

3 Os estudos terminológicos e a Ciência da Informação...............................39

3.1 Introdução. .............................................................................................................................39

3.2 Terminologia: breve história e principais vertentes.....................................40

3.3 o conceito de Terminologia.................................................................41

3.4 O caráter interdisciplinar da Terminologia ..................................................43

3.5 Terminologia: subsídios para delimitação da Ciência da Informação ............45

3.6 Terminologia: aporte teórico .......................................................................................48

4 Revisão de literatura dos termos "documento" e "informação"..........54

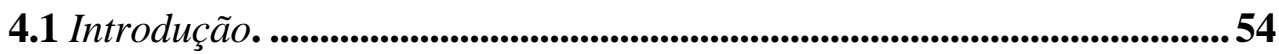


4.2 Noções do termo "documento". 54

4.2.1 Autores francófonos. .......................................................................................................54

4.2.2 Autores espanhóis. .............................................................................61

4.2.3 Autores anglo-saxões e escandinavos. ...................................................67

4.3 Noções do termo "informação". ...............................................................72

4.3.1 Autores anglo-saxões e escandinavos. .............................................................72

4.3.2 Autores francófonos. ..................................................................................................... 79

4.3.3 Autores espanhóis. .........................................................................................81

4.4 Noções dos termos documento e informação para autores nacionais. ...85

4.4.1 A noção do termo documento. ....................................................................85

4.2.2 A noção do termo informação. .............................................................88

5 Noções dos termos documento e informação:

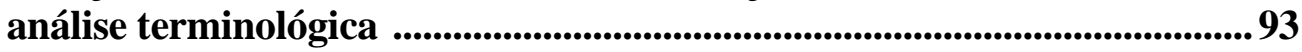

5.1 Descrição metodológica. ......................................................................................93

5.2 A noção do termo "documento" .............................................................96

5.3 A noção do termo "informação", .............................................................103

6 Resultados da análise dos termos documento e informação ..................110

6.1 Introdução. ................................................................................................110

6.2 Proximidades e distinções entre as noções ....................................................111

6.3 Os termos documento e informação e a Ciência da Informação ...........115

7 Considerações finais ............................................................................118

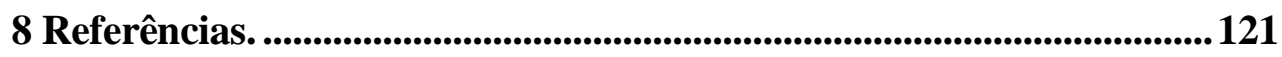

APÊNDICE A- Fichas de análise. ................................................................131

APÊNDICE B- Fichas de síntese. ...................................................................147 


\section{Introdução}

\subsection{Tema}

A pesquisa propõe-se a analisar as noções dos termos "documento" e "informação" a partir de uma abordagem terminológica a fim de verificar traços que auxiliem o delineamento do campo da Ciência da Informação. A abordagem adotada foi a da Teoria Comunicativa da Terminologia, uma vez que ela considera os aspectos pragmático e social dos termos e, desse modo, permite considerá-los de forma mais ampla, contribuindo para a sistematização e o aprofundamento teórico da Ciência da Informação. Por vivermos em um contexto de fragmentações e mudanças de perspectivas, devemos repensar nosso modelo de ciência à luz das idiossincrasias da pós-modernidade.

No decorrer do texto serão utilizadas as seguintes expressões "delineamento" ou "delimitação" do campo da Ciência da Informação ou verificação de "traços identitários" da Ciência da Informação. Observamos que, embora a ciência pósmoderna coloque em questão a circunscrição rigorosa dos campos científicos e, como decorrência, aponte para os problemas de seu vocabulário, o uso dos termos objetiva reunir informações para, mais do que encontrar a configuração precisa do campo da Ciência da Informação, identificar os aspectos que respondem pelo ponto de vista da área relativamente aos conceitos de "documento" e "informação". Além disso, podemos encontrar tais expressões tratando da epistemologia da área, a exemplo de “traços/características identitárias”, utilizadas por Smit e Tálamo (2007).

Diante desse contexto, notamos a necessidade de estudos que valorizem tanto os aspectos conceituais como teóricos, de modo a contribuir para a sistematização das noções da área, corroborando assim uma melhor compreensão do campo da Ciência da Informação.

\subsection{Objetivos}

No contexto histórico social em que vivemos, os patamares organizacionais e estruturais da Ciência se abalam, caracterizando posturas diferentes frente aos fenômenos estudados. O domínio da Ciência da Informação também é vulnerável a tais mudanças, o que se pode verificar em sua literatura. Nela, porém, é possível identificar traços que auxiliem, nesse contexto dinâmico e fragmentado, a compreensão da configuração do campo do conhecimento. 
A Terminologia, no âmbito da vertente contemporânea, mais voltada à compreensão do contexto de uso de um termo do que à sua normalização, pode ajudar nesse trabalho. Nessa perspectiva, pretende-se identificar e compreender as noções e relações entre dois importantes termos da área: "documento" e "informação".

O objetivo desta pesquisa, portanto, é verificar, do ponto de vista terminológico, as relações entre os termos "documento" e "informação", buscando identificar aproximações, distinções e, principalmente, entender como ambos corroboram a caracterização do domínio da Ciência da Informação.

\subsection{Justificativa}

A inserção desta pesquisa no escopo da área de concentração de Cultura e Informação justifica-se por tratar, em última análise, de situações de apropriação social dos sentidos produzidos pelos termos de áreas de especialidade, os quais remetem a referências concretas, bem como são produtos de usos culturais contextualizados. Assim, as relações que caracterizam a construção de sentido podem ser encaradas tanto numa perspectiva simbólica como instrumental, ambas associadas à produção da informação. Insere-se, também, na linha de pesquisa, "Organização da Informação e do Conhecimento" por adotar uma abordagem terminológica permitindo contemplar os trabalhos de organização do conhecimento e da informação do ponto de vista histórico e epistemológico.

A respeito da temática geral, a compreensão dos traços que corroboram o delineamento do campo da Ciência da Informação é resultado tanto de uma necessidade conjuntural, observada na constante tentativa de "consolidação" da Ciência da Informação como área de conhecimento no contexto da pós-modernidade, como fruto de uma inquietação particular que procura encontrar traços mais "tangíveis" para a melhor compreensão da área.

Quanto à escolha dos termos, foi considerada a potencial utilização de noções que tivessem um papel de destaque no campo da Ciência da Informação. Para isso deveriam ser considerados termos que estivessem muito atrelados ao escopo da área. A partir de tal consideração foi selecionado primeiro o termo "informação", presente no próprio nome da área, e até representando para muitos o suposto objeto da área; e num segundo momento o termo "documento", tanto pelo seu papel histórico no bojo do próprio surgimento da Ciência da Informação, como por verificar sua ligação com o termo "informação" em contextos da área. 


\subsection{Quadro teórico}

\subsubsection{Ciência da Informação}

Há diferentes abordagens para as origens da Ciência da Informação. Para Meadows (1999), por exemplo, a Ciência da Informação, assim como a Documentação, deve suas origens ao desenvolvimento científico do século XX que teve seu surgimento muito ligado à ciência em seu sentido lato, considerada como uma decorrência da institucionalização das ciências. Já Le Coadic (2004), parte do contexto histórico do pós-segunda guerra, observando que a Ciência da Informação, no âmbito das ciências sociais, volta-se a um "problema social concreto", a recuperação da informação. O autor destaca a demanda social como elemento propulsor do caráter interdisciplinar da área. Ao lado dessas abordagens do problema, outras se desenvolveram, identificando diferentes origens do campo.

Enquanto na Europa, principalmente continental, houve a aceitação do termo Documentação, desencadeando a criação de centros de documentação, congressos, institutos e a formalização profissional de especialistas, a Inglaterra e os Estados Unidos optaram por utilizar uma terminologia ligada à palavra informação, dando origem aos estudos da Ciência da Informação (ORTEGA, 2009a). Além disso, enquanto a Documentação se desenvolvia na Europa, nos EUA a Biblioteconomia desenvolveu-se enfatizando, de um lado, seu caráter especializado, influenciado pelo breve contato com a Documentação e, de outro, seu caráter generalista, a partir do qual a biblioteca era vista como uma instituição social organizada e definida segundo os parâmetros da Escola de Chicago (SIQUEIRA, 2010).

Além da Europa, a União Soviética também não acatou a expressão "Ciência da Informação", criando o termo Informatika, conceito difundido pelos autores Chernyl, Gilyarevskii e Mikhailov (1973). O objetivo dessa disciplina era estudar a estrutura e as peculiaridades da informação científica, bem como as leis que regiam tal atividade, sua história, teoria, método e formas de organização. O ponto chave era o estudo da informação no contexto comunicativo de um sistema social voltado à mudança de estado do conhecimento, ideia que considerava a informação, como elemento potencial para a transformação de estados anômalos do conhecimento (RADAMÉS LINARES, 2005). 
Os estudiosos russos destacaram-se pelo desenvolvimento de um sólido aparato conceitual. Realizaram tentativas de delimitação do objeto, de distinção dos tipos de documentos e de automatização da busca, o que os aproximou da Documentação. No entanto, o fim do regime socialista, o esgotamento do financiamento para pesquisas e a constatação da ambiguidade do termo "informatika" no Ocidente, acabaram por favorecer a substituição dessa designação pelo termo Ciência da Informação (RADAMÉS LINARES, 2005).

O desenvolvimento da Ciência da Informação, mesmo considerando os vários investimentos, não deixou de mostrar, em seu bojo, várias arestas, principalmente em relação à sua identidade, cuja delimitação tem sido marcada pela afirmação da interdisciplinaridade, por problemas de delimitação de seu objeto de estudo, supostamente enunciado como "informação", termo que, junto com "conhecimento" e "comunicação" lhe dão referência, mas não são suficientes para circunscrever o campo. Além disso, como área que floresceu em meio às fragmentações e relativizações trazidas pelo contexto pós-moderno, é de se esperar que trouxesse mais indagações do que respostas (SIQUEIRA, 2010).

Atualmente, a discussão ainda não chegou a um consenso. Mesmo com a disseminação do termo Ciência da Informação, é notório observar que o campo não está totalmente "delimitado", o que acarreta problemas em sua constituição como área de conhecimento. Já o termo Documentação, que para alguns está rotulado como ultrapassado em comparação à "polivalente” Ciência da Informação, tem como certo seu amplo emprego na Europa e ainda é considerado como área que dá alicerce aos estudos contemporâneos do tratamento da informação.

De forma geral pode-se dizer que a Ciência da Informação preocupa-se em esclarecer um "problema social concreto", o da informação, tendo como objetivo o estudo de suas propriedades (natureza, gênese e efeito) e a análise de seus processos de construção e uso no contexto do trabalho com a informação registrada. Para isso, há basicamente duas correntes: uma que ratifica o viés disciplinar, e outra que enxerga a área a partir de uma visão inter, multi ou transdisciplinar.

No âmbito deste trabalho será considerada a segunda vertente, discutida mais amplamente no primeiro capítulo. O que vale a pena ressaltar neste momento é o atributo da interdisciplinaridade que, embora não seja suficiente para caracterizar a área, mostra que a Ciência da Informação é menos presa às "amarras disciplinares" ao adotar uma perspectivar multifacetada e temática. Por outro lado, as fragmentações e a 
diversidade de olhares desse modelo dificultam o delineamento do campo. Nesse ponto, é salutar buscar identificar aspectos e elementos que contribuam para uma maior compreensão da área, a exemplo dos termos escolhidos para a análise deste trabalho, "documento" e "informação".

\subsubsection{Breve revisão de literatura dos termos "documento" e "informação"}

\subsubsection{Noções do termo documento}

A origem etimológica do termo documento é o latim. O termo, proveniente de documentum, sinônimo de educação e instrução, agrega os significados presentes nos radicais doceo (ensinar) e disco (aprender). A etimologia remete, portanto, a um contexto de ensino e aprendizagem e a uma premissa segundo a qual quem emite uma mensagem espera produzir alguma alteração no outro, o que pode levar a afirmar certa proximidade do conceito ao de "informação". Segundo Reig Cruañes (2005), tanto no aspecto filológico quanto no antropológico, o conceito do termo documento indica um "subproduto" de um processo informativo.

No contexto medieval, além do valor de ensino, bem como preceito e doutrina associados ao âmbito gramatical, havia também o valor jurídico, em que o documento era sinônimo de prova e testemunho (LOPEZ YEPEZ, 1978). No século XIII, associado à ideia de educação, assumiu também o valor de "modelo", "leitura" e "demonstração", ou seja, tudo aquilo que pode ser remetido à "instrução". Tais significados perduraram até o século XVII, quando o termo ganhou um novo status no contexto burocrático estatal como "informação", "evidência" e "matéria de prova", assumindo importante papel no âmbito do Direto, na elaboração de leis, e na Diplomática e Arquivística, quando se relaciona à autenticidade e à prova documental, além do valor de caráter histórico.

No século XVIII, com o desenvolvimento da esfera pública, cresceu sua importância, motivada pelo aumento nas pesquisas científicas que, ao exigirem provas empíricas, abriram outra perspectiva de significado para o termo. Porém, mesmo com tal potencial, foi só no século XIX, influenciado pela perspectiva das Ciências Humanas e do contexto positivista/iluminista, que se organizou um ramo do saber voltado ao documento, a Documentação (LUND, 2009). 
Para Ortega (2004), até o final do XIX, Biblioteconomia e Documentação compartilhavam necessidades, processos e instrumentos comuns. Porém, com a Revolução Industrial houve a necessidade de "capacitar" a massa de trabalhadores no sentido de torná-los alfabetizados e especializados tecnicamente. Para isso a Biblioteconomia teve que desviar sua atenção dos processos de análise e representação das unidades do conhecimento registrado para voltar-se ao movimento de criação e disseminação das bibliotecas públicas. Com isso, se instaura uma primeira cisão entre Biblioteconomia e Documentação, principalmente na Inglaterra e EUA.

Enquanto isso, as atividades da Documentação desenvolveram-se simultaneamente ao surgimento das bibliotecas públicas. Mas no início do século XX, a sistematização da Documentação proposta por Otlet e La Fontaine e a ampliação da noção de bibliografia, levou a um maior afastamento entre ela e a Biblioteconomia (ORTEGA, 2004). Segundo Shera (1980 citado por ORTEGA, 2004) esse fenômeno de afastamento de duas ocupações até então próximas é explicado pelo fato de que ao se diferenciarem do outro grupo, principalmente por uma mudança terminológica, procurando com isso se afirmarem, demonstrando que se ocupam de algo novo, mas de reconhecida dignidade e valor científico.

Além da sistematização da Documentação, Otlet teve importante papel na definição do termo "documento", definição que desenvolveu em sua obra clássica, o Traité de Documentation (1934). Nesta obra o autor enuncia de forma revolucionária para o período a ideia de documento. Primeiramente, parte de um termo genérico, biblion, cujo significado é associado a uma unidade intelectual e abstrata, que poderia ser representada concretamente em modalidades diversas (revistas, filmes, livros, etc). Dentre tais modalidades destaca-se o livro, suporte de certa matéria e dimensão em que se incluem signos representativos de certos dados intelectuais. Todavia, tanto o livro como o biblion, trazem em suas raízes etimológicas referências diretas ao livro, o que para o autor limitaria a noção a uma tipologia documental.

Diante disso, Otlet propõe o uso da palavra documento, que por ser mais abrangente, poderia representar qualquer coisa em que o conhecimento pudesse ser registrado, reconhecendo-se em seu bojo alguma propriedade informativa. Segundo Rabello (2009), tal acepção otletiana, ao ser concebida numa época de influência positivista, considerou a ação humana de agregar ao objeto uma função informativa, o que garantiu um status de objetividade ao termo. Logo, o que interessaria no documento não seria seu conteúdo cognitivo em si, mas o que fosse projetado nele. Nesse aspecto, 
o documento teria um importante papel na projeção de memória gráfica, auxiliando na preservação da memória da humanidade, o que corroboraria os intuitos pacifistas e universalistas de Otlet.

Além de o documento assumir um papel central no ideário pacifista, Otlet ainda esmiúça suas diferentes nuances. Diz, por exemplo, que em todo documento devem ser consideradas três ordens de elementos: os materiais (substância, forma, acabamento), os elementos gráficos (textos, imagens reais ou convencionais), e os elementos intelectuais, que segundo ele seriam os mais importantes, mas estariam vinculados aos dois primeiros. Assim, concluía que o documento era o resultado de múltiplas operações e combinações, sendo aproveitado em sua elaboração todos os estágios anteriores, além dos novos, formando assim uma cadeia de elos interdependentes e solidários (OTLET, 1934).

A noção de documento encetada por Otlet foi consolidada por seus discípulos, especialmente os franceses, responsáveis por disseminar o estudo da Documentação na Europa, que teve seu apogeu na primeira metade do século XX. Durante a Segunda Guerra Mundial passou por relativo esquecimento e foi retomada, principalmente na França pela funcionária da Biblioteca Nacional, Suzanne Briet. Enquanto isso, nos EUA e nos países influenciados por ele, difundiu-se a Ciência da Informação, colocando-se de lado o estudo da Documentação (ORTEGA, 2009b).

\subsubsection{Noções do termo informação}

O termo “informação", segundo Kornwachs e Konstantin (1996), tem origens gregas e latinas. Os termos gregos eidos/Idea, morphé e typos, usados na filosofia de Platão e Aristóteles, já traziam em seu bojo os conceitos-chave da ontologia e epistemologia grega, remetendo seu significado a "modelo" e "representação". No entanto, as raízes etimológicas do termo são latinas, provenientes dos termos informo e informatio, que denotavam o ato de moldar a mente ou de comunicar conhecimento.

Na Idade Média, influenciado pela filosofia escolástica, o sentido dos termos informatio e informo ganharam outras nuances. Além da herança latina, incorporou-se ao significado dos termos um uso moral e pedagógico, referindo-se à formação ou modelagem da mente, do caráter, ou mesmo seu treinamento ou instrução (CAPURRO; HJORLAND, 2007). Todavia, com a Idade Moderna, o uso dos termos se transformou 
novamente, perdendo suas conotações ontológicas e adquirindo um significado predominantemente epistemológico, associando-se à noção de informação o conceito de representação, introduzindo o termo no contexto do conhecimento e da linguagem (GONZALÉZ DE GOMES, 2002).

Um pensador do período moderno que trata indiretamente do termo informação é Descartes. Para ele, as ideias seriam formas de pensamento já que informavam ao cérebro sobre as coisas reais do mundo, funcionando assim como uma representação. Diferente da visão escolástica que enxergava o intelecto e a natureza como elementos em comunhão imediata, na visão racionalista e empirista moderna entre tais elementos haveria a "ideia", o que acarretava uma inversão de significado do termo informação. Segundo Capurro e Hjorland (2007):

A informação, de acordo com a visão global moderna mais geral, mudou de um cosmo ordenado divinamente para um sistema governado pelo movimento de corpúsculos. Sob a tutela do empirismo, a informação gradualmente moveu-se da estrutura para a essência, da forma para a substância, da ordem intelectual para os impulsos sensoriais. (CAPURRO; HJORLAND, p.159, 2007)

No entanto, um dos momentos de maior impacto na história do termo foi na segunda metade do século XX. O pós-guerra, a Teoria da Informação, Cibernética, a Teoria dos Sistemas, o nascimento da inteligência artificial, o desenvolvimento de tecnologias de informação e comunicação, além do surgimento de novas áreas do conhecimento foram fatores que redimensionaram o uso do termo "informação". Antes restrito a uma denominação abstrata, ganhou nesse conturbado contexto um status de conceito interdisciplinar (ROBREDO, 2005).

Como o termo informação ganhou uma versatilidade no contexto pós-moderno, acabou sendo usado por uma diversidade de disciplinas científicas, o que dificultou uma delimitação categórica do termo. Como exemplos de diferentes acepções temos a "naturalização" da informação, em que esta é considerada uma categoria antropológica referente ao fenômeno das relações entre as estruturas verticais e horizontais das mensagens humanas (KORNWACHS, KOSNTANTIN, 1996); ou mesmo a denotação do termo informação como "sinônimo de transmissão de sinais", conceito usado na Teoria Matemática da Comunicação, onde se excetuam seus aspectos semânticos.

De forma genérica podemos dizer que dos anos 50 até final da década de 60, houve uma tendência de se estudar o termo informação sob o viés das Ciências Duras, fato facilmente explicável pelo contexto histórico-social da época, marcado pela 
competição tecnológica bipolar entre EUA e URSS, desenvolvimento de novas tecnologias comunicacionais, bélicas e informacionais. A própria Ciência da Informação, que nasceu nesse período, teve como "padrinhos" profissionais das ciências exatas, engenheiros, físicos e matemáticos.

Impulsionada originalmente pelas ideias da Engenharia de Comunicação, teorias cibernéticas e sistemas de transmissão de sinais, que desenvolveram as bases para a caracterização dos modelos e processos de recuperação da informação (Information Retrieval), a Ciência da Informação também tomou como base elementos da Biblioteconomia Especializada e da Documentação. A partir de 1960 a Ciência da Informação se difundiu para outras áreas do conhecimento, o que acabou lhe dando diferentes contornos a cada perspectiva adotada (SIQUEIRA, 2010).

Gonzaléz de Gomes (2002), por exemplo, aponta três principais linhas de estudo da Ciência da Informação a partir da década de 1970: a linha das Ciências Cognitivas, da Linguística e das Ciências Sociais. Para a autora, a difusão da Ciência da Informação, principalmente no âmbito das Ciências Humanas, justifica-se pelo fato de várias disciplinas se consolidarem nesse período, e de certa forma influenciarem a "maneira de se enxergar" a informação nesses contextos. No âmbito das Ciências Cognitivas, por exemplo, a autora destaca a Psicologia, que entende a noção de informação como um elemento da esfera da cognição a partir dos estudos de Belkin (1991). Na perspectiva linguística, a autora destaca a visão de informação segundo Blair (1992), considerada sob a ótica da linguagem como sinônimo de produção de sentido; ou ainda, no âmbito social a autora destaca a perspectiva de Capurro (2007), que considera a informação como produto das ações de comunidades e práticas sociais.

Após esse período, nota-se uma proliferação do uso do termo informação em diferentes domínios. Se por um lado tal utilização demonstra o caráter interdisciplinar e polivalente do termo, por outro, tal "diversidade de acepções" exige um uso perspicaz considerando o aspecto contextual na delimitação do conceito. No caso especial da Ciência da Informação, no interior do qual para alguns autores o termo "informação" é o objeto do campo, a flutuação de significado é um fator que indica as dificuldades em se equacionar as oscilações e deslocamentos de sentido com a diversidade de usos na área.

Considerando essa diversidade de acepções dos termos "documento" e "informação", resultados da perspectiva interdisciplinar e heterogênea da atualidade, parece importante verificar as características próprias de cada termo e suas relações no 
âmbito da Ciência da Informação. Na tentativa de um delineamento mais perspicaz do campo da Ciência da Informação recorreremos à análise terminológica, a partir dos termos "documento" e "informação", utilizando essa metodologia para identificar os diferentes traços dos termos. Diferente da concepção da Terminologia Clássica, aqui será considerada principalmente a vertente contemporânea que está focada no contexto de uso das definições.

\subsubsection{O papel da Terminologia}

A Terminologia, como instrumento teórico e metodológico, fornece instrumental para identificar as nuances da área da Ciência da Informação sem deixar de observar as variações de uso e sua inserção histórico-cultural. Por meio da identificação de conceitos/noções, termos e definições inscritas nos discursos, é possível verificar as formas de constituição dos domínios, seu desenvolvimento, bem como as relações que estabelecem com domínios fronteiriços.

Nesse viés, segundo Lara (2008), a principal contribuição da Terminologia não é apenas a mera identificação dos termos, mas a "validação social das escolhas de forma e de conteúdo, como expressão pragmática da observação dos discursos das comunidades de uso". Dessa forma, as estruturas de organização da informação reproduzem os contextos histórico-culturais e suas transformações no tempo e no espaço (TÁLAMO, 2001).

A história da Terminologia, assim como sua concepção e utilização, está muito ligada a duas noções: a prática e a delimitação de uma área. Lineu (1707-1778) foi um dos precursores do estudo terminológico voltado às taxionomias. No século XIX e depois com o acelerado desenvolvimento técnico e científico do século XX, a Terminologia se consolidou cientificamente. Assim, a denominada "Terminologia Moderna" iniciou-se com os trabalhos de Lotte (1888-1950), da escola soviética, e de Wüster (1897-1977) da escola austríaca. O primeiro se detinha nos aspectos teóricos e metodológicos da Terminologia, encarando-a como disciplina científica influenciada pela Filosofia. O segundo, influenciado pela Lógica, se preocupava com o tratamento dos dados terminológicos e sua padronização, tomando a Terminologia como uma disciplina autônoma de caráter interdisciplinar, com função de atuar a serviço das demais disciplinas técnico-científicas (CABRÉ, 1993). 
No entanto, na atualidade, mesmo com a importância da herança da Escola de Viena para a delimitação dos pilares terminológicos, critica-se a ênfase normativa da Terminologia clássica. Na perspectiva contemporânea o termo não deve ficar restrito ao âmbito normativo, mas ser analisado em seus diferentes contextos discursivos, o que permite encontrar seu valor como uma unidade significativa de uma área na perspectiva do uso.

A partir desse pressuposto, podem-se destacar os seguintes estudos contemporâneos da Terminologia: a Teoria Comunicativa da Terminologia, fruto dos trabalhos de Cabré e seus colaboradores do IULA (Instituto de Linguística Aplicada da Universidade Pompeu Fabra, em Barcelona) na Espanha; a Socioterminologia, com os trabalhos de Gaudin (França) e Auger (Canadá); a Terminologia Cultural com DikiKidiri (Senegal); a Terminologia Cognitiva com Temmerman (Alemanha), e ainda diversos trabalhos que se utilizam da Teoria do Discurso e da Linguística Textual, que procuram referências na Pragmática e na Semiótica (LARA, 2005).

Quanto ao termo "terminologia", deve-se considerar seu caráter polissêmico, logo, é necessário identificar sob qual aspecto estamos tratando o termo. Segundo Cabré (1999), há basicamente três noções para o termo: pode se referir a uma disciplina, ou seja, uma matéria que se ocupa de termos especializados; a uma prática, conjunto de princípios encaminhados à recopilação de termos; ou a um produto, conjunto de termos de determinada especialidade, gerado pela prática.

Considerando a Terminologia como uma disciplina teórica e aplicada, observase que envolve a descrição e o ordenamento do conhecimento, tanto num nível cognitivo como comunicacional, utilizando como elementos-chave conceitos e termos. Compreende o estudo científico dos conceitos e seus respectivos termos considerando seu funcionamento social e sua inter-relação com outras áreas, já que também se constitui como um campo inter e transdisciplinar (CABRÉ, 1999).

Para a autora, o contexto interdisciplinar considera que a Terminologia, para descrever seu objeto, precisa de outras disciplinas (Ciências da Linguagem, Comunicação e Ciências Cognitivas). Já no âmbito transdisciplinar muda-se o enfoque, ou seja, é a Terminologia que participa da constituição de diversas matérias de especialidade, considerando que não se faz ciência sem o aporte terminológico.

A produção do conhecimento científico se constitui a partir de um tripé epistemológico: a delimitação de um campo de conhecimento, uma metodologia adequada à pesquisa, e uma terminologia própria. No contexto movediço da 
contemporaneidade, em que convivem referências modernas e pós-modernas, os estudos terminológicos facilitam a delimitação de campos de conhecimento e a identificação de conjuntos de termos próprios de um domínio.

Dessa forma, nota-se que a Terminologia se converte tematicamente como base para a estrutura do conhecimento especializado. No lugar de estruturas fixas e unidirecionais que refletiriam uma organização disciplinar, destaca-se o uso, a partir do qual são incorporados o dinamismo e as inter-relações disciplinares. Considerando tal dimensão, pode-se destacar como exemplo a utilização da Terminologia na Ciência da Informação.

A Ciência da Informação, fruto do contexto pós-moderno, é uma área que mesmo com considerável desenvolvimento e nítida aplicação em diferentes esferas do conhecimento, não está claramente consolidada. Diante desse cenário, a Terminologia surge como uma possibilidade para a busca de traços que permitam melhor delinear o campo da Ciência da Informação.

\subsection{Metodologia}

\subsubsection{Objeto de estudo}

Identificar traços que auxiliem o delineamento do campo da Ciência da Informação a partir da análise terminológica das noções de "documento" e "informação".

\subsubsection{Opções metodológicas}

A opção pela pesquisa terminológica visou a melhor análise e sistematização das características dos termos selecionados. Os objetivos da pesquisa são de caráter explicativo, uma vez que se procura compreender os aspectos que mais caracterizam a Ciência da Informação como campo de estudos e de aplicação a partir da descrição e observação dos termos utilizados em sua literatura.

Primeiramente foi feita a revisão bibliográfica, com intuito de: compreender o escopo do domínio da Ciência da Informação; observar os aspectos relevantes da Terminologia que corroboram o delineamento do campo da Ciência da Informação; e posteriormente, recuperar as principais noções sobre os termos documento e informação. Num segundo momento foi feita a pesquisa aplicada, utilizando-se as técnicas da análise terminográfica, para analisar e propor sínteses definitórias dos termos em questão. 


\subsubsection{Procedimentos}

Partiu-se do princípio que a Terminologia tem instrumental para identificar os conceitos, termos e sua organização sistêmica em domínios. Se do ponto de vista teórico a Terminologia oferece princípios para a análise terminológica, do ponto de vista do método, a Terminografia oferece ferramentas concretas para o desenvolvimento do trabalho.

A primeira fase da pesquisa voltou-se ao levantamento bibliográfico para a construção do corpus: o corpus de trabalho propriamente dito e o corpus de apoio. Selecionados, iniciou-se a segunda fase do trabalho que se constituiu da leitura e coleta de termos, quando foram utilizados procedimentos terminográficos para o preenchimento de fichas terminológicas de cada termo. A terceira fase compreendeu a análise terminológica propriamente dita, com a separação das características ou atributos dos termos e sua comparação utilizando fichas terminológicas de síntese. E a partir das sínteses foi possível verificar as relações entre os termos e de que forma corroboram o escopo da Ciência da Informação.

O levantamento bibliográfico foi realizado em quatro etapas: a consulta dos termos feita em dicionários da área; a busca de resumos na base LISA (Library Information Science Abstracts); pesquisa de autores feita a partir da bibliografia sugerida na disciplina de "Informação e Cultura" e pesquisa nas bases de textos completos do Portal Capes. A primeira etapa teve como objetivo ter uma noção inicial da definição dos termos, constituindo o corpus de apoio. Foram consultados cinco dicionários da área: Dictionaire encyclopedique de l'information et de la documentation (CACALY; LE COADIC, 2001); Diccionario técnico de biblioteconomia españolinglés (MASSA DE GIL; TRAUTMAN, GOY, 1964); Dicionário de Biblioteconomia e Arquivologia (CUNHA, CAVALCANTI, 2009); Dicionário do livro (FARIA; PERICAO, 2009) e Dicionário eletrônico de terminologia da Ciência da InformaçãoDeltci $^{1}$ (2007). Nesse levantamento, além de identificar as perspectivas conceituais dos termos selecionados, foi possível também, principalmente na obra de Cunha e Cavalcanti (2009), verificar alguns autores referenciais da área, pois nesse dicionário além das acepções nos verbetes, há uma preocupação em destacar as fontes de suas definições, autoria e ano de publicação. Contudo, a função dessa primeira etapa foi

\footnotetext{
${ }^{1}$ Deltci disponível em: www.ccje.ufes.br/arquvologia/deltci.
} 
apenas uma sondagem inicial dos termos, não sendo recuperada nem na revisão bibliográfica nem na análise terminológica.

A segunda etapa, a busca de resumos na base LISA (Library Information Science Abstracts), teve como objetivo fazer um primeiro mapeamento de possíveis textos que serviriam para o corpus de trabalho. Para isso foi necessário realizar uma busca avançada utilizando como palavras-chave os termos "documento" e "informação", buscados como assunto e também como parte do título. Todavia, pela grande utilização desses termos na área os resultados obtidos foram pouco precisos. Além disso, o fato desses termos estarem presentes em diferentes temáticas da área, não se constitui em indicativo, apenas com a leitura do resumo, para saber se o autor faria a definição dos termos, ou os utilizaria de modo a fornecer traços para sua caracterização. O resultado obtido não foi satisfatório para uma primeira seleção do corpus de trabalho, sendo utilizado apenas como apoio.

Esse momento de impasse coincidiu com a época em que estávamos cursando a disciplina "Informação e Cultura" do Programa de Pós Graduação em Ciência da Informação, fato que contribuiu para dar um "norte à pesquisa". Nessa disciplina, dentre outras discussões sobre o escopo da Ciência da Informação, foram debatidos textos que tratavam sobre as noções de "documento" e "informação". Dentre vários autores podemos citar: Bush (1945), Buckland (1991), Wersig (1993), Saracevic (1995), Rayward (1997), Frohmann (2004), Capurro (2007) Lund (2009) e Ortega (2004; 2008; 2009abc; 2010). Todos esses autores foram incorporados à pesquisa, principalmente para compor o levantamento histórico-conceitual dos termos. O que definiu o papel de cada autor no trabalho foi a abrangência e a perspectiva desenvolvida em sua pesquisa, com destaque para Lund, Capurro e Ortega. Esses autores, além de contribuírem com a sua perspectiva sobre os termos "documento" e "informação", ofereceram um panorama histórico-conceitual dos termos, localizando-os no contexto da produção da área. Essa é a razão pela qual foram selecionados como "autores-chave" para a pesquisa.

Sobre os "autores-chave" é importante mencionar como cada um contribuiu ao escopo de nosso trabalho. Lund (2009), por exemplo, ao invés de fazer uma sucessão 
cronológica conceitual do termo documento, expos três linhas de estudo ${ }^{2}$ sobre o termo: a francesa, a espanhola e a anglo-escandinava. Mesmo com as inevitáveis distinções de olhares dos autores, é possível a partir dessa divisão, identificar proximidades entre os autores de uma mesma linha, fator talvez explicável pela influência do contexto histórico-cultural. Essa divisão também marca o trabalho de Ortega (2004; 2008; 2009abc; 2010). Assim, tanto para a revisão histórico-conceitual, como para a melhor organização do trabalho terminológico, foi utilizado esse critério para a reunião de autores presentes nas linhas de estudo francesa, espanhola e anglo-escandinava.

Capurro (2007), por sua vez, também não fez um mero levantamento cronológico do termo informação, já que reuniu os autores a partir da perspectiva de seus três paradigmas de informação: o físico, o cognitivo e o social. Essa noção dos três paradigmas foi desenvolvida pelo autor no texto Epistemologia da Ciência da Informação (2003), e recuperada e expandida, em seu artigo com Hjorland em 2007 sobre o conceito da informação, tornado-se uma obra referencial para a área. Capurro expõe para o termo informação, assim como Lund para o termo documento, um relevante panorama dos autores e suas principais vertentes de estudo, o que é recuperado aqui neste trabalho na revisão de literatura. Além disso, para a análise terminológica são aproveitadas as referências bibliográficas desses dois autores por sua amplitude e variedade.

A produção de Ortega (2004; 2008; 2009abc; 2010), por sua vez, constituiu referencial importante para conhecer melhor a produção em língua francesa e espanhola, já que esses autores são menos citados do que os anglo-escandinavos na literatura de Lund e Capurro. Tais trabalhos contemplam mais especificadamente o termo documento a partir do qual a autora ressalta, como embrião, a noção de informação. Essa produção foi essencial para consolidar o panorama histórico conceitual, bem como completar a seleção terminológica.

Nesse momento iniciou-se a quarta etapa, a busca pelos autores referenciados por Lund, Capurro e Ortega. Nesse levantamento optou-se tanto por materiais impressos (livros e artigos) como pela consulta às bases do Portal de Periódicos da Capes.

\footnotetext{
${ }^{2}$ A menção de "três linhas de estudo" é feita com base nas afirmações dos próprios autores, mas tem como ressalva considerar que tal perspectiva é fruto da visão Ocidental, já que pouco é difundido e conhecido do estudo dos orientais sobre tal temática.
} 
Diferentemente da busca feita na base LISA inicialmente, nesta etapa foram selecionadas apenas bases de textos completos, como por exemplo, a Emerald fulltext, Elsevier Science, Scopus e Annual Review of Information Science and Technology. Na busca, além dos termos "documento" e "informação", foram acrescidos nomes dos autores e títulos das obras, o que permitiu chegar a um resultado mais preciso. Dessa forma, grande parte dos textos utilizados na revisão histórico-conceitual, como aqueles selecionados para a análise terminológica foram encontrados nesse momento, sendo acrescidas posteriormente, de algumas sugestões bibliográficas feitas pela banca na qualificação.

$\mathrm{Na}$ fase de análise terminológica foi considerada a vertente da Teoria Comunicativa da Terminologia, representada por Cabré e seus colaboradores do IULA. Um dos diferenciais dessa perspectiva contemporânea é verificar que o termo não deve ficar restrito ao âmbito normativo - visão da Terminologia clássica -, mas deve ser analisado em seus diferentes contextos discursivos. Dessa forma o termo encontra seu valor como uma unidade significativa de uma área na perspectiva do uso, ressaltando assim o aspecto contextual.

Quanto à análise terminológica propriamente dita, para os procedimentos de coleta e registro dos termos em fichas terminográficas, foram combinadas as sugestões de duas autoras: Cabré e Barros. Barros (2004) fala de dois tipos de ficha, as de referências e as terminológicas, sendo que esta última se subdivide em: ficha de trabalho, síntese e remissiva. Para Cabré (1993) há três tipos de materiais: os de consulta, os destinados especificamente ao trabalho terminográfico e os de suporte, sendo este último subdividido em: fichas de coleta, terminológica, de correspondência e de consulta. Nesse trabalho são usadas basicamente as fichas de coleta de termos, de análise e síntese.

$\mathrm{Na}$ ficha de coleta foram considerados os seguintes elementos: identificação do termo, idioma, fonte do termo e contexto. Na ficha de análise, além dos elementos anteriores, foi feita a apreciação do contexto, analisando suas partes seccionadas em características, sintetizadas pelas entradas: perspectiva objetiva, perspectiva subjetiva e perspectiva social. E por fim na ficha de síntese, a partir do quadro relacional entre os diferentes contextos selecionados, foi elaborada uma proposta de definição que procurou sintetizar as principais características analisadas de cada termo. A partir das sínteses das noções foi possível verificar as principais aproximações e distinções entre 
esses dois termos, bem como sua contribuição ao delineamento do campo da Ciência da Informação.

\subsection{Organização da dissertação}

No primeiro capítulo, Ciência da Informação: das origens aos dias de hoje, apresenta-se um pouco da história e das características dos modelos de produção do conhecimento que influenciaram o surgimento e o desenvolvimento da Ciência da Informação. O objetivo do capítulo é entender o contexto de criação e desenvolvimento da Ciência da Informação, a fim de melhor compreender, posteriormente, os elementos que contribuem fortemente à delimitação do campo, ou seja, as noções de "documento" e "informação".

No capítulo seguinte, Os estudos terminológicos e a Ciência da Informação, considera-se a relevância do estudo terminológico na delimitação do escopo da Ciência da Informação, sendo feita uma revisão de literatura sobre a Terminologia. A revisão aborda desde um breve panorama histórico, destacando as principais vertentes de atuação, à conceituação da disciplina, incluindo a discussão de seu aspecto interdisciplinar. Além disso, são apresentados alguns fundamentos teóricos terminológicos que foram utilizados na análise terminográfica.

No terceiro capítulo, Revisão de literatura dos termos "documento" $e$ "informação", retomam-se as principais noções dos termos. O intuito do capítulo é traçar uma visão panorâmica das principais acepções dos termos, no âmbito do recorte cronológico e da cobertura temática elegida, a fim de constituir a base comparativa para a análise terminológica.

No quarto capítulo, Noções dos termos "documento" e "informação”: análise terminológica, realizamos a análise terminológica propriamente dita. Nesse capítulo apresenta-se o percurso terminológico, começando pela apresentação das definições selecionadas na ficha de coleta, seguidas de um quadro comparativo dos traços encontrados em cada noção, seguindo-se a apresentação da síntese definicional de cada termo.

E no capítulo quinto, Resultados da análise dos termos documento e informação, a partir das sínteses das noções documento e informação, são elencadas as principais aproximações e distinções entre esses dois termos, com destaque para o modo como podem contribuir para o delineamento do campo da Ciência da Informação. 


\section{Capítulo - Ciência da Informação: das origens aos dias de hoje}

\subsection{Introdução}

Nos últimos anos houve relativo avanço nos estudos no domínio da Ciência da Informação. Todavia há ainda obstáculos que obliteram a constituição da área como campo científico. Verificar seu caráter como prática científica é notório, porém reconhecer o pensamento que a constitui é difícil, já que se esbarra em terminologias oriundas de diferentes disciplinas, além do fato do fato da conjuntura histórico-social ser caracterizada pela transição de modelos de produção científica do conhecimento (TÁLAMO; SMIT, 2007).

Se por um lado a Ciência da Informação ainda é fortemente influenciada pelo modelo de ciência moderna, alicerçada numa visão racionalista, funcionalista e voltada à especialização do saber, por outro lado, ela "nasce" num momento de emergência do paradigma pós-moderno, de natureza subjetiva, interdisciplinar e voltada a problemas e não às disciplinas. Assim, os parâmetros modernos, tradicionalmente considerados elementos chave para a constituição de uma área, agora se desestabilizam, a exemplo da definição do objeto das ciências, sua metodologia e sua terminologia.

A noção de um objeto no âmbito pós-moderno se relativiliza, não sendo mais o epicentro do olhar científico, mas um filtro adotado para problematizar os elementos do mundo, ou seja, adquire uma função de ponto de vista (TÁLAMO; SMIT, 2007). Apoiadas em Santos (1987), as mesmas autoras salientam que, diferentemente da fragmentação moderna, de caráter disciplinar, vivemos um momento de transgressão metodológica, em que a fragmentação é temática, ou seja, "cada método é uma linguagem e a realidade responde na língua em que é perguntada" (SANTOS, 1987, p.48). Também segundo as autoras, a identificação do domínio da Ciência da Informação esbarra em terminologias que correspondem a distintos momentos históricos da produção do conhecimento, sendo elas muitas vezes incompatíveis. Muitas alterações nem sempre são percebidas no momento em que ocorrem, além do fato de que seu entendimento na contemporaneidade "exige uma atitude científica que não se deixe envolver por tipologias que, embora ainda gozem de certo prestígio, não conduzem a um entendimento da complexidade do campo dos processos de construção e circulação da informação" (TÁLAMO; SMIT, 2007). 
Diante de tais transformações é relevante conhecer um pouco da história e das características de cada modelo de produção do conhecimento que influencia a Ciência da Informação. O objetivo desse capítulo é, portanto entender o contexto de criação e desenvolvimento da Ciência da Informação, a fim de melhor compreender posteriormente, nos outros capítulos, elementos constituintes do campo, as noções de “documento" e "informação".

\subsection{Ciência da Informação: história e indagações}

As origens dos estudos informacionais e comunicacionais, segundo Simeão (2006) remonta aos escritos de Aristóteles, filósofo da Grécia Antiga, que já trazia em suas pesquisas aspectos da transmissão da informação, mesmo que por uma perspectiva filosófica. Depois disso, foi só no século XVIII, com o movimento enciclopedista francês, que a ideia de informação ressurgiu com uma nova roupagem, entendida como um elemento integrante do sistema de comunicação e assumindo um caráter mais científico e conceitual. Porém, foi apenas no século XIX que a comunicação e a informação foram percebidas como fenômenos sociais, fruto das transformações socioculturais e tecnológicas do período.

Tal percepção do papel da comunicação e da informação foi acentuada na revolução científica e técnica da segunda metade do século XX, pós-segunda Guerra Mundial. Para muitos autores esse seria o marco inicial dos estudos informacionais, como conhecemos hoje (SIMEÃO, 2006). Para entender como tal momento histórico influenciou as "raízes" da Ciência da Informação, é interessante contrapor o contexto antecedente versus o precedente a tal marco.

Na transição do século XVIII para o século XIX, Estado e Igreja se separaram. O homem, numa postura cada vez mais autônoma, ampliava sua visão de mundo a partir do desenvolvimento científico, tecnológico e artístico, influenciado pelo olhar racionalista e pragmático do momento. O pensamento filosófico da época foi marcado por figuras e correntes como: Johan Gottlib e o Idealismo alemão; Karl Marx e o materialismo histórico; Friedrich Engels e o Hegelianismo; Auguste Comte e o Positivismo; Charles Sanders Peirce e John Stuart Mill com o Pragmatismo; Ferdinand Saussure e o Estruturalismo linguístico; Gottlob Frege e a Lógica formal; e o visionário Friedrich Nietzsche criticando o Iluminismo (ROBREDO, 2007). 
Esse modelo de racionalidade que inicialmente dominou as ciências naturais até o século XVIII, no século XIX se estendeu às ciências sociais emergentes e influenciou o pensamento científico até o início do século XX (SANTOS, 1987). Tal modelo priorizava a funcionalidade e a utilidade do conhecimento, naturalizando a explicação do real. Essa naturalização promoveu o distanciamento do sujeito frente ao objeto, o que marcou a objetividade do conhecimento. Além disso, alicerçada na especialização do saber, a naturalização do real delimitou nossa visão de mundo em categorias de tempo, espaço, matéria e número (TÁLAMO; SMIT, 2007).

Verifica-se, assim, que a informação até o início do século XX tinha uma função utilitarista. Na $1^{a}$ Guerra Mundial (1914-1918) tal papel começa a mudar, marcada por três principais tendências: uma de revolução, a exemplo da Rússia marxista; outra de crise, a exemplo da depressão econômica e das interguerras civis; outra, ainda, correspondente à Belle Époque, vivida pelos países vitoriosos, principalmente EUA. No conjunto, observa-se o crescimento de uma necessidade informacional no seio da sociedade (ROBREDO, 2007).

A importância da informação como necessidade se consolida na $2^{\mathrm{a}}$ Guerra Mundial. Num cenário de rupturas e descontinuidades trazido pela guerra, questões como o acesso, a recepção e a adaptabilidade das diferentes necessidades sociais tornam-se elementos importantes para se pensar a informação (TÁLAMO; SMIT, 2007).

Com o fim da $2^{\mathrm{a}}$ Guerra Mundial diversas revoluções se instauraram, tanto de natureza socioeconômica, a exemplo da divisão bipolar do mundo entre EUA e URSS, como tecnológica e comunicacional, a exemplo do computador e as redes de satélites. No que tange à Ciência da Informação, além do contexto histórico-social propício para o desenvolvimento de novas ciências com interfaces com outras áreas, teve sua origem motivada pela necessidade de resolver o problema da organização e do acesso ao conhecimento científico, cultural e tecnológico, que crescia desordenada e geometricamente (LILLEY;TRICE 1989).

Impulsionada originalmente pelas ideias da engenharia de comunicação, teorias cibernéticas e sistemas de transmissão de sinais, que desenvolveram as bases para a caracterização dos modelos e processos de recuperação da informação (Information Retrieval), a Ciência da Informação também tomou como base elementos da 
Biblioteconomia Especializada e da Documentação. Enquanto a Biblioteconomia Especializada estava muito atrelada aos aspectos sociológicos (herança da Escola de Chicago, 1930) e institucionais, a Documentação foi praticamente substituída nos EUA pela Ciência da Informação, difundindo-se também pela Europa (OLIVEIRA; ARAÚJO, 2002).

Na Europa, a Documentação também incorporou as noções de automatização de serviços e técnicas, além de uma perspectiva de informação científica preocupada com o acesso e a recuperação, desenvolvendo importantes centros de documentação (ORTEGA, 2009a). Enquanto isso, EUA e URSS, numa competição antes de tudo ideológica, ao incorporarem as inovações tecnológicas e científicas, sentiram a necessidade de demonstrarem seu poderio, denominando através dos campos responsáveis pelo tratamento e difusão da informação, sua perspectiva de mundo, “Ciência da informação" nos EUA e "Informatika” na URSS (BARRETO, 2007).

Dessa forma, pode-se constatar que nesse período inicial, a Ciência da Informação, ainda muito ligada à Documentação e Biblioteconomia, teve grande parte de seu instrumental voltado à recuperação informacional e maior precisão nas buscas. Foi a "era das classificações", tesauros e indexações e de dispositivos como as bases de dados. Outras importantes mudanças também marcaram o denominado "período de gerência" (1945-1980): o aparecimento de novos profissionais, não só provenientes da Biblioteconomia, mas de diferentes áreas, em especial das ciências duras, para compor o corpo profissional da Ciência da Informação; o aparecimento de agências de pesquisa, patrocinadas pelo Estado ou por empresas privadas, que desenvolveram importantes projetos e serviços especializados; e o surgimento de uma comunidade científica responsável por eventos e publicações, fatores que corroboraram a consolidação da área (BARRETO, 2007).

Num segundo momento, o tempo da relação "informação e conhecimento" (1980-1995), o foco passa a ser a ação da informação na coletividade, ou seja, consideram-se quais seriam as melhores formas da passagem da informação para os receptores, ponderando o bem estar e as competências do indivíduo para interiorizar a informação (BARRETO, 2007). A distinção entre o período da gerência e o da relação informação e conhecimento, enunciados por Barreto (2007), pode ser facilmente 
observada ao se contrapor duas conceituações da área, a partir da visão de autores de cada período:

A Ciência da Informação investiga as propriedades e o comportamento da informação, as forças que governam seu fluxo e os meios de processamento para otimizar sua acessibilidade e utilização.Relaciona-se com o corpo de conhecimento relativo à produção, coleta, organização, armazenagem, recuperação, interpretação, transmissão, transformação e utilização da informação (BORKO, p.13, 1968).

Campo científico dedicado a questões científicas e à prática profissional, voltada para os problemas de efetiva comunicação do conhecimento e de registros de conhecimento entre seres humanos, no contexto social, institucional do uso das necessidades de informação (SARACEVIC, p.47, 1995).

A primeira conceituação corresponde ao tempo da gerência, por trazer elementos que reforçam o problema-chave desse período: a organização, recuperação e acesso à informação. Podem-se notar ainda expressões que denotam outras importantes influências da época como os termos "fluxo" e "meios de processamento", que indicam a influência da Teoria de Informação (Shannon e Weaver, 1945), Informática e até as Ciências Cognitivas, mais voltadas aos aspectos físico ou cognitivo da informação; ou mesmo associando a Ciência da Informação a diversas ações referentes à recuperação e uso da informação, aproximando-a das telecomunicações.

Já a segunda conceituação, mesmo trazendo alguns indícios do primeiro momento, está focalizada na "comunicação do conhecimento", voltando-se, ao contrário da primeira, às necessidades de informação, considerando para isso não só os recursos em si, mas o contexto social e/ou institucional. Assim, numa perspectiva mais influenciada pelos aspectos sociais, Saracevic (1995) propõe para Ciência da Informação um papel a desempenhar dentro de determinado contexto, ressaltando seu caráter interdisciplinar e questionando os imperativos tecnológicos e o comportamento de seu suposto objeto, a informação, presente nas diferentes perspectivas comunicacionais e científicas.

Quanto ao último momento, o "tempo do conhecimento interativo", entra em cena a Internet, que aproximadamente a partir de 1995, somada às novas tecnologias de comunicação, são responsáveis por importantes mudanças na área. A ideia de tempo e espaço, por exemplo, perspectiva à época estanque e mais controlável, toma outra dimensão com o recurso da web, mudando a relação informacional, não mais 
bidimensional (emissor-receptor), mas pluridiversa, fundindo sujeito/objeto num dinâmico contexto interativo de trocas (BARRETO, 2007).

Nessa perspectiva, autores como Wersig (1991), consideram a Ciência da Informação como uma ciência pós-moderna, não mais voltada a um entendimento completo de um objeto, mas procurando desenvolver estratégias para resolução de problemas. O autor a define como um conjunto de modelos desenvolvidos sob o ponto de vista do problema do uso do conhecimento a partir das condições pós-modernas da informação.

Dessa forma, com uma "identidade nebulosa" e influenciada pelas fragmentações do fim do século $\mathrm{XX}$, ocorre a incessante tentativa da Ciência da Informação de sedimentar seu estatuto científico e social. No entanto, para galgar tal estatuto depende da operacionalização de seus objetos, teorias e metodologias.

Mas será que a Ciência da Informação, por ter nascido nesse contexto de rupturas, pode ser encarada como uma "personagem” da pós-modernidade? Qual será a melhor forma para responder às questões informacionais apresentadas pela sociedade: formatando-se aos moldes disciplinares, ou procurando resolver os problemas da pósmodernidade? Na tentativa de entender tal dilema, propomo-nos a verificar quais são as principais características e relações entre os modelos moderno e pós-moderno, bem como compreender o papel da Ciência da Informação nesse contexto.

\subsection{As nuances do paradigma moderno e do pós-moderno}

A crise do paradigma moderno, segundo Santos (1987, p.24), é "resultado interativo de uma pluralidade de condições". Fatores históricos e socioculturais se amalgamam para constituir seu colapso. Com Einstein, por exemplo, temos um marco para o surgimento do novo paradigma, a ideia de relatividade e simultaneidade, conceitos que não se restringiram ao contexto da física quântica e que se dissiparam em nosso cotidiano. As leis ganharam um caráter probabilístico, aproximativo e provisório, já que até as ciências duras passaram por um momento de pluralidade de métodos e relativização de conceitos. Quanto à simultaneidade, podemos ver a mudança nas relações comunicacionais, transformadas pelos aparatos tecnológicos interativos da $w e b$, bem como pela superação das dicotomias sujeito/objeto e tempo/espaço. 
Para entender as diferenças entre o modelo moderno e o pós-moderno, é interessante retomar o contexto medieval, que se por um lado foi um período de gestação do Mundo Moderno, por outro tem aspectos que poderiam ser revisitados na contemporaneidade. Na Idade Média, por exemplo, filosofia e religião teciam uma íntima relação, diversas seitas judaicas, cristãs, cultos pagãos, gnósticos e herméticos competiam por adeptos, ao mesmo tempo em que muitos desses religiosos eram importantes filósofos: platonistas, aristotélicos, epicuristas e estoicos (COOPER, 2002). Tal proximidade poderia ser rotulada como "controversa", mas já revelava algo comum à contemporaneidade com a aproximação de elementos supostamente "díspares", mas que em determinado momento e contexto se relacionavam.

Para Cooper, o conhecimento na época subdividia-se em duas categorias: aquele estabelecido pela minoria de letrados, em grande parte religiosos, que constituíam os professores das primeiras universidades e que monopolizavam o saber da Filosofia e da Teologia; e os saberes populares transmitidos oralmente, tais como os dos artesãos, camponeses, parteiras, etc. Enquanto o saber no primeiro caso percorria concomitantemente duas vias, da fé e da razão, no segundo caso aliava técnica e tradição, já que além de significar uma atividade para subsistência, também representava o conhecimento de um povo (COOPER, 2002).

A noção de coletivo na Idade Média é outra questão muitas vezes desconsiderada para os olhares "disciplinados" modernos, e até ignorada na perspectiva multifacetada da contemporaneidade. Congregados pelo apelo religioso, a partir do século $\mathrm{X}$, os homens medievais acreditavam serem capazes de constituir um povo único, uma entidade que pretendia espelhar e prefigurar sua religião, a partir de um sentido da transcendência que arrancava o indivíduo da sua condição particular e o impulsionava a uma capacidade de agir e pensar em conjunto (COOPER, 2002).

A perspectiva medieval, aos poucos influenciada pelo Humanismo, foi transformando a visão do homem ocidental na Baixa Idade Média. O surgimento da ciência, por exemplo, não gerou de imediato um divórcio com a religião, já que os primeiros cientistas eram religiosos. As universidades da época, mesmo formando os primeiros letrados modernos, ainda eram espaços voltados à transmissão de saber e não à sua descoberta, onde opiniões e interpretações de grandes pensadores não podiam ser refutadas (BURKE, 2003). 
Segundo Burke (2003), o período moderno seria definido como os séculos de Gutenberg e Diderot. O primeiro reconhecido pelo surgimento da impressa na Europa a partir de 1450; e o outro pela edição da Encyclopédie (1750-1772), marcos do início do mundo moderno por contribuírem com a difusão e organização do conhecimento. Quanto ao contexto de surgimento da modernidade, Bauman (2001) ressalta o momento em que o espaço e o tempo foram separados da prática da vida e entre si. Ao contrário dos séculos anteriores em que havia uma relação biunívoca entre eles, a partir da modernidade o tempo e o espaço poderiam ser teorizados como categorias distintas e mutuamente independentes.

No século XVII, com o Iluminismo, a religião se desvincula do Estado, e com isso a fonte do conhecimento passa a ser a razão e a experiência (empirismo) baseadas no desenvolvimento científico. O Projeto das Luzes volta-se aos princípios da razão e do questionamento crítico em busca da verdade, autonomia, e das escolhas a partir da ruptura com o senso comum, a fim de desenvolver um modelo científico (BAUMAN, 2001).

As primeiras manifestações iluministas tentavam resolver as incertezas provenientes da crença de que o homem poderia apreender as forças e manifestações da natureza física, biológica ou social através do pensamento. Assim, com o fenômeno da Revolução Científica, ocorre a incorporação de conhecimentos antes considerados "alternativos" ao saber estabelecido, o que corrobora a organização disciplinar do saber. Tal abordagem contribuiu com a criação das organizações e sociedades científicas, espaços voltados à pesquisa e que estimulavam a figura dos pesquisadores profissionais. O desenvolvimento científico ganhou maior espaço no século XVIII, com o aumento da necessidade de conhecimento da humanidade e também influenciado pelos princípios iluministas, calcados na razão e na busca por verdade (BURKE, 2003).

A promessa da racionalidade e progresso contida na acepção científica se difundiu a partir de um modelo disciplinar em que o conhecimento se legitimou. A ideia de busca pela verdade, diante dos distintos fenômenos da realidade, se estabeleceu mediante a divisão de um objeto em diversas partes, podendo estas serem investigadas por um método analítico, e assim conhecidas. Nesta perspectiva, segundo Morin (1997), os fenômenos físicos e sociais poderiam ser decompostos em diversas partes a fim de 
serem analisados e somente aí compreendidos no contexto disciplinar, portanto, nessa perspectiva, o conhecimento seria sinônimo de separação.

O desenvolvimento do conhecimento no mundo ocidental moderno foi consolidado pelo modelo da racionalidade científica e técnica que passou a exercer supremacia nos territórios de nossa cultura. A decomposição dos objetos em partes trouxe importantes contribuições acerca da compreensão das particularidades, o que de certa forma favoreceu a organização do conhecimento. Ao separar sujeito e objeto numa ação disjuntiva negou-se o fluxo de suas inter-relações, limitando os processos de construção do conhecimento, ao mesmo tempo em que superestimou a especialização em áreas isoladas que muitas vezes desconsideraram as esferas do real e seus fenômenos físico-naturais aos socioculturais (ARAÚJO, 2000). Tal modelo disciplinar "separatista" acabou por desvincular o conhecimento da "sinuosidade" que perfaz a vida cotidiana, constituída de teorias abstratas, complexas e paradoxais.

No século XX, o modelo científico moderno entra em crise, as diversidades e complexidades do mundo contemporâneo desafiam a estabilidade científica de base iluminista. Nesse cenário de crise da matriz do pensamento científico, desenvolve-se a perspectiva pós-moderna. Mesmo com algumas discussões e polêmicas sobre sua denominação, ambígua, complexa e crítica para alguns, acabou sendo uma das expressões mais usadas para representar uma espécie de reação à visão positivista e iluminista (HARVEY, 2000).

A perspectiva pós-moderna é marcada pela heterogeneidade, relativização e questionamento de todos os discursos universais e totalizantes cristalizados na visão moderna. O pensamento pós-moderno acolheu a fragmentação e a efemeridade de maneira afirmativa, a exemplo de Lyotard ao falar do vínculo social-linguístico, não meramente como um tecido único, mas como um emaranhado linguístico, em que o próprio sujeito pode dissolver-se na heterogeneidade de jogos de linguagem (HARVEY, 2000).

Nos territórios do saber científico foram aparecendo novas concepções e posturas críticas às características positivistas e iluministas. Sujeito e objeto, outrora dissociados aparecem numa relação de interligação e interdependência dinâmica, marcadas por princípios de incerteza e indeterminação dos processos de construção do conhecimento. Neste cenário, segundo Morin (1997) emerge a Epistemologia da 
Complexidade, que apregoa que a ciência clássica ortodoxa era simplista e reducionista ao delimitar o real ao formato de seus paradigmas - disjuntivos e mecanicistas. Já a esfera da Epistemologia da Complexidade, em contrapartida, procura compreender as relações de interdependência através de uma visão sistêmica da dinâmica social, caracterizada pela presença do indeterminismo, instabilidade, e não linearidade.

No entanto, mesmo imersos nesse contexto de ambiguidades, fragmentações e complexidades, ainda trazemos como principais referenciais científicos os pilares do paradigma moderno. Nas ciências duras, por exemplo, a máxima de "conhecer é sinônimo de quantificar" ainda está presente, bem como o rigor da delimitação de objetos e métodos. Nas ciências sociais, porém, talvez por conta de suas origens mais próximas ao "despertar pós-moderno", há uma ênfase ao olhar subjetivo. A subjetividade nessa esfera é o que determina a compreensão dos fenômenos sociais a partir de métodos qualitativos, que visam à obtenção de um conhecimento intersubjetivo e compreensivo de um fenômeno social (SANTOS,1987).

A ciência moderna, portanto, se fundamenta no conhecimento voltado à especialização, disciplinarização, e um rigor científico quantificador e objetivo. Todavia ao escolher tais pilares fica refém de fronteiras rígidas que impedem avanços, e também da arbitrariedade e da complexidade do mundo real, que muitas vezes exigem um olhar subjetivo e plural, que se flexibilize a um determinado contexto. Em contrapartida, a ciência pós-moderna é mais contemplativa que ativa, aproximando-se para alguns da estética, por reconhecer a satisfação pessoal e a partilha, podendo assim traduzir-se num saber prático (HARVEY,2000).

Outra distinção marcante na perspectiva pós-moderna é a mudança do papel do conhecimento. Num contexto de transgressão metodológica, em que o valor do objeto por si se minimiza diante das potenciais relações que pode estabelecer com outros objetos, ocorre uma ruptura das barreiras disciplinares, permitindo que o conhecimento possa ser encarado por diferentes pontos de vista dentro de determinado contexto. Dessa forma o conhecimento se desenvolveria não mais pela divisão do saber, mas por uma perspectiva temática, num fluxo dinâmico de temas que permitiriam enxergar suas diferentes interfaces (SANTOS, 1987). 


\subsection{A pós-modernidade e a Ciência da Informação}

Na conjuntura contemporânea, tanto a ciência como o conhecimento mudam de papeis refletindo assim a complexa perspectiva pós-moderna. Segundo Wersig (1991), tal mudança, ao contrário do que o senso comum diz, não se restringe às transformações de uso da tecnologia em informação, a exemplo do que ocorreu na Revolução de Gutenberg. A informação nesta perspectiva funcionaria em função do conhecimento, que para o autor seria tecida através da linguagem. Nessa visão a linguagem caracterizaria os campos do conhecimento, e eles ganhariam na pós-modernidade dimensões e perspectivas distintas àquelas que nos acostumamos a ter no paradigma moderno.

Uma das questões teoricamente mais contundentes para o estabelecimento de um campo científico, segundo a ótica do paradigma moderno, seria a delimitação de um objeto, ideia que se desconstrói no contexto pós-moderno. Neste último, os objetos e fenômenos em si não são as "lentes" escolhidas pelos estudiosos para compreender a ciência contemporânea, mas sim as temáticas e suas inter-relações (TEIXEIRA COELHO, 2005). Com a crise da matriz disciplinar, as estruturas positivistas e iluministas se desconstroem. O conhecimento antes "disciplinado" na especialização do saber e tendo como prioridade a funcionalidade, na esfera pós-moderna ganha um caráter polivalente, desenvolvendo-se em grande parte por analogias, e marcando-se pela pluralidade de métodos, parcialidade e fragmentação.

A fragmentação, por exemplo, não deve ser tomada como um caráter negativo, pois ao contrário da divisão disciplinar - muitas vezes limitadora de perspectivas e ações relacionais -, acaba sendo um sinônimo de possibilidades ao permitir a distensão e o diálogo de estruturas antes intocáveis, a exemplo da relação sujeito/objeto e tempo/espaço (TÁLAMO; SMIT, 2007). O modelo disciplinar, baseado num domínio específico do conhecimento para a construção de um objeto de pesquisa também é questionado e são consideradas outras matrizes para organização de um campo, tais como a interdisciplinaridade, pluri ou multidisciplinaridade e transdisciplinaridade.

Segundo Pombo (1994) a pluri ou multidisciplinaridade seria a justaposição de disciplinas diversas a fim de estudarem um tópico de pesquisa. A interdisciplinaridade, por sua vez seria qualquer combinação entre disciplinas com vista à compreensão de um objeto a partir da confluência de seus diferentes pontos de vista e tendo como objetivo a 
elaboração de uma síntese. Já a transdisciplinaridade seria o nível máximo de integração disciplinar, com a unificação de disciplinas tendo por base a explicitação de seus fundamentos, linguagens, estruturas e mecanismos comuns, com intuito de formular uma visão unitária e sistemática de um setor do saber. Assim, o diferencial entre os três níveis seria a gradação da integração disciplinar.

No entanto, mesmo que tais níveis sejam característicos do mundo pós-moderno, teoricamente, precisamos do paradigma moderno para entendê-los. Nessa perspectiva, Japiassu (1976) afirma que a natureza de qualquer área tem como pressuposto a disciplinaridade, já que uma disciplina antes de tudo deveria delimitar suas fronteiras, objetos, métodos, sistemas, conceitos e teorias, antes de estabelecer qualquer nível de relação com outra.

Por outro lado, Popper (1975) afirma que como estudiosos não devemos nos ater às disciplinas propriamente ditas, ou seja, o foco de uma pesquisa não deve partir de um suposto objeto, mas sim de seus problemas. A partir de problemas podemos incorporar as distintas temáticas, estabelecer métodos e assim constituir uma prática investigativa. Nessa perspectiva podemos pensar a Ciência da Informação como um campo, e não como uma disciplina como sugere Japiassu. Saracevic (1995) compartilha dessa visão quando afirma que a Ciência da Informação poderia ser definida a partir dos problemas abordados e pelos métodos que escolheu para resolvê-los no decorrer do tempo.

Há ainda outros autores que veem o caráter interdisciplinar como algo notório não apenas na Ciência da Informação, como nas demais áreas, considerando que no contexto contemporâneo não há como falar de uma prática disciplinar isolada. González de Gomes (2003), por exemplo, entende que a interdisciplinaridade gera conhecimentos a partir de diferentes modalidades de integração de conceitos, métodos ou abordagens em torno de um problema. Dessa forma, a interdisciplinaridade se desenvolveria dentro de um campo científico a fim de superar e até reformular as fronteiras disciplinares, assim diferente da mera aproximação multidisciplinar, a interdisciplinaridade promoveria um diálogo entre áreas, propiciando a comunicação de conhecimentos, modelos e teorias.

Todavia, mesmo com tal potencial, a Ciência da Informação não tem uma consolidação de suas principais temáticas. Há necessidade de elucidação de seus problemas, assim como de identificar suas interfaces com outras áreas, rotuladas sem 
uma devida discussão e reflexão como "auxiliares", "integradas" ou simplesmente “interdisciplinares". O rótulo interdisciplinar, por exemplo, pode ser precipitadamente atribuído ao se considerar o aspecto contextual da Ciência da Informação, o que pode gerar diluição de questionamentos ou mera incorporação de conceitos (SMIT, 2008).

O caráter interdisciplinar da Ciência da Informação, mesmo considerando o contexto pós-moderno, acaba sendo mais um objeto de afirmação, o que lhe confere um status científico e funcional, do que uma discussão ou explicação consolidada (SMIT; TÁLAMO; KOBASHI, 2004). As autoras ainda ressaltam o perigo de que a mera incorporação de conceitos possa ocorrer sem que se tenha havido uma adaptação aos propósitos da área. Dessa forma, ao invés do conhecimento interdisciplinar se manifestar como uma atividade tradutora, fundada em linguagens, para determinar um tema, pode restringir-se a uma ação meramente descritiva e reprodutora de noções emprestadas.

Tálamo e Smit (2007) ainda salientam que pelo fato da Ciência da Informação se enunciar de modo fragmentado, pode recorrer na verdade à interdisciplinaridade como “álibi de cientificidade”, não assumindo realmente seu caráter de pluridisciplinaridade. As autoras observam que mesmo que a Ciência da Informação esteja imersa num contexto pós-moderno, com potencial temático e relacional, pode ocorrer na verdade o empréstimo acrítico de elementos e métodos de outras áreas, que não necessariamente revertem para em prol da constituição do campo.

Outros autores preferem enxergar a Ciência da Informação sob a "lente" da transdisciplinaridade. Para Brandão (2008), por exemplo, devemos buscar uma atitude transdisciplinar na Ciência da Informação, visão que incentivaria o pesquisador a abrirse às hibridações, e com isso permitir uma reorganização epistemológica, não mais limitada ao objeto e método rígidos, mas aberta ao entendimento de temáticas dentro de um campo do conhecimento.

Assim, mesmo com a ascendência da pós-modernidade, ainda refratamos traços modernos em diferentes esferas sociais: nas estruturas institucionais, profissionais, científicas e até linguísticas, ao buscarmos a "solidez" e a "verdade moderna". Nesse período de transição de paradigmas, o homem contemporâneo tem de um lado a "solidez" da modernidade cristalizada em estruturas as quais ele custa a se desapegar, mas que em contrapartida lhe conferem o alento da "busca por uma verdade", versus a 
"fluidez" da pós-modernidade, dinâmica, inter-relacional, que abrange as nuances da subjetividade e complexidade atual, mas de caráter difuso e imprevisível.

Diante desse contexto plural e complexo novas manifestações científicas nascidas no período de transição de paradigmas também refratam suas vicissitudes e tropeços, a exemplo da Ciência da Informação, que nasce no bojo da esfera pósmoderna, mas ainda sofre as exigências de uma disciplina moderna, já que ainda estamos arraigados a tal modelo (SILVA NETO; SERRI, 2007). A Ciência da Informação poderia ser encarada como uma "tímida personagem” pós-moderna, por um lado olhada a partir de uma perspectiva temática e reconhecida segundo um enfoque organizacional interdisciplinar, mas por outro, pode ser visualizada enredada em seu entrelaçado arcabouço de conceitos, teorias e métodos, "à procura de uma identidade" e uma "consolidação" como campo do saber.

Na tentativa de contribuir à compreensão da configuração do campo da Ciência da Informação, procuraremos discutir duas principais noções para a área: os termos "documento" e "informação". Além da obrigatória revisão bibliográfica, far-se-á uma análise terminológica, com intuito de identificar aspectos mais intrínsecos dos termos, a fim de melhor compreender o papel desses conceitos no contexto da Ciência da Informação. 


\section{Capítulo - Os estudos terminológicos e a Ciência da Informação}

\subsection{Introdução}

No contexto histórico social contemporâneo, os patamares organizacionais e estruturais da Ciência se abalam com a introdução dos valores da perspectiva científica pós-moderna. Se por um lado, pode-se supor a possibilidade de que o "novo" olhar sob a Ciência substitua o "velho" integralmente, por outro, considera-se que nesse momento de transição eles possam conviver no tempo, caracterizando posturas diferentes frente aos fenômenos estudados. Esse contexto, que não pode ser desconsiderado, implica a necessidade de repensar referências, conceitos, bem como de observar a integração do sujeito plural na produção do conhecimento.

O domínio da Ciência da Informação não é imune às variações que resultam dessa crise dos modelos científicos. Isso leva à necessidade de considerar, entre outros, dois problemas, a tentativa de uma "delimitação" de seu objeto de estudo, e as divergências geradas dessa discussão, que desembocam num esforço de definição da área. Mesmo que a ideia de demarcação de um objeto de estudo seja polêmica e cada vez mais questionável no âmbito da mudança de paradigmas, a delimitação do campo é uma necessidade, fato que se caracteriza a partir da circunscrição de sua terminologia.

A Terminologia, como instrumento teórico e metodológico, fornece instrumental para observar as nuances da área da Ciência da Informação sem deixar de observar as variações de uso e sua inserção histórico-cultural. Por meio da identificação de conceitos, termos e definições inscritas nos discursos, é possível verificar as formas de constituição dos domínios, seu desenvolvimento, bem como as relações que estabelecem com domínios fronteiriços.

Como já destacamos anteriormente na Introdução, para Lara (1993), mais do que contribuir para a identificação dos termos, a importância dos referenciais da Terminologia (teórica e concreta) é fornecer a base para identificar como os termos estão sendo utilizados socialmente. No caso da Ciência da Informação que tem uma identidade "nebulosa", o instrumental terminológico pode contribuir para enxergarmos melhor os traços da área.

Considerando a relevância do estudo terminológico, nesse capítulo faremos uma revisão de literatura sobre a Terminologia abordando, um breve panorama, sua constituição histórica, principais vertentes, bem como seus conceitos incluindo a discussão que o campo também realiza sobre seu aspecto interdisciplinar. Depois disso, 
procuraremos verificar o papel da Terminologia na Ciência da Informação e, por fim, apresentaremos alguns fundamentos teóricos terminológicos utilizados na análise terminográfica realizada.

\subsection{Terminologia: breve histórico e principais vertentes}

A história da Terminologia, assim como sua concepção e utilização, está muito ligada a duas noções: a prática e a delimitação de uma área. A primeira noção é remota, pois desde as civilizações mais antigas, notamos uma necessidade de nomeação de seres e coisas para contextos específicos. Tal ação propiciou tanto o desenvolvimento da comunicação oral humana, contribuindo com as organizações sociais, como serviu de base para o surgimento da expressão escrita, que permitiu o registro e a compilação de termos criados culturalmente. Já a segunda noção, segundo Cabré (1993), surge entre os séculos XVIII e XIX quando os cientistas, preocupados com a proliferação e uso descoordenado de designações, resolvem fixar as denominações científicas, com intuito de organizar e formalizar as disciplinas.

Mesmo com a prática remota, a sistematização e a fixação de um estatuto científico da Terminologia é recente. Lineu (1707-1778) foi um dos precursores do estudo terminológico voltado às taxionomias. No século XIX e logo após, com o acelerado desenvolvimento técnico e científico do século XX, a Terminologia se consolidou cientificamente. A "Terminologia moderna" iniciou-se com os trabalhos de Lotte (1888-1950), da escola soviética, e de Wüster (1897-1977) da escola austríaca. O primeiro se detinha aos aspectos teóricos e metodológicos da Terminologia, encarandoa como disciplina científica influenciada pela Filosofia. $\mathrm{O}$ segundo, influenciado pela Lógica, se preocupava com o tratamento dos dados terminológicos e sua padronização, tomando a Terminologia como uma disciplina autônoma de caráter interdisciplinar, com função de atuar a serviço das demais disciplinas técnico-científicas (CABRÉ, 1993).

Além dessas duas escolas clássicas, Cabré (1993) também comenta sobre a escola tcheca, mais centrada na Linguística, que considera a Terminologia como um subcomponente do léxico da língua e das linguagens de especialidade. Todavia, das três principais vertentes a que foi responsável pela formulação das normas internacionais de padronização terminológica e serviu de base teórico-metodológica para as linhas de estudo contemporâneas no Ocidente, foi a escola austríaca. 
$\mathrm{Na}$ época de seu surgimento havia uma demanda pela normalização, e a perspectiva lógica, trazida pela escola austríaca, permitia um trabalho mais objetivo se comparado à linha soviética, de viés filosófico. Além disso, o idioma nos trabalhos de Lotte também foi um fator que prejudicou a expansão de sua pesquisa no Ocidente, sendo que até hoje é pouco conhecida.

$\mathrm{Na}$ atualidade, mesmo reconhecendo a importância da herança da escola de Viena para a delimitação dos pilares terminológicos, critica-se a ênfase normativa da Terminologia clássica. Na perspectiva contemporânea o termo não deve ficar restrito ao âmbito normativo, mas ser analisado em seus diferentes contextos discursivos, o que permite encontrar seu valor como uma unidade significativa de uma área na perspectiva do uso.

Seguindo esses pressupostos, podem-se destacar os seguintes estudos contemporâneos da Terminologia: a Teoria Comunicativa da Terminologia, fruto dos trabalhos de Cabré e seus colaboradores do IULA (Instituto de Linguística Aplicada de Barcelona) na Espanha; a Socioterminologia, com os trabalhos de Gaudin (França) e Auger (Canadá); a Terminologia Cultural, com Diki-Kidiri (Senegal); a Terminologia Cognitiva, com Temmerman (Alemanha), e ainda diversos trabalhos que se utilizam da Teoria do Discurso e da Linguística Textual, mais voltadas aos aspectos linguísticos, semióticos e pragmáticos (LARA, 2005). No âmbito deste trabalho será utilizada a vertente da Teoria Comunicativa da Terminologia, representada por Cabré e os pesquisadores do IULA.

\subsection{O conceito de Terminologia}

O conceito de Terminologia é polissêmico, logo, é necessário identificar sob qual aspecto estamos tratando o termo. Segundo Cabré (1999), há basicamente três noções para o termo: pode ser uma disciplina, ou seja, uma matéria que se ocupa de termos especializados; uma prática, conjunto de princípios encaminhados à recopilação de termos; ou um produto, conjunto de termos de determinada especialidade, gerado pela prática. A Linguística Documentária, por exemplo, recorre à teoria (disciplina) para compreender a formação dos conceitos e sistemas de conceitos nos domínios; à prática (metodologia), para compreender e operacionalizar as relações entre conceitos; o produto (as terminologias, expressas em dicionários terminológicos, glossários), para fundamentar as escolhas na organização das linguagens documentárias. 
Outro aspecto importante para entendermos a abrangência terminológica é compreender as distinções entre Terminologia e Lexicologia (CABRÉ, 1993). Elas diferem principalmente quanto à sua função: a Lexicologia recopila denominações numa obra de referência com finalidade informativa ou descritiva, já a Terminologia, não se limita às recopilações, mas pretende delimitar para um contexto as unidades terminológicas como formas normalizadas voltadas à comunicação científica (CABRÉ, 1995). Pode-se dizer ainda que se diferenciam também quanto ao objeto de estudo, ao tratamento e apresentação dos dados recopilados e na orientação do trabalho.

Uma diferença, até então, crucial entre elas, era quanto ao objeto de estudo. Enquanto a Terminologia estaria centrada no termo, de caráter unívoco e produto de uma determinada especialidade, a Lexicologia se fundamentaria na palavra, de caráter polissêmico, enquanto unidade que assimilaria aspectos diacrônicos e sincrônicos. No entanto, atualmente, com as vertentes terminológicas cada vez mais voltadas à questão do contexto de uso dos termos, tal distinção entre termo e palavra fica relativizada.

Outra distinção apontada por Sager (1990) é a atitude em relação à coleta e organização do material a ser processado. Geralmente os lexicógrafos partem das palavras em uso para construírem listas, que posteriormente são usadas na delimitação das acepções. Já os terminólogos tratam primeiro das relações conceituais e entendimento dos campos semânticos, para depois chegarem à denominação desses conceitos. Assim, na maioria das obras lexicográficas, a exemplo dos dicionários de língua, temos a perspectiva semasiológica (termo para o conceito). Enquanto grande parte do trabalho terminológico inicia-se a partir da visão onomasiológica (conceito para o termo).

Quanto à prática, tanto a Terminologia como a Lexicologia possuem vertentes aplicadas específicas: a Terminologia com a Terminografia, e a Lexicologia com a Lexicografia. Em comum, ambas têm o objetivo de orientar na elaboração de materiais especializados, no caso dicionários temáticos, vocabulários e glossários na Terminografia e dicionários de língua na Lexicografia. No entanto, a orientação dos trabalhos é distinta. Na Terminografia, há uma preocupação, desde a seleção do corpus à coleta e análise dos termos, em objetivar os resultados dentro de um domínio específico. Além disso, mesmo que durante o tratamento dos dados haja uma diversidade de definições, sinônimos e inter-relações semânticas, ao se produzir o material especializado chega-se a uma noção consensual dos termos, a fim de facilitar a recuperação (BIDERMAN,1984). 
Na Lexicografia a metodologia de trabalho é mais abrangente, incluindo não só aspectos semânticos da palavra, como os morfossintáticos, etimológicos, diatópicos e diacrônicos. Ao contrário da Terminografia que procura voltar-se a um campo semântico específico, observa-se na Lexicografia a tentativa de apresentar as diferentes faces de uma mesma palavra, imaginando para isso uma diversidade maior de público, que tem níveis de linguagem e necessidades de busca muito distintas.

Ratificando tal ideia temos Le Guern (1989) acentuando a distinção entre termo e palavra. $\mathrm{O}$ autor afirma que o primeiro é a unidade efetivamente utilizada no discurso de especialidade, enquanto a palavra é um mero estoque de acepções, que independe da coisa em si, produto de convenções arbitrárias. A palavra possui um significado, mas não referência, pois apenas exprime um conjunto de propriedades, destacando assim o caráter da intensão. Já o termo, inserido no discurso, tem as propriedades definidas a partir do contexto em que aparecem, caracterizando a extensão, já que as palavras adquirem significados particulares.

Assim, um termo é delimitado através da definição, que ocorre dentro de um campo nocional ou conceitual. Diferente da perspectiva lexicográfica, a terminológica observa a palavra no interior do subconjunto linguístico específico e com características particulares que correspondem ao discurso da especialidade e a um determinado contexto de uso. Portanto, para se definir um conceito não basta simplesmente estabelecer um significado, mas delimitar inter-relações de um dado domínio do saber e considerar sua situação de uso no âmbito de uma comunidade científica.

\subsection{O caráter interdisciplinar da Terminologia}

Considerando a Terminologia como uma disciplina teórica e aplicada, observase que ela envolve a descrição e o ordenamento do conhecimento, tanto num nível cognitivo como comunicacional, utilizando como elementos-chave conceitos e termos. Compreende o estudo científico dos conceitos e seus respectivos termos considerando seu funcionamento social e sua inter-relação com outras áreas, já que também se constitui como um campo inter e transdisciplinar (CABRÉ, 1999).

No contexto interdisciplinar estabelece relações com outras disciplinas (Ciências da Linguagem, Ciências da Comunicação e Ciência Cognitiva). Já no âmbito transdisciplinar muda-se o enfoque, ou seja, é a Terminologia que participa da 
constituição de diversas matérias de especialidade, considerando que não se faz ciência sem o aporte terminológico.

Assim, o caráter transdisciplinar é facilmente identificado ao se constatar o valor da Terminologia para a construção de um campo científico. Nesse viés, a Terminologia destaca-se pelo papel de caracterizar uma linguagem especializada a fim de representar a estrutura conceitual de um domínio (CABRÉ, 1999). Exemplos de tal aplicação são as disciplinas técnico-científicas, que enxergam a terminologia como um conjunto de unidades de comunicação que permitem a transferência do pensamento especializado. Nesse uso, os termos têm um caráter monorreferencial, o que possibilita precisão e univocidade na comunicação científica especializada.

A produção do conhecimento científico se constitui a partir de um tripé epistemológico: a delimitação de um campo de conhecimento, uma metodologia adequada à pesquisa, e uma terminologia própria. No contexto movediço da contemporaneidade, em que convivem referências modernas e pós-modernas, os estudos terminológicos facilitam a delimitação de campos de conhecimento e a identificação de conjuntos de termos próprios de um domínio. Assim, sem a Terminologia, os especialistas não conseguiriam se comunicar, repassar seus conhecimentos, nem representar esse conhecimento de forma organizada (DIAS, 2000).

Por outro lado, enxergando a Terminologia sob o aspecto interdisciplinar, verifica-se que ela dialoga com outras disciplinas. Cabré (1999) ressalta três delas: a Tradução, a Informática e a Documentação. Nos três casos, a Terminologia auxilia os domínios na descrição ou representação de forma normalizada e unívoca de seus conteúdos. Na Tradução atua no papel de representar um conhecimento e transmiti-lo. Já na Informática auxilia a recuperação de dados nas linguagens de especialidade, facilitando o armazenamento e organização dos dados. E na Documentação ${ }^{3}$, é o elemento-chave para os processos de Indexação e a Recuperação de documentos, traduzindo as unidades de caráter comunicativo (linguagem natural) em unidades de caráter operacional (linguagem documentária), a exemplos dos dicionários técnicos especializados, glossários e tesauros.

\footnotetext{
${ }^{3}$ No texto em referência, a autora usa o termo "Documentação" (em maiúscula) para se referir à disciplina. Em outro momento dessa obra fala da "documentação" (em minúscula), para se referir aos diferentes tipos de materiais, os documentos usados no trabalho terminológico para a coleta de termos (CABRÉ, 1993).
} 
A interface da Terminologia com outros domínios revela que no contexto pósmoderno, caracterizado por diversidade e a multiplicidade de pontos de vista na produção, uso e consumo informacional, torna-se necessário considerar uma outra perspectiva terminológica, diferente da clássica. Cabré, numa abordagem que acolhe tais valores, aponta as principais características da Terminologia no âmbito do contexto contemporâneo:

La terminología es una materia de base semántica, y los términos son unidades que relacionan el lenguaje y la realidad, que representan objetos de la realidad; con los términos, los individuos expresan e intercambian pensamientos y organizan la estructura de base de una disciplina. La polivalencia de los términos se justifica por su multidimensionalidad. (CABRÉ, p.93, 1993)

Pelo exposto, nota-se que a Terminologia se converte tematicamente como base para a estrutura do conhecimento especializado. No lugar de estruturas fixas e unidirecionais que refletiriam uma organização disciplinar, destaca-se o uso, a partir do qual são incorporados o dinamismo e as inter-relações disciplinares. Considerando tal dimensão, pode-se destacar como exemplo a utilização da Terminologia pela Ciência da Informação. A Terminologia pode contribuir tanto na emblemática questão da denominação da Ciência da Informação, ainda muito "nebulosa", como auxiliar na identificação das diferentes nuances que configuram a área.

\subsection{Terminologia: subsídios para delimitação do domínio da Ciência da Informação}

Atualmente, num cenário de ambiguidade e fragmentações, o modelo de racionalidade científica se transforma e com isso assume novas perspectivas. As Ciências Duras, por exemplo, outrora consolidadas pelo rigor científico, especialização, e objetividade, se veem desestabilizadas por terem que ponderar a relatividade, a subjetividade e a pluralidade de condições da conjuntura científica contemporâneo (SANTOS, 1987).

No âmbito das Ciências Sociais Aplicadas tal confluência de paradigmas também é notória, visto que ela possui diversos campos "filhos" da pós-modernidade, mas que ainda carregam a "herança disciplinar" e metodológica da modernidade. A Ciência da Informação, por exemplo, por realizar diálogos e trocas interdisciplinares vive um impasse: por um lado amplia seu campo de atuação, trabalhando não com 
assuntos determinados, mas com problemas; mas por outro lado, por ter nascido num momento de transição de modelos científicos traz em seu bojo traços da modernidade.

Nesse ponto entra em cena a linguagem. Diferente da ideia simplista de associar a linguagem a um mero instrumento de codificação passa-se a associá-la à cultura, que desempenha um relevante papel na representação dos processos sociais e na geração de sentido. Considerando a linguagem como uma ampla faculdade humana que integra produção, recepção, pensamento e expressão, tanto numa dimensão individual quanto social (PAVEAU; SARFATI, 2006), fica mais fácil identificar sua ação concreta no domínio da Ciência da Informação.

A importância da Linguagem na Ciência da Informação é objeto da Linguística Documentária, que se preocupa com o estabelecimento dos princípios teóricos e metodológicos da linguagem documentária, encarregando-se de estudar as estruturas simbólicas da Documentação, bem como as formas mediadoras informacionais entre emissores e receptores (TÁLAMO; LARA; 2006). A Linguística Documentária integra princípios da Terminologia, procurando apoio para a identificação de termos e conceitos correspondentes, bem como sua organização em domínios e áreas de atividade. A Terminologia (teórica) e a terminologia (concreta) apoiam a construção de linguagens documentárias.

A Linguística Documentária reconhece que para resolver os problemas da informação é preciso buscar respostas nas Ciências da Linguagem. Assim, para desenvolver-se, busca subsídios na Linguística Estrutural, Semiótica e campos afins, como na Análise do Discurso e nas Ciências Cognitivas (TÁLAMO, 2001). Da Linguística Estrutural, por exemplo, a Linguística Documentária se apropria do arcabouço teórico do sistema de estrutura linguística, com destaque para os aspectos de arbitrariedade, a estruturação relacional, e a ideia de convenção/representação da língua. Já a Semiótica contribui com a noção do sistema signíco, base para os processos comunicacionais e de significação, e que corrobora a constituição de um signo documentário $^{4}$ (TÁLAMO; LARA, 2006).

\footnotetext{
${ }^{4}$ Segundo Tálamo e Lara (2006) o signo documentário é um código razoavelmente impreciso, até circunstancial, que funciona como uma unidade de uma linguagem intermediária, dependendo assim de outros sistemas semióticos para ser "traduzido". É parte de um sistema sígnico em que a unidade mínima é o descritor, elemento que pode ser confundido com a palavra, entretanto são mais facilmente expressos por sintagmas nominais, não formulando assim argumentos.
} 
Mesmo com importantes contribuições, nem a Linguística nem a Semiótica, bases da Linguística Documentária, resolvem a questão da delimitação temática e funcional da Ciência da Informação, pois não oferecem um instrumental "concreto". Não obstante, a Terminologia preenche tal lacuna, já que aborda tanto aspectos teóricometodológicos, contribuindo na formulação de redes lógico-semânticas, como práticos, fornecendo referencial para seleção de descritores ou mesmo oferecendo suporte para os procedimentos da linguagem documentária (TÁLAMO, 2001).

O uso da "terminologia concreta" permitiu a possibilidade de conferir um valor mais pragmático aos descritores, que até então eram fortemente influenciados pela Terminologia clássica, voltada à normatização. Mesmo considerando a pertinência dessa vertente tradicional, principalmente por ter contribuído para a elaboração das normas terminológicas internacionais (ISO 704-2000 e ISO 1087/1-2000) e outros textos de base teórica, havia necessidade, ao se considerar a perspectiva interdisciplinar e a pluralidade dos pontos de vista de produção, uso e consumo informacional na atualidade, de uma terminologia voltada às questões heterogêneas do uso dos termos em um contexto (LARA, 2006).

Dessa forma, notamos que o uso de referenciais terminológicos na Ciência da Informação não é apenas de caráter normalizador, mas considera o contexto do uso. Assim, como observa Lara (2006): "O diálogo entre as áreas supõe, hoje, que o conhecimento não é dado, mas produto da interpretação, o que solicita que as bases da interlocução não releguem a multiplicidade das possibilidades de organização conceitual urdidas nos espaços de atuação ou nas comunidades científicas".

Smit, Tálamo e Kobashi (2001) ressaltam que considerando o cenário pósmoderno, a discussão acerca das conceituações e das interfaces da Ciência da Informação com outras áreas do conhecimento torna-se relevante. $O$ trabalho terminológico teria, nessa conjuntura, o importante papel de auxiliar na "reintrodução" do significado "oculto" da natureza identitária da Ciência da Informação. A partir do reconhecimento de seus conceitos próprios e daqueles que constituiriam empréstimo, sendo possível identificar sua autonomia, conseguindo com isso definir melhor seus objetivos, bem como reconstituir as características dos conceitos básicos da área. Segundo as autoras, tal caminho facilitaria a "descoberta" da área e não a mera demonstração do que ela seria.

Todavia tal descoberta pode enfrentar alguns percalços. As autoras lembram que a ausência de um assentamento conceitual, ou mesmo a presença de ambivalências 
semânticas criam um retardamento teórico, que impede avanços na área. A terminologia nesse sentido, se usada na perspectiva clássica, a partir da delimitação de denominações, estabeleceria um vocabulário monorreferencial de uma especialidade. Porém, considerando as nuances da perspectiva contemporânea que incorpora a questão do uso, tal delimitação conceitual também pode acontecer, desde que se considere o contexto como elemento-chave para resolver tais impasses. Dessa forma, verificamos que a Terminologia, tanto em sua faceta clássica como nas nuances contemporâneas fornece subsídios para a identificação de conceitos e traços que contribuam para o delineamento do campo da Ciência da Informação.

\subsection{Terminologia: aporte teórico}

Considerando que a Terminologia tem como objetivo organizar um conjunto de noções de determinado domínio específico do conhecimento, é relevante antes de verificar seus procedimentos sistemáticos de seleção, análise e síntese, compreender a natureza de seus conceitos elementares. Para isso serão definidos os seguintes elementos terminológicos: termo, definição, noção, conceito, e característica.

O termo é a unidade terminológica básica que têm a função de representar e transferir o conhecimento especializado. Os termos constituem um subconjunto de signos linguísticos relativos a uma área conceitual e utilizados na comunicação especializada. Para se delimitar um termo é necessário realizar uma definição. Rey aproxima as palavras "termo" e "definição" a partir de um traço comum: ambas designarem a origem da atribuição de um limite, (de um fim, "de-finir") e de seus resultados (termo). No plano nocional, para que um nome tenha o "direito" de ser denominado "termo" ele precisa ser elemento de um conjunto e distinguir-se de outros elementos. O meio para exprimir esse sistema de distinções é através da definição. Diferente da mera descrição, que acumula todos os traços característicos, pertinentes ou não, a definição por sua vez explicita apenas os traços pertinentes à compreensão da significação (REY, 1979).

Já Sager (1990) generaliza a noção de definição dizendo que ela é a descrição linguística de um conceito, baseada num conjunto de características que convergem para o significado de um conceito. Esse processo de referir "alguma coisa" a um termo e de um termo a um conceito, pode ser feita a partir de vários métodos, geralmente delimitados a partir da natureza do conceito que será definido. Esta "natureza do 
conceito" a ser definido, somada às necessidades do usuário, são os aspectos ressaltados pelo autor como determinantes para delimitar uma definição.

Quanto às origens, a palavra "definição" provém da tradição aristotélica e da escolástica que distinguiam as definições de palavras e as definiçõos de coisas. Todavia, efetivamente, do ponto de vista linguístico, a palavra tinha a função de "sugerir à mente", num determinado ambiente histórico, algo a respeito de um dado objeto (IMBS, 1960 apud WELKER, 2004). Nas definições aristotélicas fala-se de um "gênero próximo", relativo a uma compreensão mais abstrata e geral a ser definida e de uma "diferença específica", para tratar das várias maneiras de se definir algo a partir de suas características. Esse tipo de definição, também denominada como analítica desdobra os semas ${ }^{5}$, organizando-os numa relação de gênero-espécie.

Segundo Welker (2004), quando se fala em trabalhos sobre definição podem-se diferenciar três tipos de definições principais: as enciclopédicas, as lexicográficas e as terminológicas. A primeira funciona como um conjunto de informações enciclopédicas, ou seja, há uma longa descrição do objeto definido com intuito de funcionar como um resumo de um determinado conhecimento. Na definição lexicográfica objetiva-se construir proposições que enunciem a equivalência entre um definiendum (aquilo que deve ser definido) e o definiens (aquilo que define). Segundo Rey-Debove (1966, apud WELKER, 2004) inicia-se a definição pelo definiendum, considerando o signo que se refere a um conceito; tal conceito deve ser dividido em conceitos menos complexos, expressos por vários signos, os definiens, o que acaba compondo acepções de natureza analítica ou de base aristotélica.

A definição terminológica semelhante à lexicográfica também se constitui de uma enunciação de equivalência entre um termo, o definido, e um conjunto de características que o definem. É uma operação que procura determinar o conjunto de características importantes para a compreensão de um conceito. Para isso, assim como na definição lexicográfica, verifica-se que o modelo analítico, de caráter hiperonímico e lógico seria o mais recomendável na maioria dessas definições. Porém, há circunstâncias, especialmente em alguns domínios, em que tal tipo de definição não é conveniente. Nesses casos podem ser usadas as definições por função, que descrevem

\footnotetext{
${ }^{5} \mathrm{Na}$ análise sêmica, o sema corresponde à unidade mínima de significado. Ele não tem uma realização independente, já que se realiza apenas dentro de uma configuração semântica, ou semema. Assim, o semema é o conjunto de traços significativos ou de semas mínimos (ULLMANN, 1977).
} 
uma ação e suas etapas ou até a pseudodefinição, feita com sinônimos e antônimos (SILVA, apud WELKER, 2004).

Sobre a definição terminológica, Rey (1979) diz que ela estaria entre a definição lexicográfica e a enciclopédica, destinada a melhorar o uso das palavras para permitir seu funcionamento como termo, evocando (e não reproduzindo ou representando) o modo de construção das classes e o funcionamento dos esquemas conceituais. $\mathrm{O}$ autor ainda pondera que uma definição terminológica pura é impraticável, já que ela é formada pela língua natural, veículo que incorpora todo tipo de ambiguidade, polissemia e conotações. Além disso, a própria ideia de um "domínio puro" para delimitar uma definição também é questionada pelo autor, já na década de 70 . Hoje, com a difusão do caráter interdisciplinar nos diferentes domínios, marcados por heterogeneidade e complexidade nas relações entre as áreas, fica inviável falar de tal pureza de domínio.

Sager (1990) também aborda a noção de definição terminológica. Para ele a definição terminológica é uma especificação semântica do termo que está documentado, e através dele é fonte de referência. Dessa forma, no âmbito terminológico as definições não deveriam ocorrer de forma isolada, mas serem consideradas a partir de um contexto, já que os terminólogos precisam dele para realizar a compilação de termos e a proposição de novos termos. A observação das condições de uso é fator relevante para a "captura" de novos termos, os neologismos. Geralmente inseridos de forma provisória em um domínio, a partir de uma relação conceitual provisória, somente são validados pelo contexto, passando a se incorporar a um léxico de uma linguagem de especialidade, e a "ganhar" a dimensão terminológica de "termo-definição-conceito".

Além disso, Sager (1990) ainda demarca algumas "necessidades básicas" para que uma definição possa ser considerada como terminológica: a fixação inicial da equação termo-conceito; a identificação do termo via verificação da existência e independência da definição; e a exploração do significado do conceito por um especialista ou usuário do sistema. E também expõe outros tipos de definições, não tão comuns na atividade terminológica, mas que podem aparecer na modalidade mista. São elas: a definição por implicação (utilização de uma palavra explicitando o contexto); definição por denotação (lista de exemplos, por extensão de significado); definição por demonstração (definição ostensiva); definição por síntese (identificação de relações e sua descrição de forma sintética); e a comum mistura de tipologias, a exemplo das definições que englobam características analíticas e sinonímicas. 
O conceito, por sua vez, é uma unidade de pensamento constituída por uma abstração mental, proveniente da atribuição de propriedades ou características comuns de um objeto ou classe, conforme a ISO 704 (2000). Quando um conceito refere-se a um objeto singular, temos um conceito individual, que é um exemplo do conceito geral e que é geralmente expresso por um nome próprio (LARA, 2005).

As características podem ser definidas como uma representação de uma propriedade, que têm o papel de delimitar um conceito. Logo, a noção de conceito está imbricada à noção de característica, já que o conceito é um conjunto de características interrelacionadas que descrevem uma classe de objetos da realidade, ou como prefere a Norma ISO 1087 (2000, p.2) uma "unidade de conhecimento criada por uma combinação única de características". A identificação dessas características se dá a partir da análise conceitual no interior de um domínio, tanto na perspectiva da intensão, reunião de características comuns a uma unidade para formar um conceito, como da extensão, quando os objetos são reunidos sob um conceito em causa.

Tanto as características como os conceitos, segundo a Norma ISO 704 (2000) podem se subdividir. As características podem ser divididas em essenciais ou não essenciais, considerando se são ou não indispensáveis para o entendimento de um conceito; ou delimitadoras, quando distinguem um conceito de outro num sistema conceitual. Já os tipos de conceito, além das noções de individual e geral, se caracterizam a partir das relações que estabelecem entre si, que são principalmente as relações hierárquicas (conceito genérico e conceito específico) e associativas (LARA, 2005).

Tais relações entre conceitos são basicamente de duas ordens. Na relação hierárquica os conceitos são organizados em níveis (superordenado, subordinado e coordenado) e compreendem dois tipos de relações: a partitiva e a genérica. Todavia, na relação associativa, os conceitos são relacionados por uma conexão temática, ou seja, têm como base proximidades espaços-temporais, como por exemplo, as relações de causa e efeito, conteúdo e continente ou etapas de um ciclo (LARA, 2005). Do que foi dito, podemos concluir que os conceitos não existem isoladamente, pois é imprescindível considerar a relação que estabelecem entre si.

Outro autor que traz uma importante perspectiva para a compreensão do conceito é Rey (1979). Para ele a palavra “conceito" é geralmente empregada em francês na Filosofia, Lógica, Linguística e Epistemologia para designar o "ato de pensar e o objeto do pensamento (ideia)". Já a palavra "noção" é considerada pela tradição 
filosófica como "objeto de conhecimento, que coloca um objeto e o definido em perspectiva de sua ação”. Dessa forma, mesmo reconhecendo o valor indispensável dos termos derivados de "conceito"- "conceitualizar", "conceituação" e "conceitualização"-, o autor ressalta que, em francês, com o intuito de conservar o sentido de "concept" em inglês, emprega-se o termo "noção" ao invés de conceito, no âmbito da terminologia descritiva e aplicada.

Etimologicamente a palavra "noção", do latim notio, refere-se a um caráter próprio e tem natureza originalmente semiótica. Já a palavra "conceito" está vinculada à "mente", derivada da ideia de "conceber". Dessa forma, a noção acaba sendo empregada antes de tudo para conceituações mais individuais ou acepções adotadas por uma parte de um grupo social (Rey, 1979). Ela constitui uma definição “menos rigorosa" e mais genérica que aquela relacionada ao termo conceito. Essa perspectiva mais "aberta" do termo noção foi o elemento motivador da escolha desse termo ao invés de conceito para o escopo deste trabalho.

Para concluir esta etapa teórica falta falar do papel do contexto na prática terminológica. Rey, antes de qualquer outro autor, já mencionava em sua obra Le terminologie-noms et notions, de 1979, a importância de se considerar o contexto na atividade terminológica. Lembrava que as condições sociais, linguísticas, culturais, além da heterogeneidade das especializações e práticas do saber influenciavam o escopo da atividade terminológica.

Atualmente, com a flexibilização das disciplinas e o aumento do diálogo interdisciplinar, o viés normalizador da Terminologia Clássica se desestabiliza. As práticas terminológicas antes muito balizadas por uma visão estática das disciplinas, hoje com o movimento dinâmico e heterogêneo do conhecimento são revistas à luz do contexto. Para Gaudin (1993) a questão do contexto no âmbito terminológico está ligada às práticas sociais, bem como ao reconhecimento dos sujeitos que estão envolvidos nessas práticas para a produção de conhecimento. Ressalta que a prática terminológica deve ser inseparável do conhecimento, que se dá no "terreno da ação", referindo-se ao contexto sociolinguístico. Tal contexto, no âmbito da Socioterminologia ${ }^{6}$, considera que

\footnotetext{
${ }^{6}$ A Socioterminologia é a vertente de estudo defendida por Gaudin. Com origens na Sociolinguística e fundamentada por esforços pluridisciplinares, a atividade terminológica ocorre sob o viés das práticas sociais, contando ainda com influência de aspectos culturais e políticos para constituir-se (GAUDIN, p.81,1993).
} 
o objeto científico se constitui a partir do discurso, baseado em parâmetros linguísticos, sociais e extralinguísticos que determinam o uso.

No próximo capítulo, antes da análise terminológica propriamente dita, feita a partir da abordagem contemporânea da Terminologia, será realizada uma revisão de literatura sobre os termos "documento" e "informação". Serão apresentadas algumas de suas definições clássicas feitas por autores francófonos, anglo-saxões, escandinavos, espanhóis e brasileiros. 


\section{Capítulo - Revisão de literatura dos termos 'documento’ e ‘informação'}

\subsection{Introdução}

Depois de compreendermos um pouco do contexto de criação e desenvolvimento da Ciência da Informação e de tratarmos sobre a perspectiva terminológica que é utilizada como aporte metodológico deste trabalho, é o momento de resgatar as noções de "documento" e "informação" no âmbito da Ciência da Informação. Tal revisão de literatura nos mostrará que mesmo com diferentes perspectivas sobre tais noções, os autores parecem concordar com a importância desses termos na compreensão da identidade da Ciência da Informação.

Dessa forma, o objetivo deste capítulo é apresentar uma revisão de literatura sobre os termos "documento" e "informação", a partir da ótica de autores de referência do domínio da Ciência da Informação. Como já foi mencionado anteriormente, o processo de seleção desses autores foi realizado em quatro etapas. A primeira foi a consulta dos termos feita em dicionários da área, com o objetivo de ter uma noção inicial da definição dos termos. A segunda foi a busca de resumos na base LISA (Library Information Science Abstracts) que teve como objetivo fazer um primeiro mapeamento de possíveis textos que serviriam para o corpus de trabalho. Num terceiro momento, a partir da sugestão bibliografia da disciplina de "Informação e Cultura", foi ampliada a pesquisa inicial e selecionados os principais autores para compor a revisão histórico-conceitual, com destaque para LUND (2009), CAPURRO (2007) e ORTEGA (2004; 2008; 2009abc; 2010). E por último, foram acrescidos autores sugeridos pelos três "autores-chave", pesquisados principalmente nas bases de textos completos do Portal Capes.

\subsection{Noções do termo documento}

\subsubsection{Autores francófonos}

Otlet em sua obra clássica, o Traité de Documentation (1934), enuncia de forma revolucionária para o período a ideia de documento. Primeiramente parte de um termo genérico, biblion, cujo significado é associado a uma unidade intelectual e abstrata, que poderia ser representada concretamente em modalidades diversas (revistas, filmes, livros, etc). Dentre tais modalidades destaca-se o livro, suporte de certa matéria e dimensão em que se incluem signos representativos de certos dados intelectuais. 
Todavia, tanto o livro como o biblion, trazem em suas raízes etimológicas referências diretas ao livro, o que para o autor limitaria o conceito a uma tipologia.

Diante disso, Otlet propõe o uso da palavra documento, que de teor mais abrangente poderia representar qualquer coisa em que o conhecimento pudesse ser registrado e que se reconhecesse alguma propriedade informativa. Segundo Rabello (2009) tal acepção otletiana, ao ser concebida numa época de influência positivista, considerou a ação humana de agregar ao objeto uma função informativa, o que garantiu um status de objetividade ao termo. Logo, o que interessaria no documento não seria seu conteúdo cognitivo em si, mas o que fosse projetado sobre o seu suporte documental, além de compreender o que foi depositado nele. Nesse viés, o documento teria uma importante projeção de memória gráfica, auxiliando na preservação da memória da humanidade, o que corroboraria os intuitos pacifistas e universalistas de Otlet.

Além de o documento assumir um papel central no ideário pacifista, o autor ainda esmiúça suas diferentes nuances. Diz, por exemplo, que em todo documento devem ser consideradas três ordens de elementos: os materiais (substância, forma, acabamento), os elementos gráficos (textos, imagens reais ou convencionais), e os elementos intelectuais, que segundo ele seriam os mais importantes, mas estariam vinculados aos dois primeiros (OTLET, 1934). Assim, concluía que o documento era o resultado de múltiplas operações e combinações, sendo aproveitado em sua elaboração os elementos de todos os estágios anteriores, além dos novos, formando assim uma cadeia de elos interdependentes e solidários.

A noção de documento encetada por Otlet foi consolidada por seus discípulos, especialmente os franceses, responsáveis por disseminar o estudo da Documentação na Europa, que teve seu apogeu na primeira metade do século XX. Durante a Segunda Guerra Mundial passou por relativo esquecimento e foi retomada, principalmente na França pela funcionária da Biblioteca Nacional, Suzane Briet.

Briet vivia o momento do pós-guerra: por um lado se via influenciada pelo olhar um tanto utópico de Otlet, carregado de influências iluministas, e por outro lado vivia o despontar da Teoria da Informação e a Cibernética, frutos das inovações tecnológicas e sócio-culturais do período. Diante disso, abordou a ciência e a cultura no contexto 
global do pós-guerra, caracterizando o documento a partir de contextos institucionais e culturais. Em sua obra clássica, Qu'est-ce que la documentation? (1951) retoma a definição da UFOD (Union Française dês organismes de Documentation) de caráter mais genérico: "une preuve à l'appui d'un fait" (BRIET, p.2, 1951). Tal perspectiva ressalta o valor do documento como evidência, ou seja, uma base de conhecimento fixada materialmente capaz de ser usado para "consulta", "estudo" ou "prova".

Partindo dessa definição Briet elabora a sua, destacando a natureza simbólica do documento e definindo-o como:" tout indice concret ou symbolique, conservé ou enregistré, aux fins de représenter, de reconstituer ou de prouver um phénomène ou physique ou intellectuel"(BRIET, p. 2, 1951). Essa noção permitiria que o documento atuasse tanto como signo, quando houvesse conexão física com o objeto representado (documento primário), ou símbolo, quando tal conexão física não existisse (documento secundário) (LUND, 2009).

Para ilustrar sua acepção usa o exemplo do antílope africano, que não nasce com o status de documento, mas a partir de um contexto sociocultural e de um ato interpretativo "ganha" tal valor. Rabello (2009) destaca que Briet inicia uma fase hermenêutica na Documentação, pois entende o documento como um produto de uma ação interpretativa, ou seja, o aspecto valorativo de um documento é dado a posteriori, fruto de uma conjuntura social e cultural que envolve o sujeito.

Até agora podemos notar que tanto Otlet quanto Briet já tinham em suas noções sobre documento, o germe da noção de informação, representada principalmente pela ideia de promoção e acesso à informação (ORTEGA; LARA, 2010).

Outro discípulo de Otlet que também trouxe a noção de informação no conceito de documento foi Escarpit (1976). Para ele o documento era um objeto informacional visível ou palpável, que possuía uma dupla independência em relação ao tempo: a sincronia (independência interna da mensagem e justaposição multidimensional de traços) e a estabilidade (independência global do objeto informacional, organizado num suporte material que pode ser reproduzido). Para o autor, sincronia e estabilidade se manifestavam a partir de três funções: a icônica (sincronia interna da mensagem visual para sua inscrição em um objeto estável), a discursiva (criação de uma imagem espacial estável em um discurso inscrito no tempo) e a documentária (estabilização do conjunto 
da mensagem sobre um suporte que a torne independente no tempo) (ORTEGA; LARA, 2010).

O tempo, portanto, acaba sendo compensado na constituição de um documento, podendo ser reintroduzido como um movimento para que a informação possa ser restabelecida ao destinatário, passando de uma justaposição sincrônica para uma sucessão diacrônica, produtora de informação (ORTEGA; LARA, 2010). Nesse viés, Escarpit toma o documento como meio de constituição de um saber, não mais restrito à visão cronológica e linear dos eventos, mas num olhar potencialmente exploratório chega a uma produção informacional nova.

Outro autor que também considera o caráter informativo para o termo documento é Meyriat (1981). Para ele o documento não é um mero dado, mas o produto de uma vontade, voltado a informar ou se informar. Meyriat enuncia que o documento pode ser definido como um objeto que dá suporte à informação, servindo para comunicar e tendo caráter durável. Tal enunciação opera a partir de duas noções conjuntas e inseparáveis: uma de natureza material (objeto como suporte), e outra conceitual (valor de conteúdo da comunicação, ou seja, informação) (ORTEGA, LARA, 2010). Assim, para ele, toda mensagem possui uma significação, e não seria possível definir qualquer documento sem que se considerasse o significado da mensagem a ser transmitida. Além disso, outro ponto a ser considerado seria a vontade de se obter uma informação. Para o autor, um objeto pode ser considerado documento, mesmo que a vontade de seu criador seja outra, logo a definição de documento não se impõe como uma evidência inicial, mas depende dos pontos de vista e dos métodos documentários para ser compreendida.

Sob a perspectiva acima, verificamos que uma das principais noções ressaltadas por Meyriat é a questão de como um objeto se torna documento. Se por um lado afirma que nem todo objeto tem originalmente a função de se tornar um suporte de informação, por outro afirma que tal função pode lhe ser atribuída em determinado contexto, mesmo que sua função original seja outra. Conclui assim, que o documento teria uma dupla origem, já que ele pode ou não ter sido criado para tal função. Diante disso, seria no momento em que se busca informação que um determinado objeto se faz documento (ORTEGA; LARA, 2010). 
Meyriat nesse ponto retoma o viés de Briet, ao entender que qualquer coisa pode tornar-se um documento, ou seja, "produzir" informação. Mas para isso deve-se reconhecer primeiramente o documento como um objeto potencialmente significante, o que exige um trabalho de interpretação. Esse trabalho pode ser encarado sob duas visões: o documento por intenção e o documento por atribuição. O primeiro diz respeito ao documento que foi produzido com a intenção de ser informativo, já o outro é aquele que originalmente foi criado para outra finalidade, mas que pode assumir tal valor informativo. Observa-se assim que qualquer objeto pode tornar-se um documento, mas não quer dizer que tem por função "normal" servir de suporte à informação. Assim, o documento não deve ser associado apenas a um dado, mas ao produto de uma vontade, a de informar e a de se informar (MEYRIAT, 1981).

Outro autor de destaque é Estivals (1978), que juntamente com Meyriat e outros especialistas de diferentes campos do saber, faziam parte de um grupo de pesquisa ${ }^{7}$ voltado ao estudo da escrita e do documento, que apresentou seus estudos no INFORCOM $^{8} \cdot$. Desse grupo havia basicamente duas visões: uma de caráter essencialista e idealista, que considerava que o conhecimento estava implícito nos textos, a "escrita como produto da subjetividade humana" (ESTIVALS, p.6, 1978), logo o documento seria toda mensagem fixada em um suporte. A outra, mais voltada a um viés pragmático, considerava que o conhecimento só existia no tempo momentâneo da decifração e da utilização do documento, ou seja, só existe quando "encontra seu usuário”. Enquanto a primeira visão era predominantemente dos bibliólogos, a segunda era dos documentalistas, que mesmo depois de um impasse causado pelas divergências de perspectivas, conseguiram chegar a um consenso, sendo que os primeiros acabaram aceitando que a existência do documento estaria vinculada a um receptor, que ao utilizálo extrairia dele a informação (“conhecimento útil”).

Fora do âmbito da Documentação e sob perspectiva diferente, Foucault (2002) associa o documento ao sistema social em que é produzido, com base na Sociologia do

\footnotetext{
${ }^{7}$ Esse grupo era formado por especialistas de diferentes áreas: Pierre Albert (Informação e Impressão); Jean Guenot (Literatura e Edição); Jean Marie Bouvaist (Edição e Economia); Jacques Breton (Bibliologia); Meyriat (Documentação), e outros (ESTIVALS, p.32, 1978).

${ }^{8}$ INFORCOM foi um Congresso Nacional francês, organizado pela Societé des Sciences de l'Information et de la Communication e realizado em 1978 em Compiègne e em 1980 em Bordeaux (ESTIVALS, p.32, 1978).
} 
Conhecimento de Manheim ${ }^{9}$ (1952), além de aproximar o conceito de documento à informação. Ao criticar a ideia de que o documento continha uma mensagem nele mesmo, significando per si, Foucault discutiu o que seria necessário para um escrito tornar-se documento. Para isso repensou o papel do documento na História, muitas vezes encarado a fim de memorizar alguns aspectos do passado, em detrimento de outros, e com isso silenciando outras "vozes potenciais de informação". Questionou assim, o caráter de "verdade" apresentado pelo documento, ou mesmo a crença de que um documento possuía uma mensagem em si, dando como exemplo clássico o livro (LUND, 2009).

A partir dessas indagações acerca do valor de documento dado a um objeto, Foucault ampliou a discussão para um contexto histórico-social. Desenvolveu assim uma Teoria Geral do Documento em que procurava entender o papel do documento dentro de um sistema social, não só o seu valor como prova documental, mas o significado que lhe era atribuído socialmente, fruto de escolhas nem sempre isentas de ideologias e crenças de determinados grupos sociais. Seus trabalhos, nesse viés, serviram de base para outros autores, como Latour, na França e Brown e Duguid nos EUA (LUND, 2009).

Abaixo uma primeira síntese das principais noções do termo documento para os autores da linha francófona:

\begin{tabular}{|l|l|l|}
\hline Autores francófonos & Datas & Síntese dos conceitos de Documento \\
\hline Otlet & 1934 & Qualquer coisa em que o conhecimento \\
& & $\begin{array}{l}\text { pudesse ser registrado. } \\
\text { Meio de transmissão de dados } \\
\text { informativos ao conhecimento dos } \\
\end{array}$ \\
& interessados, que alijados no tempo e no \\
& espaço, poderiam ser mostrados os \\
\hline
\end{tabular}

\footnotetext{
${ }^{9}$ Karl Manheim (1893-1947) foi um sociólogo alemão que desenvolveu estudos sobre a Sociologia do Conhecimento. Primeiramente diferenciava objetos naturais e objetos culturais, subdividindo-os em três tipos de significado: objetivo, expressivo e documentário. O primeiro poderia ser facilmente estabelecido sem considerar a intenção ou a consciência do artista. $\mathrm{O}$ segundo em contrapartida precisava desses dois elementos anteriores para compreender o que motivara o artista a fazer o objeto. E o terceiro era fruto da interpretação documental, em que o objeto tornado documento tinha um lugar de significação no mundo social (LUND, p.407, 2009).
} 


\begin{tabular}{|c|c|c|}
\hline & & vínculos inteligíveis das coisas. \\
\hline Briet & 1951 & $\begin{array}{l}\text { Signo indicial de natureza concreta ou } \\
\text { simbólica, que poderia ser preservado } \\
\text { ou registrado para fins de representação. }\end{array}$ \\
\hline Escarpit & 1976 & $\begin{array}{l}\text { Documento é um objeto informacional } \\
\text { visível, que possui uma dupla } \\
\text { independência em relação ao tempo, a } \\
\text { sincronia e a estabilidade. } \\
\text { Documento como meio de constituição } \\
\text { de um saber. }\end{array}$ \\
\hline Estivals & 1978 & $\begin{array}{l}1^{\circ} \mathrm{O} \text { documento seria toda mensagem } \\
\text { fixada em um suporte (visão } \\
\text { essencialista). } \\
2^{\circ} \mathrm{O} \text { documento só existe quando } \\
\text { "encontra seu usuário". (visão } \\
\text { pragmática). }\end{array}$ \\
\hline Meyriat & 1981 & $\begin{array}{l}\text { O documento não é um mero dado, mas } \\
\text { o produto de uma vontade, voltado a } \\
\text { informar. } \\
\text { O documento por intenção é aquele que } \\
\text { foi produzido com a intenção de ser } \\
\text { informativo. Já o documento por } \\
\text { atribuição é aquele que originalmente } \\
\text { foi criado para outra finalidade, mas que } \\
\text { pode assumir esse valor informativo. }\end{array}$ \\
\hline Foucault & 2002 & $\begin{array}{l}\text { Procura entender o papel do documento } \\
\text { dentro de um sistema social, não só o } \\
\text { seu valor histórico de prova } \\
\text { documental, mas o significado que lhe é } \\
\text { atribuído socialmente. }\end{array}$ \\
\hline
\end{tabular}

Quadro 1-Síntese dos autores francófonos para o termo documento 


\subsubsection{Autores espanhóis}

A noção de documento no século XX na Espanha, assim como na França, está atrelada ao estudo da Documentação. Enquanto a França, junto com a Bélgica, foi o berço da concepção clássica de documento enunciada por Otlet, a Espanha a partir da década de 70, teve um avanço considerável na Documentação, motivada pela valoração dos processos de documentação como elementos essenciais à atividade científica (ORTEGA, 2009b).

Lasso de La Vega foi um dos precursores dos estudos documentais na Espanha. Preocupado com os fundamentos e métodos do tratamento da massa documental, o autor escreveu diversos trabalhos entre 1947 e 1980 voltados à Documentação, o que lhe conferiu o status do teórico espanhol que mais falou sobre o tema (ORTEGA; LARA, 2010).

López Yepes foi outro importante autor do período, que com sua obra históricoconceitual Teoría de la Documentación (1978), traçou um panorama do termo documento a partir de suas origens etimológicas até o século XX. Além de trazer as raízes etimológicas do termo documento, ainda apresentava as principais correntes teóricas documentárias, o que permitiu que sua uma obra se tornasse clássica para a Documentação espanhola. Foi atualizada em 1995 e renomeada como La Documentación como disciplina: teoria e história.

Em outras obras, López Yepes amplia a discussão sobre documento trazendo diferentes nuances do conceito. No artigo Hombre y documento: del homo sapiens al homo documentador (1998), o autor faz uma reflexão antropológica sobre as implicações da utilização humana das tecnologias documentais, traçando uma trajetória do homo sapiens ao homo digitalis ${ }^{10}$. Nesse percurso, destaca o papel do homo digitalis, em especial, uma de suas manifestações a do homo documentalis, cidadão capaz de criar e consumir, responsavelmente, ciência e cultura, o que para o autor seriam importantes traços de um profissional do documento, no contexto da Sociedade do Conhecimento. Dessa forma, López Yepes parte da noção genérica de documento como uma

\footnotetext{
${ }^{10} \mathrm{O}$ autor apresenta uma trajetória antropológica que começa no homo sapiens (primeiro homem da era da comunicação, também denominado homem da palavra escrita); o homo videns (homem da era da imagem) e homo digitalis (homem da época da revolução da informação, influência das tecnologias e internacionalização do mundo) (LOPÉZ YEPES, 1998).
} 
objetivação de uma mensagem em um suporte, para enfatizar sua função como elemento chave para a mediação cultural.

No outro artigo Reflexiones sobre el concepto de documento ante la revolución de la información: un nuevo profesional del documento? (1997), López Yepes para definir o conceito de documento faz um retrospecto da evolução etimológica do termo e discute como caracterizar tal conceito diante do cenário da sociedade atual. Quando perpassa pela evolução semântica do conceito documento, o autor tenta delimitar quatro principais noções do termo no contexto contemporâneo: como instrumento de cultura (meio de acumulação de dados e conhecimentos de uma determinada comunidade); como fixação de uma realidade (caráter do documento como memória exomática que reproduz nossa atividade mental); documento como instrumento de comunicação ou mensagem (portador e transmissor de mensagens registradas e recuperáveis, sujeitas à transformação); documento como fonte de um novo conhecimento científico (documento científico com valor de prova e testemunho). (LÓPEZ YEPES, 1997)

Sagredo Fernández e Izquierdo Arroyo (1982) também apresentam em seu artigo um retrospecto das noções de documento, com a diferença que se aprofundam na evolução etimológica e semântica do termo, resgatando suas raízes gregas, latinas e espanholas, além de discutir as principais tipologias documentais. Para isso os autores tomam como ponto de partida a noção do documento como palavra (termo) e como objeto (entidade), propondo para a compreensão do conceito três perspectivas: a filológica, estudo etimológico e semântico a partir das vertentes semasiológica e onomasiológica; a construtivo-funcional, que ressalta o papel do documento em relação aos elementos do modelo de comunicação humana (emissor, receptor, mensagem, código, canal, ruído) e o contexto em que está inserido; e o caráter normal, que segundo os autores é o papel de levar a síntese das menções e usos do documento na Documentação (SAGREDO FERNÁNDEZ; IZQUIERDO ARROYO,1982).

Essa noção de uso é retomada no texto Concepción lógico-linguística de la Documentación (1983) em que os autores Sagredo Fernández e Izquierdo Arroyo (1983) enunciam que a ideia de documento estaria fortemente vinculada ao uso, ou seja, seria a partir do uso que se conferiria o caráter documental, perspectiva próxima a de Meyriat. Dessa forma, o documento seria em si um objeto manufaturado (registrado em 
um suporte) e "mentefaturado" (a mente que geraria o conteúdo significativo), podendo assim funcionar tanto como documento como objeto (ORTEGA; LARA, 2010).

Martinez-Comeche (2000), também destacado por Ortega (2009b) e Lund (2009), traz outra perspectiva interessante da noção de documento. O autor divide a função documental a partir dos espaços de informação mais tradicionais: no arquivo, por exemplo, o documento se referiria a um evento, processo ou ato administrativo ou legal, caracterizado para se expressar em um meio em que foi gerado; na biblioteca, o documento poderia ser uma simples cópia de livro, ou seja, qualquer material em que tivesse registrado o pensamento humano, tornando-se assim a memória materializada da humanidade; e no museu qualquer objeto que relatasse a natureza ou o estado humano poderia ser denominado documento.

Segundo Lund (2009), tais afirmações o fazem concluir que teoricamente qualquer coisa poderia ser documento, algo que já fora abordado por Briet, anteriormente. Porém, para Martinez-Comeche (2000) nada é documento até se considerar seu caráter incorporado através da linguagem. Baseado na semiótica de Peirce, o autor enxerga o documento como uma mensagem icônica ou simbólica permanentemente incorporada ao meio e usado por um emissor/mediador/receptor vinculada a uma proposta informativa.

Outro autor que parte dos estudos da linha espanhola é o mexicano Rendón Rojas. Inicialmente, retoma Briet (1951) dizendo que o termo documento é "toda base de conhecimento expressa em um suporte material e suscetível de ser utilizada para consulta, estudo e prova" (RENDÓN ROJAS, p.120, 2005). Todavia, tal definição trazia problemas por conta de sua amplitude, e o autor portanto, tentando delimitar o conceito, fala de uma necessidade de se restringir o uso do termo documento ao âmbito da Bibliotecología", decompondo assim o "ser documento" em três níveis. No primeiro, o objeto é tomado tal como é, ou seja, sem que tenha havido sua aparição ou tido uma intencionalidade de torná-lo documento; num segundo nível o objeto é transformado em documento pelo trabalho de especialistas, deixando de ser um objeto em si para tornar-se um objeto para outro; e no terceiro, após a ação de especialistas e

\footnotetext{
${ }^{11}$ Bibliotecología é a denominação dada à Biblioteconomia nos países de idioma espanhol na América Latina, com algumas influências da Documentação europeia (ORTEGA, 2010)
} 
de ser lançado num sistema, ganharia outra função, transmitindo informação, e para isso poderia ser representado e recuperado pelos usuários (ORTEGA; LARA, 2010).

O papel do usuário tem importante destaque para o autor, que afirma que a interrelação do documento-biblioteca-usuário, essencialmente voltada à satisfação das necessidades de informação do usuário, constituem o objeto da Bibliotecología. Nessa perspectiva, o usuário é considerado como um ser humano "ideal" ao poder exigir a satisfação de suas necessidades de informação, tendo assim o importante papel de criar e conectar-se com o mundo, tornando-se, para a Bibliotecología, a origem e o fim de suas atividades (RENDÓN ROJAS, 2005).

Além disso, Rendón Rojas (2005) destaca as principais características do termo documento: sua capacidade de conservar a memória social, sua função sóciocomunicativa; ser uma objetivação do pensamento, e o fato de estar semanticamente ligada à informação. Combinando essas características, o autor sintetiza dizendo que o documento seria um produto social e cultural, resultado de uma objetivação do espírito e do pensamento humano, que tem como principal objetivo preservar a memória social (RENDÓN ROJAS, 2005 citado por ORTEGA; LARA, 2010).

Dessa forma, percebemos que o autor não trabalha com a ideia de que a informação exista no objeto em si, mas que esteja vinculada à recepção. Assim como Briet, acredita que o 'ser documento' está relacionado ao lugar que o objeto ocupa em determinado contexto. Tal função é facilmente percebida através da ação intencional executada por um profissional da informação que representa os diferentes níveis de "ser documento", ao propiciar um "novo sentido" ao documento inicial colocando-o em outro contexto.

Para finalizar o rol de autores da linha espanhola é salutar falar do artigo de Silva (2006), que mesmo sendo português incorpora em seus estudos traços da Documentação francesa e espanhola, com destaque para esta última no trabalho citado. Em o Documento e informação: as questões ontológica e epistemológica, o autor não só conceitua os termos documento e informação, como os aproxima chegando até a propor o binômio documento-informação, como podemos ver a seguir: 
A essência do documento está, pois, naquilo que o faz ser como é, ou seja, no conteúdo, na informação. E, se levarmos, analiticamente, até às últimas consequências, a tónica da intenção comunicativa, temos de concluir que o documento é a cristalização através de registro tecnológico (fixar a escrita na pedra, no papiro, no pergaminho, no papel ou fixar texto e imagens num suporte digital) de uma intenção comunicativa que potencia uma efectiva situação comunicacional e, portanto, pode-se e deve-se inserir o binómio Documento - Informação no interior de outro mais abrangente - o binómio Informação-Comunicação porque estes tópicos são fundamentais no âmbito de uma epistemologia simultaneamente crítica e consolidadora da Ciência da Informação (SILVA, p.15, 2006).

Silva (2006), portanto compreende que a noção de documento está atrelada à materialização da informação, ou seja, seu registro em um suporte. Tal materialização traria em seu bojo o papel de potencializar a comunicação, mas apenas se constituindo a partir da interação completa entre emissor e receptor. Dessa forma, o documento estaria associado à "mutação do fenômeno da informação" no processo comunicacional, incorporando para isso aspectos interpessoais e coletivos de um determinado contexto.

Os autores espanhóis expostos anteriormente, assim como os franceses, partem da noção clássica de documento, apresentada pelo olhar otletiano, e incorporam novas nuances de significado. Nessa ótica, Ortega e Lara (2010), afirmam que a noção de documento proposta pelos primeiros documentalistas acaba sendo aprofundada e atualizada pelos autores franceses e espanhóis.

Abaixo uma síntese das principais noções do termo documento a partir dos autores de língua espanhola selecionados.

\begin{tabular}{|l|l|l|}
\hline Autores espanhóis & Datas & Síntese dos conceitos de Documento \\
\hline López Yepes & 1978 & $\begin{array}{l}\text { Documento como uma } \\
\text { objetivação de uma mensagem em } \\
\text { um suporte. } \\
\text { Destaque do papel do documento } \\
\text { como elemento chave para a } \\
\text { mediação cultural. } \\
\text { Documento como instrumento de } \\
\text { cultura; como fixação de uma } \\
\text { realidade; instrumento de } \\
\text { comunicação ou mensagem e }\end{array}$ \\
\hline
\end{tabular}




\begin{tabular}{|c|c|c|}
\hline & & $\begin{array}{l}\text { fonte de um novo conhecimento } \\
\text { científico. }\end{array}$ \\
\hline $\begin{array}{l}\text { Sagredo Fernández e } \\
\text { Izquierdo Arroyo }\end{array}$ & 1983 & $\begin{array}{l}\text { Noção do documento como } \\
\text { palavra (termo) e como objeto } \\
\text { (entidade). } \\
\text { Ideia de documento estaria } \\
\text { fortemente vinculada ao uso, ou } \\
\text { seja, seria a partir do uso que se } \\
\text { conferiria o caráter documental. }\end{array}$ \\
\hline Martinez-Comeche & 2000 & $\begin{array}{l}\text { Qualquer coisa poderia ser } \\
\text { documento, mas nada é } \\
\text { documento até ser considerado } \\
\text { como tal. (Ressalta o papel da } \\
\text { linguagem). }\end{array}$ \\
\hline Rendón Rojas & 2005 & $\begin{array}{l}\text { Documento como tudo aquilo que } \\
\text { possui uma expressão material e } \\
\text { representa certo fenômeno, } \\
\text { independente de sua natureza } \\
\text { material. } \\
\text { Documento em três níveis: } \\
\text { documento como um objeto em si; } \\
\text { objeto transformado em } \\
\text { documento por especialistas; e } \\
\text { podendo transmitir informação e } \\
\text { ser recuperado pelo usuário. }\end{array}$ \\
\hline Silva & 2006 & $\begin{array}{l}\text { A noção de documento está } \\
\text { atrelada à materialização da } \\
\text { Informação, ou seja, seu registro } \\
\text { em um suporte. }\end{array}$ \\
\hline
\end{tabular}

Quadro 2- Síntese dos autores espanhóis para o termo documento 


\subsubsection{Autores anglo-saxões e escandinavos}

É importante, antes de apresentar a perspectiva anglo-saxã e escandinava, relembrar que nos EUA no final da década de 60 e nos anos 70, o termo documento acaba praticamente sendo substituído pelo termo informação, resultado do surgimento do campo da Ciência da Informação. Enquanto na Europa o termo documento servia de base para diferentes estudos, principalmente na tradição francófona e espanhola, nos EUA, a ideia de documento estava associada à Antropologia e Sociologia. Segundo Lund (2009), Garfinkel (1967) e Smith (1974) nos EUA, por exemplo, tratava-se o documento a partir de métodos de estudo e da interpretação de dados, direcionando a pesquisa à análise em sistemas sociais.

Rayward é um dos primeiros pesquisadores americanos ${ }^{12}$ a recuperar a obra de Otlet e enxergar seu potencial para a Ciência da Informação. Dentre os vários pontos que ressalta da obra de Otlet, como atuais e visionários para a época do autor, destacamos, para os nossos propósitos, a noção de documento. Como já foi mencionado anteriormente, quando Otlet afirma que o documento é um registro de informação que independe do suporte (embora não exista sem ele), contribui com a ampliação do conceito, colocando-o, segundo Rayward (1991), no centro do complexo processo de comunicação, acumulação e transmissão do conhecimento.

Outro autor que redescobriu Otlet e também Briet nos EUA foi Buckland (1997). Para ele, a Documentação preocupou-se com os problemas de armazenamento e recuperação da informação, o que lhe fez focar-se na ideia de documento como termo genérico para indicar qualquer recurso informacional físico. No entanto, questionou tal generalização, retomando o exemplo do antílope de Briet, indagando-se qual seria nesse contexto um termo genérico o suficiente para incluir todas as coisas informativas de que podemos tratar. Diante disso, sugeriu a palavra 'discurso' como um termo melhor para indicar textos ou artefatos no sentido geral, além de ter incutido em seu bojo a ideia de “intenção de representar coisas” (ORTEGA, 2009b e LUND 2009).

\footnotetext{
${ }^{12}$ W. Boyd Rayward é de origem australiana, contudo desenvolve suas pesquisas e é professor nos EUA desde 1965, primeiro pela Universidade de Chicago, até a década de 80, depois na Universidade de New South Wales, até 2004 e desse período até hoje está na Universidade de Illinois. Disponível em: http://people.lis.illinois.edu/ wrayward/cv.html
} 
Houser (1986 apud LUND, 2009) é outro pesquisador que aproxima o termo documento de discurso, dizendo que o documento seria um discurso social registrado em um suporte e produzido de acordo com uma função linguística específica. No entanto, não menciona filmes ou registros sonoros, elementos presentes tanto em Otlet quanto em Briet. Já Levy (2002 citado por LUND, 2009) num âmbito mais abrangente, considerando o contexto digital, enuncia documento como aquilo que satisfaz uma necessidade de recursos estáveis, externos e comunicativos, o que segundo ele devem fundir tanto a ideia de armazenamento como de representação de um documento (LUND, 2009).

Em outro trabalho de destaque do autor, o artigo Fixed or fluid (1994), a discussão sobre o papel do documento no contexto digital é mais aprofundada. Primeiro Levy (1994) afirma que desde a origem os documentos surgem com a finalidade de, responder a uma necessidade humana básica, criando estabilidade num meio de constante mudança. Para isso, é importante definir características capazes de fixarem o que é significativo para ser fixado numa forma estável. Contudo o autor lembra que tal estabilidade, que permite a permanência no tempo e a distribuição no espaço, também possui um aspecto fluído, principalmente visualizado hoje a partir do caráter dinâmico tecnológico. Dessa forma, Levy (1994) prefere falar que os documentos, independentemente da tecnologia, são fixos e fluidos, já que a permanente tensão entre estes polos reflete, em última análise, o principal papel do documento, sua função como artefato social, fruto das necessidades humanas e do contexto.

Frohmann (2004) é outro autor que também partiu dos estudos dos documentalistas clássicos, mas explorou outra vertente, a filosófica, a partir dos estudos de Wittgenstein. Tal perspectiva, voltada às práticas documentárias (entendidas como práticas de produção literária em geral), propiciou um pensar filosófico, o que para Frohmann acarretou perceber que a documentação ${ }^{13}$ cobriria um terreno mais amplo que os próprios estudos informacionais. Dessa forma, constatou que a noção de

\footnotetext{
${ }^{13}$ A relevância dada por Frohmann à documentação é questionada em razão da abrangência dada ao termo 'práticas documentárias', mas que parece não incluir, como ocorre na documentação, o fenômeno da institucionalização da informação relacionado ao trato da massa documental como requisito para a comunicação documentária, visto como um processo de codificação e decodificação de conteúdos informativos. Logo, o destaque dado por Frohmann ao movimento documentalista clássico parece ressaltar antes a produção e uso dos documentos que os aspectos voltados às operações realizadas sobre o documento com fins de recuperação a partir do sistema (ORTEGA; LARA, 2010).
} 
informatividade dos documentos estaria associada às práticas documentárias, ou seja, a ideia de informatividade referia-se aos fatores que deveriam ser levados em conta para considerar o caráter informativo do documento.

Em outro texto, Frohmann (2006) retoma o conceito de materialidade do documento, elemento que segundo ele traz uma compreensão maior do caráter social e público da informação, já que por meio da documentação seria possível identificar o campo institucional, tecnológico, político e cultural, a fim de configurar a diversidade de aspectos da informação na atualidade. Baseando-se nos estudos de Foucault, que ressalta o papel da documentação em relação ao da comunicação da informação, Frohmann enxerga a documentação funcionado como uma ponte entre o discurso e os estudos da materialidade da informação, fazendo com que as práticas documentais institucionais forneçam à informação elementos que permitam sua configuração num contexto social.

No artigo Documentation redux: prolegomenon to (another) philosophy of information, Frohmann (2004) ressalta a importância das práticas documentárias no contexto digital. Contrário a autores como Capurro, Floridi e Elred que superestimam o papel da informação na era digital, Frohmann destaca o papel das práticas documentárias nesse contexto (ORTEGA, 2009c). O autor afirma que a forma digital dos documentos contemporâneos não cria imperativos filosóficos específicos, ou seja, a noção de documento eletrônico traz antes de tudo o conceito de documento, que independente do formato, tipologia ou manifestação ratifica a essência da natureza documental.

Outros trabalhos também tratam sobre o documento na era digital, dos quais podemos destacar os trabalhos de Brooks, a exemplo do paper Where is meaning when form is gone? (2001apud LUND, 2009), em que questiona se devemos, realmente, no contexto da $2^{\text {a }}$ geração da $w e b$, abandonar o "paradigma do documento", substituindo-o simplesmente por informação, se no bojo de vários elementos do mundo digital, revisitamos a essência da noção de documento (LUND, 2009). Assim, Brooks relembra as noções visionárias de Otlet, que agora se concretizam com a web e o hipertexto, e salienta que a noção de documento é revisitada na contemporaneidade, acomodando-se às nuances da web, e aproximando-se de seus conceitos-chave, a exemplo da própria noção de metadados ("representação da informação"). 
Lund (2009) em seu artigo Document Theory, além das correntes mais tradicionais do estudo do documento, francesa, espanhola e anglo-saxã, também retoma importantes trabalhos de autores escandinavos, pouco conhecidos. De modo geral aponta que a literatura anglo-escandinava, mais voltada à comunidade da Library and Information Science (LIS), principalmente após a década de 80, enfatiza principalmente duas perspectivas acerca do documento: a questão da materialidade e o seu papel social numa determinada comunidade.

$\mathrm{Na}$ primeira perspectiva temos dois exemplos: Shillingsburg e Haley. Shillingsburg (1991 apud LUND, 2009) ressalta a materialidade do documento definindo-o como objeto físico e material que pode estar "seguro entre as mãos", desconsiderando assim o impacto da tecnologia digital para sua definição. Hayle (2003 apud LUND, 2009), em contrapartida, considerando tal caráter, afirma que a noção de documento deveria passar por diferentes nuances de sentido, que permitiriam que o documento tivesse uma interpretação distinta para cada leitor.

Voltada à perspectiva social podemos enfatizar três autores, destacados por Lund (2009): Suominen, Andersen e Hjorland. A primeira, pesquisadora finlandesa, em sua dissertação Filling Empty Space (1997), toma o documento como uma mensagem que possui "alguma permanência", fato que lhe confere uma diversidade de uso, e que é resultado de uma história e de um contexto comunicacional, fatores que inserem o documento numa esfera cultural. Além disso, a autora retoma a ideia de recuperação da informação e as estruturas semióticas para utilizá-las na busca documentária.

Andersen (2006 apud LUND, 2009), a partir dos estudos de Habermas (1989) sobre a noção de esfera pública, desenvolve uma teoria de organização social do documento e do conhecimento, conforme destaca Lund (2009). Fala da diversidade de gêneros documentais na sociedade e da dificuldade em se lidar tanto na esfera pública como na privada com tal elemento, bem como considerar os diferentes domínios que se incorporam ao contexto documental. Já Hjorland (2001 apud LUND, 2009), numa visão mais sócio-cultural do documento, ressalta o valor de estabilizar formas e práticas. Para ele a natureza intrínseca de um objeto é relativamente irrelevante, já que um objeto se torna documento somente quando assume um valor informativo para uma coletividade ou domínio (LUND, 2009, p.414). 
Abaixo a síntese das noções de documento a partir da seleção de autores anglosaxões e escandinavos.

\begin{tabular}{|c|c|c|}
\hline Autores anglo-saxões e escandinavos & Datas & Síntese dos conceitos de Documento \\
\hline Houser & 1986 & $\begin{array}{l}\text { Documento seria um discurso } \\
\text { social produzido de acordo com } \\
\text { uma função linguística específica, } \\
\text { e que poderia ser registrado em } \\
\text { um suporte. }\end{array}$ \\
\hline Rayward & 1991 & $\begin{array}{l}\text { Documento como um registro de } \\
\text { informação, que independe do } \\
\text { suporte, podendo ser considerado } \\
\text { no centro do complexo processo } \\
\text { de comunicação, acumulação e } \\
\text { transmissão do conhecimento. }\end{array}$ \\
\hline Buckland & 1997 & $\begin{array}{l}\text { Documento como termo genérico } \\
\text { para indicar qualquer recurso } \\
\text { informacional físico. } \\
\text { Termo genérico o suficiente para } \\
\text { incluir todas as coisas } \\
\text { informativas de que podemos } \\
\text { tratar, para isso sugeriu a palavra } \\
\text { 'discurso'. }\end{array}$ \\
\hline Levy & $\begin{array}{l}1994 \\
2002\end{array}$ & $\begin{array}{l}\text { Principal papel do documento: sua } \\
\text { função como artefato social, fruto } \\
\text { das necessidades humanas e do } \\
\text { contexto. } \\
\text { Documento como aquilo que } \\
\text { satisfaz uma necessidade de } \\
\text { recursos estáveis, externos e } \\
\text { comunicativos. }\end{array}$ \\
\hline Frohmann & 2004 & $\begin{array}{l}\text { Noção de informatividade dos } \\
\text { documentos estaria associada às } \\
\text { práticas documentárias. }\end{array}$ \\
\hline
\end{tabular}




\begin{tabular}{|l|l|l|}
\hline & 2006 & $\begin{array}{l}\text { A ideia de informatividade refere- } \\
\text { se aos fatores que devem ser } \\
\text { levados em conta para que um } \\
\text { documento torne-se informativo. }\end{array}$ \\
\hline $\begin{array}{l}\text { Lund } \\
\text { Materialidade:Shillingsburg(1991) } \\
\begin{array}{l}\text { Haley (2003). } \\
\text { Papel social: Suominen(1997), } \\
\text { Andersen(2006) e Hjorland(2001). }\end{array}\end{array}$ & 2009 & $\begin{array}{l}\text { Documento visto sob dois } \\
\text { aspectos: a perspectiva da } \\
\text { materialidade o seu papel social } \\
\text { numa determinada comunidade. }\end{array}$ \\
\hline
\end{tabular}

Quadro 3- Síntese dos autores anglo-saxões e escandinavos para o termo documento

\subsection{Noções do termo "informação"}

\subsubsection{Autores anglo-saxões e escandinavos}

Uma das acepções clássicas do termo informação, no âmbito da Ciência da Informação é a de Buckland (1991). Ele distingue três significados para o termo: informação como processo, como conhecimento e como coisa. No primeiro caso destaca o ato de informar como um sinônimo de comunicar um conhecimento ou algum fato. Já a informação como um "conhecimento comunicado", seria aquilo capaz de reduzir incertezas e com isso gerar conhecimento. E a informação como coisa poderia ser atribuída a qualquer objeto, dado ou documento que tivesse a propriedade de comunicar algo, divulgar o conhecimento, "ser informativo".

A partir de tais noções, Buckland (1991) fala da questão do tangível e do intangível da informação. Enquanto a informação como conhecimento é totalmente intangível e imensurável, a informação como coisa, por ser tangível, permite a descrição e expressão da informação como conhecimento. Mesmo que a denominação genérica de "coisa" traga em seu bojo diversas possibilidades de elementos que possam ser considerados informação, a enunciação de Buckland trouxe duas importantes discussões para área da Ciência da Informação: a indicação de uma natureza subjetiva do termo e 
principalmente e reintrodução do conceito de documento ${ }^{14}$ no âmbito da Ciência da Informação por meio do conceito de informação como coisa.

Sob outro aspecto, Wersig e Windel (1985) consideram a realidade social nos estudos informacionais. Para eles, as práticas informacionais ocorrem entre um sujeito duplamente gerador e receptor da informação que utiliza um "equipamento prévio" que lhe capacita à "comunicação/ação". A intermediação entre o campo da consciência e o campo da ação, é feita através da orientação e delimitação da atividade do sujeito, que por tais fatores atua de forma intencional e consciente. Assim, a informação funcionaria como um redutor de incerteza, ou seja, um elemento capaz de resolver uma situaçãoproblema.

Contrários à vertente naturalista que enxerga o fenômeno informacional como natural o que acaba negando ou reduzindo a dimensão ativa e intencional do sujeito, Wersig e Windel (1985) ressaltam o papel das situações sociais de cooperação e conflito para se enxergar a informação. Nessa perspectiva, o fenômeno informacional seria reconstruído pelo sujeito cognitivo-social, o que daria à informação um status de algo aberto e inacabado sempre propício à reestruturação do sujeito do conhecimento. $\mathrm{O}$ único senão, apontado por Araújo (2002) nessa perspectiva, seria o fato de se desconsiderar as possibilidades de a informação também gerar incertezas, a exemplo da falta de compreensão do sujeito, ou mesmo sobrecarga informacional (ARAÚJO, 2002).

Lyotard (1990), também numa tentativa de compreender o conceito de informação, encara o termo sob duas abordagens: uma sistêmica e outra pós-moderna. $\mathrm{Na}$ primeira destaca a função da informação como garantia de estabilidade para um determinado sistema social, o que confere a ela um caráter essencialmente operacional. Já na abordagem pós-moderna, Araújo (2002) enxerga duas funções: uma como mediadora dos processos de apreensão da realidade e das relações sociais; e outra como um elemento que adquire característica de "mercadoria", pois se torna indispensável para a força produtiva contemporânea.

\footnotetext{
${ }^{14}$ As obras clássicas da Documentação, hoje revisitadas à luz da Ciência da Informação, foram praticamente ignoradas no âmbito anglo-saxão, até os trabalhos de Buckland e Rayward, que trouxeram à tona as obras de Otlet. No entanto, até hoje o clássico do autor, Traité de Documentation (1934) ainda não foi traduzido para o inglês (ORTEGA, 2004).
} 
Sobre a visão sistêmica, Araújo (2002) comenta que por ser essencialmente calcada na mensagem e influenciada pela Teoria Matemática de Shannon e Weaver (1947), tem como principal problema o fato de desconsiderar a influência do contexto social nas práticas informacionais, bem como o papel do sujeito como mencionado anteriormente. Além disso, com o advento da Teoria Crítica, a exemplo dos estudos de socialização da informação de Habermas, a ideia de informação assume uma dimensão política, econômica, cultural e histórica a partir do final da década de 1920.

Quanto à visão pós-moderna, há outra interpretação da função da informação no âmbito contemporâneo. Para Lyotard (1990), o indivíduo não entra em contato direto com a informação a partir de sua práxis, mas pela informação que é veiculada pelos diferentes canais disponíveis a ele (comunicação eletrônica, comunicação de massa, base de dados, etc). Deste modo, ao contrário da primeira acepção que considera a informação como algo que permite estabilidade ao sistema, nota-se na verdade um papel de mediação dos processos de apreensão do real a partir das relações sociais, algo de difícil mensuração e controle (ARAÚJO, 2002).

Sob outra perspectiva, Brier (p. 188, 1998) ressalta que para uma "definição frutífera" de informação devem ser considerados tanto seus aspectos objetivos como subjetivos. Assim, observa que a percepção e a interpretação das palavras força as escolhas que darão as oportunidades de ação e concepção de significado. Dessa forma, considera complementarmente o modelo de transmissão, onde "pacotes de informação" são enviados através de uma linguagem de um remetente para um receptor, e o momento da interpretação do conceito, produto de um contexto histórico-social e que está, portanto, em constante desenvolvimento (BRIER, 1998).

McGarry (1999), a partir dos estudos da Teoria da Informação e da Comunicação, enuncia informação como algo que é capaz de alterar os mapas/estruturas mentais. Oposta à incerteza, a informação seria o elemento de que necessitamos quando nos deparamos com uma escolha, funcionando como uma "medida de liberdade" na seleção de mensagens. Para isso, a informação deve ser ordenada e estruturada para ser discriminável para o receptor a partir de alguma forma de veículo de transmissão, sinais, símbolos, ou signos.

As classes de veículos de transmissão mencionadas por McGarry (1999) enfatizam a função de modos necessários para o intercâmbio e transferência da 
informação que podem assumir diferentes formas, ressaltando assim o poder da linguagem no domínio informacional. Deste modo, mesmo retomando o valor da informação comunicada, observa-se que o autor destaca o papel da linguagem na compreensão do fenômeno informacional. Parte da caracterização da linguagem humana e seu papel na rede de relações, à relação linguagem/pensamento, entidades interdependentes que corroboram a compreensão dos conceitos de conhecimento e informação.

McGarry (1999) conclui, em seu capítulo Sobre Conhecimento e Informação, que é difícil distinguir esses dois termos, dizendo até que em alguns contextos podem ser intercambiáveis. Porém, na tentativa de explicitar uma síntese afirma que o conhecimento é algo mais teórico e generalizado, e a informação seria um “conhecimento potencial". Assim, atribuímos significado ao identificar e relacionar classes de eventos, agrupando-as ou separando-as conforme suas similaridades e distinções, a partir de nossa capacidade de produzir, compartilhar e transmitir informações.

Capurro $^{15}$ (2007), fortemente embasado numa abordagem histórica, filosófica e epistemológica da Ciência da Informação, é um dos autores contemporâneos que mais se detém na compreensão do conceito de informação. Num artigo de 2007 com Hjorland, por exemplo, retoma o trabalho de Schrader (1983 apud CAPURRO; HJORLAND, 2007) que pesquisou cerca de 700 definições do termo informação, no período entre 1900 a 1981, chegando à conclusão de que não há um consenso para a definição do termo. A razão é facilmente justificável, já que seu teor interdisciplinar não respeita as fronteiras das disciplinas, variando de significado conforme a área de conhecimento, o que dificulta uma consolidação (CAPURRO; HJØRLAND, 2007).

Nesse mesmo artigo, os autores mostram as diferentes acepções do termo informação partindo da análise de suas raízes etimológicas, perpassando pelo seu uso moderno e pós-moderno, além de se deterem na análise do conceito nas áreas das ciências naturais, cognitivas, sociais e da informação. Em outro artigo, Epistemologia e Ciência da

\footnotetext{
${ }^{15}$ Rafael Capurro teve uma formação híbrida. De nacionalidade uruguaia (Montevidéu, 1945), graduou-se em Filosofia na Argentina (Buenos Aires, 1970), fez doutorado (Frankfurt, 1978) e pós-doutorado (Düsseldorf, 1989) na Alemanha, onde desde então reside e é professor. No âmbito deste trabalho, como grande parte de seus artigos foram publicados em alemão ou inglês, optou-se por colocá-lo entre os autores anglo-saxões com esta pequena ressalva de suas origens (MATHEUS, p. 143, 2005).
} 
Informação de 2007, Capurro se dedica a pormenorizar a análise do termo informação, enxergando-o sob três paradigmas: o físico, o cognitivo e o social.

O paradigma físico da informação, no âmbito da Ciência da Informação, está intimamente ligado à Teoria da Informação de Shannon e Weaver (1949), à Cibernética de Wiener (1961) e coincide com o início da Ciência da Informação, muito associada à Information Retrieval. Segundo Capurro (2007) tal paradigma refere-se a um objeto físico que um emissor transmite a um receptor. Shannon, em sua teoria, designava o objeto como mensagem ou sinal, assumindo uma visão quantitativa de seleção de um repertório de símbolos físicos que poderiam ser reconhecidos pelo receptor.

O paradigma cognitivo por sua vez está relacionado à Ontologia e a Epistemologia de Popper (1973 citado por CAPURRO; HJORLAND, 2007) e aos estudos dos estados anômalos do conhecimento de Belkin (1980), Brookes (1980) e Irgwersen (1992), conforme apontam Capurro e Hjorland, (2007). Popper, ao falar da perspectiva dos três mundos ${ }^{16}$, destaca o terceiro como o responsável pelos conteúdos intelectuais, com o papel de "representar" os objetos inteligíveis dos dois outros mundos, tendo assim uma proximidade com a ideia de signo peirceano (SKAGESTAD, 1993 apud CAPURRO; HJØRLAND, 2007). Já a teoria do estado anômalo do conhecimento pressupõe que a busca por informação se origine de uma necessidade de um indivíduo em solucionar um problema, ou seja, resolver uma anomalia em seu estado de conhecimento. Nesse viés, Brookes (1980) ressalta o papel da informação como um elemento que provoca transformação nas estruturas mentais do sujeito cognoscente, tomada como uma prática social que envolve ações de atribuição e comunicação de sentido.

Já o paradigma social, o qual Capurro (2007) defende, é influenciado pela Hermenêutica de Heidegger (1973), e a proposta dos Jogos de Linguagem de Wittgenstein (1958), ambos os críticos da separação entre o sujeito cognoscente encapsulado e o mundo exterior. Diferente do paradigma cognitivo, voltado isoladamente ao sujeito num contexto ideal, o paradigma social considera os processos sociais de produção, distribuição e intercâmbio de informação no meio social. O

\footnotetext{
${ }^{16}$ Popper (1973), numa perspectiva ontológica, divide o mundo em três partes: o primeiro mundo, formado de objetos ou estados físicos; o segundo constituído de estados psíquicos e da consciência; e o terceiro, formado por elementos inteligíveis que representam um conteúdo de informação. $\mathrm{O}$ autor nesse caso usa as palavras conhecimento e informação como termos intercambiáveis (CAPURRO; HJØRLAND, p.190, 2007).
} 
paradigma social está diretamente relacionado às comunidades discursivas, resultando numa dedicação efetiva às relações entre os discursos, áreas de conhecimento, documentos e as distintas comunidades de usuários.

Hjorland (2007), que também defende uma perspectiva subjetiva da informação, em seu artigo Information: objective or subjective/situational? traz primeiramente a visão objetiva, defendida por Parker, Dretske Stonier, e Bates, e depois contrapõe com a subjetiva, defendida por Bateson, Yovits, Spang-Hanssen, Brier, Buckland, Goguen, e ele mesmo. Na primeira ressalta a definição de Bates (2006 citado por HJORLAND, 2007), que encara a informação como um padrão de organização da matéria e da energia, enquanto no aspecto subjetivo/situacional, a informação desempenha diferentes papeis, já que está atrelada às organizações sociais e a diversidade de contextos. Enquanto o primeiro aspecto procura mapear os valores da informação numa perspectiva objetiva, o segundo deve considerar as relações entre o objeto informativo, as estruturas informacionais, a linguagem das comunidades discursivas e o contexto, para daí esboçar um valor informativo.

A seleção do que é informativo não é algo simples de ser mensurado, pois há problemas de consenso de critérios e paradigmas entre domínios e áreas diversas. Mesmo assim, há autores que preferem considerar as possibilidades de se informar, a informatividade, ao invés de deterem-se ao termo informação. Nesse caso, destaca-se o aspecto pragmático, considerando os processos de recepção da informação em situações de uso. Frohmann (2004), por exemplo, preferia usar o termo informatividade, ressaltando seu valor potencialmente adquirido em determinado contexto discursivo. $\mathrm{O}$ termo informatividade, de origens na Linguística Textual, assume um significado semelhante ao de intertextualidade no âmbito da Ciência da Informação, ressaltando o fato de que a compreensão de um texto é dependente do conhecimento de outros textos (ORTEGA; LARA, 2010).

Abaixo a síntese das principais noções do termo informação para os autores anglo-saxões e eslavos

\begin{tabular}{|l|l|l|}
\hline $\begin{array}{l}\text { Autores anglo-saxões e } \\
\text { escandinavos }\end{array}$ & Datas & Síntese do conceito de Informação \\
\hline Wersig e Windel & 1985 & $\begin{array}{l}\text { Informação como um redutor de incerteza, } \\
\text { elemento capaz de resolver uma situação- } \\
\text { problema. }\end{array}$ \\
\hline
\end{tabular}




\begin{tabular}{|c|c|c|}
\hline Lyotard & 1990 & $\begin{array}{l}\text { Visão sistêmica-informação como garantia de } \\
\text { estabilidade do sistema. } \\
\text { Visão pós-moderna- informação mediadora } \\
\text { dos processos de apreensão das relações } \\
\text { sociais ou como valor de "mercadoria", base } \\
\text { para a força produtiva. }\end{array}$ \\
\hline Buckland & 1991 & $\begin{array}{l}\text { Informação como processo (comunicar algo); } \\
\text { Informação como conhecimento (reduzir } \\
\text { incertezas e gerar conhecimento) } \\
\text { Informação como coisa (propriedade de } \\
\text { comunicar algo e ser informativo). }\end{array}$ \\
\hline Brier & 1998 & $\begin{array}{l}\text { Os "pacotes de informação" são enviados } \\
\text { através de uma linguagem de um remetente } \\
\text { para um receptor, e o momento da } \\
\text { interpretação do conceito é produto de um } \\
\text { contexto histórico-social em } \\
\text { desenvolvimento. }\end{array}$ \\
\hline McGarry & 1999 & $\begin{array}{l}\text { Informação como algo que é capaz de alterar } \\
\text { os mapas/estruturas mentais } \\
\text { (Informação tomada como conhecimento } \\
\text { potencial). }\end{array}$ \\
\hline Frohmann & 2004 & 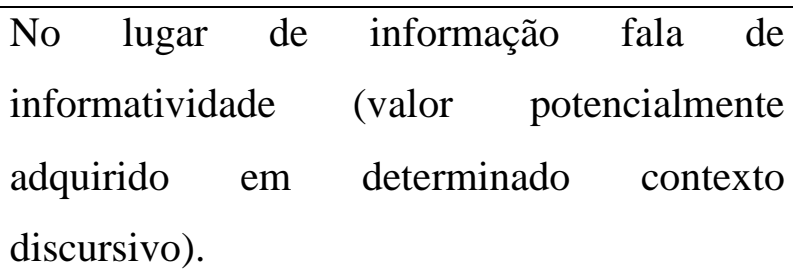 \\
\hline Capurro/ Hjorland & 2007 & $\begin{array}{l}\text { Paradigma físico- informação como um } \\
\text { objeto físico que um emissor transmite a um } \\
\text { receptor. } \\
\text { Paradigma cognitivo- informação como } \\
\text { elemento que provoca transformação nas } \\
\text { estruturas mentais do sujeito cognoscente. } \\
\text { Paradigma social- considera os processos de } \\
\text { produção, distribuição e intercâmbio de }\end{array}$ \\
\hline
\end{tabular}




\begin{tabular}{|l|l|l|}
\hline Hjorland & 2007 & $\begin{array}{l}\text { informação no meio social. } \\
\text { Considera o aspecto objetivo da informação } \\
\text { (como padrão de organização da matéria e da } \\
\text { energia) e o aspecto subjetivo (com valor } \\
\text { informativo, fruto da análise das relações } \\
\text { entre o objeto informativo, as estruturas } \\
\text { informacionais, a linguagem das comunidades } \\
\text { discursivas e o contexto). }\end{array}$ \\
\hline
\end{tabular}

Quadro 4- Síntese dos autores anglo-saxões e escandinavos para o termo informação

\subsubsection{Autores francófonos}

Um autor que traz outras perspectivas para falar do termo informação, associando-o ao termo documento, é Michel (2000). Para isso inicialmente retoma a definição de informação numa imagem puramente subjetiva, alguma coisa que em um determinado contexto e a partir de determinado olhar "significa". Num segundo momento fala da materialização desse olhar subjetivo através do documento (fisicamente real e / ou eletrônico-virtual), que teria a função de "congelar" a informação para que pudesse ser "trocada". E por último, associando-a à demanda profissional, afirma que atualmente somos levados a falar de informação-documentação (I\&D), expressão que teria o mérito de mostrar os dois lados de um mesmo conceito: em uma face o conteúdo, o sentido e a inteligência (informação) e do outro aquilo que comunica, transfere, e é obtido através de um suporte (documento).

Outra vertente de pensamento, mais associada à linha anglo-saxônica é a de Frochot (2003), que sintetiza duas definições para a informação: uma de caráter objetivo e outra subjetiva. Na primeira, se ressalta a acepção anglo-saxônica, onde o termo é considerado uma entidade genérica da qual podem ser extraídas pequenas partes ou um conjunto de dados específicos que tenham um significado especial a um determinado indivíduo. Já na visão subjetiva, tudo teoricamente poderia ser considerado informação, já que o que confere a algo tal "poder" é o indivíduo. Portanto, nessa concepção o objeto em si não é considerado informação até que um sujeito o enxergue como tal, perspectiva que pode gerar dubiedades em relação ao "valor" da informação. 
Além de falar das principais propriedades da informação Frochot (2003) também discute sua relação com o documento. Seria deveras simplista, segundo o autor, responder apenas que o documento é onde estão gravadas as informações. No entanto essa abordagem objetiva nos permite identificar duas pistas para este "enigma": a relação entre documento e informação e o fato do documento ser um suporte de informação. O documento funciona como um "apoio" à informação, podendo ser tomado tanto considerando sua "naturalidade" como um registro de informação (a exemplo do livro), ou enxergando seu valor atribuído, a exemplo de um objeto banal como um bilhete que adquire importância testemunhal. Já a informação, em si mesma, tem um interesse limitado e, estruturada em um registro, ganha maior potencialidade, servindo como um "trampolim para o conhecimento", pois ajuda a estabelecer, reconstruir e até enriquecer o saber (FROCHOT 2003).

Le Coadic (2004), em sua difundida obra Ciência da Informação, antes de enunciar sua concepção de informação, retoma as origens físicas, relacionadas à Teoria do Sinal, segundo a qual a informação funciona como uma medida de organização de um sistema, e as concepções relacionadas à cognição e comunicação humana, acepções distintas assumidas pelo termo que lhe conferem uma feição de "noção camaleônica". Contudo, na tentativa de demonstrar maior clareza no sentido do termo, o autor distingue informação de dado, conhecimento e comunicação, termos que, segundo ele, são facilmente confundidos com informação.

No caso do termo "dado", podemos facilmente associá-lo ao domínio da Informática, já que significa "uma representação convencional, codificada, de uma informação em uma forma que permita submetê-la a processamento eletrônico" (LE COADIC, p.8, 2004). Já o termo "conhecimento", é o ato pelo qual apreendemos um objeto, ou seja, a capacidade de formar alguma ideia ou saber relacionado à informação. Quando constatamos um estado anômalo, ao obtermos a informação poderíamos "corrigir tal anomalia", o que resultaria um "novo estado" de conhecimento. E quanto à "comunicação", o autor ressalta o equívoco de utilizar o conceito de informação no processo da comunicação humana, dizendo que a comunicação na verdade é um processo intermediário que permite a troca de informações entre as pessoas, ou seja, enquanto a comunicação é um ato, processo e mecanismo, a informação é um produto, substância e matéria (LE COADIC, p.11, 2004). 
A partir de tais reflexões, Le Coadic (2004) define sinteticamente informação como um conhecimento inscrito em um suporte. Tal inscrição é feita por meio de um sistema de signos, em que o signo, elemento básico da linguagem, associa um significante a um significado, conferindo à informação, portanto, um elemento de sentido. Tal sentido por sua vez, é transmitido para um ser "consciente".

Abaixo a síntese das noções do termo informação dos autores francófonos:

\begin{tabular}{|c|c|c|}
\hline Autores francófonos & Datas & Síntese dos conceitos de Informação \\
\hline Michel & 2000 & $\begin{array}{l}\text { Expressão Informação-documento } \\
\text { (dois lados de um mesmo conceito): } \\
\text { Em uma face o conteúdo, o sentido e } \\
\text { a inteligência (informação) e do } \\
\text { outro aquilo que comunica, transfere, } \\
\text { e é obtido através de um suporte } \\
\text { (documento). }\end{array}$ \\
\hline Frochot & 2003 & $\begin{array}{l}\text { Visão objetiva- Conjunto de dados } \\
\text { específicos que tenham um } \\
\text { significado especial a um } \\
\text { determinado indivíduo. } \\
\text { Visão Subjetiva- Qualquer objeto em } \\
\text { que um sujeito "enxergue" seu valor } \\
\text { informativo. } \\
\text { Relação documento/informação } \\
\text { (valor real X valor atribuído) }\end{array}$ \\
\hline Le Coadic & 2004 & $\begin{array}{l}\text { Informação como um conhecimento } \\
\text { inscrito em um suporte. }\end{array}$ \\
\hline
\end{tabular}

Quadro 5- Síntese dos autores francófonos para o termo informação

\subsubsection{Autores espanhóis}

Currás (1986) retoma as origens do termo informação, relacionando-as a "dar forma a algo" para ratificar sua visão sobre o termo. Para ela, a informação seria um elemento vital de nossas vidas que poderia se manifestar basicamente de dois modos: como fenômeno, ou seja, aquilo que é produzido ao nosso redor independentemente de 
nós, e que captamos de forma consciente ou inconsciente; ou um processo, elaborado por nós utilizando, por exemplo, os documentos para sua representação. A autora salienta que diferentemente da escola anglo-saxã em que a informação representa o "todo" e a Documentação fica responsável pela "parte" que prepara os documentos para obterem os dados convertidos em informação, na escola europeia, principalmente espanhola e francesa, o documento é o "todo" e a informação é que representa a "parte".

Lund (2009) destaca outro autor que retoma estudos mais remotos do termo, Martinez Comeche (2000) que, ao resgatar Stonier, fala da entropia negativa da informação, ou seja, sua capacidade quase ilimitada de organizar um sistema, permitindo a estruturação e a consolidação de um conhecimento na memória. Ressalta a relação da informação com a Comunicação, dizendo que a ideia do que é informativo está relacionada aos conhecimentos prévios de um receptor, ou seja, a "natureza" da informação é transitória, já que só assume seu valor em contato com o indivíduo que a significa em seu contexto.

Imersos num contexto de rápida mudança tecnológica, conjuntural e paradigmática, conceitos como documento e informação, não são nem estáveis nem estáticos. Segundo Pérez Torero (2000) tanto a informação como o documento transformaram-se em elementos simultâneos e transversais de uma realidade cada vez mais dinâmica. Para ele, tal fenômeno é perceptível nas relações estabelecidas entre informação, documento e linguagem. Os conteúdos documentais, por exemplo, interagem com os diferentes sistemas de signos estabelecendo relações sincréticas e simultâneas, podendo também podem estabelecer relações hierárquicas entre eles. Contudo, geralmente também são marcados por instabilidade e variabilidade, pois o conteúdo do documento, a informação, derivaria da conjunção e da complementaridade de diversos tipos de signos.

Moreiro González (2005), ao falar de informação, retoma a importância da intervenção da tecnologia nos processos informativos, já que para ele a ideia de se informar está associada à combinação de um esforço mental com um processamento tecnológico. Da evolução da escrita à imprensa, depois as posteriores tecnologias e canais empregados na representação material das informações, muitos fatores que influenciaram a própria concepção documental, hoje são revistos sob a ótica digital. A ideia de suporte antes associada ao documento, ganha outra perspectiva no contexto 
digital caracterizado pelo acesso irrestrito, facilidade de manejo e atualização de documento, recuperação interativa da informação e a possibilidade de entrelaçamento interno e externo dos documentos eletrônicos por utilizarem as estruturas lógicas hipertextuais.

Mesmo com tantas vantagens, Moreiro Gonzaléz (2005) aponta como problemas a progressiva e ilimitada quantidade de documentos e o consequente entrave de recuperação seletiva; a redução da vida informativa média das mensagens, resultado da volátil dinâmica de interatividade comunicacional; a dispersão de publicações sobre temas específicos; o crescimento de documentos auto-editados, gerando mais problemas na indexação e recuperação de conteúdos. Ainda com a nítida proximidade entre os termos documento e informação, Moreiro destaca que a finalidade dos documentos seria comunicar a informação, ou seja, o processo documentário só se completaria quando a mensagem fosse efetivamente disponibilizada, sendo que tal ação só se concretizaria por completo quando adquirisse significado pela comunicação interpessoal. Tal afirmação denota sua visão voltada à informação e comunicação como conceitos em contínuo diálogo.

Já García Gutiérrez (2002), acredita que a ideia de uma informação registrada seria um paradoxo, já que para ele informação é sinônimo de fluxo, logo, não poderia estar "contida" e fixada em um suporte. Influenciado pela Teoria da Recepção e estudos da vertente cognitiva, García Gutiérrez (2002) afirma que a informação é um processo que corrobora a construção de nosso conhecimento, pois como elemento metacognitivo modifica nossas estruturas mentais:

Así la información airea el conocimiento (el registrado y el viviente) en un proceso de oxigenación pública (y de limpieza dialéctica) del exoteros organizado al interaccionar (para su enriquecimiento mutuo) con el individual endoteros (el conocimiento vivo).Por tanto, la información (que no es el oxígeno sino la oxigenación) no es confinable, ni archivable, ni registrable (GARCÍA GUTIÉRREZ, p.58, 2002).

Considerando, portanto, a informação como um continum, García Gutiérrez (2002) usa a metáfora de um "espiral ilimitada" para falar de outro aspecto desse "fluxo", seu poder de influenciar e ser influenciado pelo sujeito, ou seja, a informação seria um microuniverso que nos manipula, mas que nós também manipulamos, o que lhe conferiria um caráter dinâmico, fruto de uma relação intersubjetiva. 
Abaixo a síntese das noções dos autores espanhóis:

\begin{tabular}{|c|c|c|}
\hline Autores espanhóis & Datas & Síntese dos conceitos \\
\hline Currás & 1986 & $\begin{array}{l}\text { Informação como fenômeno } \\
\text { Informação como processo } \\
\text { (o documento é o todo e a } \\
\text { informação é que representa a parte). }\end{array}$ \\
\hline Martinez Comeche & 2000 & $\begin{array}{l}\text { A ideia do que é informativo está } \\
\text { relacionada aos conhecimentos } \\
\text { prévios de um receptor. }\end{array}$ \\
\hline Pérez Torero & 2000 & $\begin{array}{l}\text { Relação documento/informação } \\
\text { Informação como conteúdo do } \\
\text { documento, derivada da } \\
\text { conjunção e da } \\
\text { complementaridade de diversos } \\
\text { tipos de signos. }\end{array}$ \\
\hline Moreiro González & 2005 & $\begin{array}{l}\text { A ideia de se informar está } \\
\text { associada à combinação de um } \\
\text { esforço mental com um } \\
\text { processamento tecnológico. } \\
\text { Relação documento/informação } \\
\text { (finalidade dos documentos: } \\
\text { comunicar a informação). }\end{array}$ \\
\hline García Gutierrez & 2002 & $\begin{array}{l}\text { A informação é um processo que } \\
\text { corrobora a construção de nosso } \\
\text { conhecimento, pois como } \\
\text { elemento metacognitivo modifica } \\
\text { nossas estruturas mentais. }\end{array}$ \\
\hline
\end{tabular}

Quadro 6- Síntese dos autores espanhóis para o termo informação 


\subsection{Noções dos termos “documento" e "informação" para os autores nacionais}

No intuito de traçar um breve panorama do que tem sido pesquisado acerca das noções de "documento" e "informação" serão retomados aqui os estudos mais recentes sobre essa temática no Brasil. O objetivo dessa revisão é observar tanto o desenvolvimento recente da pesquisa nacional sobre os termos, como verificar suas principais tendências. O critério para seleção dos autores foi cronológico, considerando os últimos 10 anos, e temático, pesquisando trabalhos - artigos de periódico e tesesque tratassem sobre o tema em questão e trouxessem a definição dos termos. Para isso, foram pesquisados periódicos da área no Portal Capes e teses da Base de dados Digital das universidades UNESP, USP e UNICAMP.

\subsubsection{A noção de "documento"}

Mesmo com a disseminação dos estudos da Ciência da Informação focando em seu suposto objeto - a informação, presente também em outros domínios -, tem aumentado nos últimos anos as pesquisas acerca do "documento". Uma hipótese para tal tendência seria a percepção de que ambos os conceitos estejam mais próximos do que se imagina e com isso são traçados outros tipos de relações e percepções a respeito da Ciência da Informação. Nesta breve revisão serão apresentadas basicamente duas linhas de definições: uma abordagem mais genérica e de caráter mais objetivo; e outra que relaciona mais intrinsecamente os termos "documento" e "informação".

Em relação à primeira abordagem, temos Miranda (2003) que acrescenta uma perspectiva mais cartesiana à análise do termo. O autor define documento como uma célula estrutural do conhecimento registrado, que segundo os princípios cartesianos pode ser decomposta nas seguintes partes: tipo (formas que determinam os modos de uso e produção); conteúdo (parte substantiva); formato (modo de concepção e exposição do conteúdo) e suporte (parte visível e manipulável). Miranda (2003) ainda faz a ressalva de que mesmo com a percepção dessas partes é necessário considerar a interrelação entre elas para qualquer alteração, afirmando que ela é a base da arquitetura do documento que desenvolve as práticas da comunicação.

$\mathrm{Na}$ outra abordagem podemos destacar cinco autores: Murguia e Grigoleto (2009); Rabello (2009), Ortega (2009b) e Marcondes (2010). Murguia e Grigoleto (2009) tratam da importância do documento e da informação sob o aspecto da 
constituição do patrimônio. Dessa forma, afirmam que qualquer coisa poderia ter um valor informativo, mas que tal "atribuição" de valor se constituiria por meio do documento. Tal visão resgata os preceitos de Frohmann (2006) ao considerar que a materialização da informação ocorre por meio da documentação, identificando assim os aspectos institucionais, tecnológicos, políticos e culturais dessa informação.

Rabello (2009), num estudo histórico-conceitual do documento, resgata tanto as contribuições de disciplinas como História, Diplomática e Documentação consideradas bases da acepção do termo na Ciência da Informação -, como retoma as acepções de informação apresentadas por Capurro (2007), considerando que uma das variações do conceito - a informação registrada - pressupõe a noção de documento. Diante disso, apresenta as três principais abordagens que se relacionam a essa concepção de informação/registro, o que em seguida lhe auxilia para compreender o conceito de documento.

As principais abordagens, relacionadas aos paradigmas de Capurro (2007) são: a objetiva, focalizada no processo comunicativo (mensagem), a subjetiva, que enfatiza a interpretação do indivíduo isolado; e a objetiva/subjetiva social que materializada contextualiza um sistema de informação documentário com valor institucional e social. Diante desse quadro conceitual, Rabello (2009) chega a uma noção do termo documento:

[...] nenhum documento é propriamente objetivo, ou seja, nenhum objeto/suporte nasce com status de documento, pois tal aspecto valorativo somente se constituirá a posteriori. Nesse contexto, o documento será o produto de um processo de objetivação (valoração) num ato interpretativo e de atribuição de significados e sentidos, sob a influência dos aspectos subjetivos condicionados" pelo contexto social e cultural com os quais os sujeitos necessariamente se relacionam. Considerando essa especificidade, o documento é, portanto, o fruto de uma ação interpretativa (subjetiva) de um sujeito que vive em sociedade e que recebe sua influência passiva e dativamente a um só tempo (RABELLO, p.11, 2009).

Ortega (2009b) também resgata as raízes históricas do documento, retomando as principais linhas de estudo - corrente francesa, espanhola e americana - além de trazer os fundamentos da Documentação, que segundo a autora corroboram a compreensão da Ciência da Informação, já que tanto na noção de documento como nas práticas documentárias já existia o germe da noção de informação. Nessa perspectiva, a autora enxerga a noção de documento atrelada à condição de informatividade, perspectiva que ressalta o valor pragmático do objeto informacional, revelando seu aspecto simbólico e social nas situações concretas de uso, e produção do conhecimento. 
Além disso, a autora ainda retoma Meyriat (1981) dizendo que o documento não é um dado, mas o produto de uma "vontade de informar", já que é uso que se faz dele que lhe permite ser encarado como documento. Logo, o papel do usuário é fundamental, pois é ele que atribui tal valor, que pode tanto voltar-se para um objeto intencionalmente pensado para ser um documento, como para outro que não foi originalmente produzido para $\operatorname{tal}^{17}$.

Para finalizar temos Marcondes (2010), que antes de definir documento ressalta duas importantes características: uma de ordem primária, o caráter instrumental, e outra secundária, a função sócio-simbólica. A primeira característica está ligada à função informativa dos documentos, que viabilizam de forma mediada a "transferência" da informação a fim de modificar o quadro mental dos possíveis receptores. A outra, segundo o autor é um desdobramento da primeira, já que se dá em contextos sociais específicos, influenciados pelas relações sociais e o uso efetivo do documento.

Diante disso o autor lembra que a chave para os processos informativos é dada pela linguagem, em especial a Semiótica. A partir dela, traça a definição de documento como: "documentos são objetos especiais inseridos em relações sígnicas, por serem artefatos, por serem artificiais, por carregarem uma intencionalidade" (MARCONDES, p.13, 2010). O autor assim destaca o papel da intencionalidade do produtor/criador como essencial para caracterizar os documentos, já que “o significado não está no documento em si, mas no documento dentro de contextos específicos, sendo isso que permite os documentos funcionarem como mecanismos de articulação, coordenação e cooperação social” (MARCONDES, p.12, 2010).

Abaixo, um quadro síntese das definições acima:

\begin{tabular}{|l|l|}
\hline Autor/Ano & Definição \\
\hline MIRANDA (2003) & $\begin{array}{l}\text { Célula estrutural do conhecimento } \\
\text { registrado, que segundo os princípios } \\
\text { cartesianos pode ser decomposta nas } \\
\text { seguintes partes: tipo; conteúdo; formato e } \\
\text { suporte. }\end{array}$ \\
\hline
\end{tabular}

\footnotetext{
${ }^{17}$ Além disso, a atribuição do que é documento, relacionado à função informativa, também é algo que se modifica com o tempo (ORTEGA; LARA, 2010).
} 


\begin{tabular}{|l|l|}
\hline MURGUIA (2009) & $\begin{array}{l}\text { Qualquer coisa pode ter um valor } \\
\text { informativo, e apenas os documentos } \\
\text { teriam como atribuir a tais elementos um } \\
\text { valor científico e testemunhal. }\end{array}$ \\
\hline RABELLO (2009) & $\begin{array}{l}\text { Produto de um processo de objetivação } \\
\text { (valoração) num ato interpretativo e de } \\
\text { atribuição de significados e sentidos, sob a } \\
\text { influência dos aspectos subjetivos } \\
\text { condicionados pelo contexto social e } \\
\text { cultural com os quais os sujeitos } \\
\text { necessariamente se relacionam. }\end{array}$ \\
\hline ORTEGA (2009) & $\begin{array}{l}\text { O documento não é um dado, mas o } \\
\text { produto de uma “vontade de informar", já } \\
\text { que é uso que se faz dele que lhe permite } \\
\text { ser encarado como documento. }\end{array}$ \\
\hline MARCONDES (2010) & $\begin{array}{l}\text { Documentos são objetos especiais } \\
\text { inseridos em relações sígnicas, por serem } \\
\text { artefatos, por serem artificiais, por } \\
\text { carregarem uma intencionalidade" }\end{array}$ \\
\hline
\end{tabular}

Quadro 7 - Síntese dos autores brasileiros para o termo documento

\subsubsection{A noção do termo "informação"}

Considerando a polissemia e a diversidade de uso do termo informação no contexto atual, fica difícil delimitar um grupo de autores para representar tal noção no Brasil. Todavia, fazendo o recorte temporal de aproximadamente uma década, e buscando autores preocupados em entender tal conceito à luz da Ciência da Informação, foram selecionadas três categorias de definições: uma de aspecto mais generalista, outra essencialmente fundamentada na relação conhecimento e informação, e a última mais voltada ao aspecto pragmático da noção do termo. 
Numa visão mais abrangente do termo, temos González de Gomes (2002) que assim como Capurro e Hjorland (2007), apresenta uma revisão de literatura do termo, ressaltando três principais linhas de estudo: a cognitiva, que relaciona informação e conhecimento; a textual, que encara a informação como linguagem e produção de sentido; e a social, que considera a informação como um artefato cultural produto das práticas sociais de uma comunidade. Assim, para autora, mesmo com a "flutuação de significado" do termo informação, decorrente das dificuldades de constituição da área da Ciência da Informação, considera a noção contemporânea do termo associada ao conceito de representação ${ }^{18}$. Tal noção traz em seu bojo a capacidade de introduzir a informação na esfera do humano tanto num contexto do conhecimento como no da linguagem.

$\mathrm{Na}$ definição que aproxima informação e conhecimento destacamos dois autores, Miranda (2003) e Barreto (2002). O primeiro lembra o valor da informação como matéria-prima de todas as áreas do conhecimento, ressaltando que para a Ciência da Informação privilegia-se a visão de informação como conhecimento registrado, relacionando assim a noção de documento na concepção popperiana ${ }^{19}$. Barreto (2002) por sua vez, considera a informação como sendo uma estrutura simbolicamente significante que tem a competência de gerar o conhecimento no indivíduo, atuando assim como um instrumento modificador da consciência humana, "sintonizando o homem com a memória de seu passado e com as perspectivas de seu futuro" (BARRETO, p.49, 2002).

Já Tálamo e Smit (2007) ressaltam que a noção de informação não deve ser encarada apenas como ideia intangível, sinônimo de conhecimento, mas ser visualizada sob o aspecto do tangível, ou seja, considerando seu papel em representar diferentes formatos de organização do conhecimento. Assim temos:

\footnotetext{
18 "O conceito de representação remete a algo (representado) que tem um modo de ser que lhe é próprio, mas que, não sendo acessível no modo de presença, por estar ausente aqui e agora, se re-apresenta, num modo diferente de manifestação (a representação)"( GONZÁLEZ DE GOMES, p.27, 2002).

${ }^{19}$ A Teoria do Conhecimento Objetivo de Karl Popper é dividida em três mundos: o mundo 1 constituído pelos conhecimentos relacionados ao mundo físico ("o mundo dos estados materiais"); o mundo 2 compreende os conhecimentos relativos ao mundo metafísico (estados mentais e da subjetividade); e mundo 3 , é do conhecimento objetivo("o mundo dos inteligíveis") Assim, e os mundos 1 e 2 problematizam os fenômenos físicos e metafísicos ou, o mundo 3 tem a ver com o conhecimento registrado, com as suas teorias, proposições e demais entidades linguísticas que entram na codificação e registro do conhecimento.(POPPER, 1975, apud MIRANDA, 2003).
} 
[...] a informação não se apresenta como objeto, mas como um ponto de vista adotado para analisar os processos e objetos do mundo [...] Neste quadro o objeto da Ciência da Informação não é mais o intangível - o conhecimento - não é mais o suporte ou o local, mas algo tangível - a informação representada em diferentes formatos de organização (TÁLAMO; SMIT, p.23, 2007).

Dessa forma, o conhecimento seria uma elaboração cognitiva individual, mas para ser assimilado precisaria de uma representação, que permitiria o acesso, uso e sua socialização, a informação (ORTEGA, 2009b). Tálamo (2005, citado por ORTEGA, 2009b) sintetiza tal distinção entre conhecimento e informação dizendo que a informação seria o fluxo e o conhecimento o estoque. Enquanto o estoque seria passivo, o fluxo teria o papel de ativá-lo por meio dos variados produtos informacionais.

Nessa perspectiva mais pragmática encontramos também outros autores. Silva (2002), por exemplo, considera a informação como o conjunto estruturado de representações codificadas, que podem ser socialmente contextualizadas, ou seja, permitem o registro em qualquer suporte material, podendo assim ser comunicadas e difundidas no tempo e espaço. Robredo (p.8, 2005) toma a informação como uma “energia de realidade própria" associada a um sistema de organização, estando assim suscetível de ser registrada, codificada, duplicada, reproduzida, armazenada, conservada, medida, qualificada, organizada, processada, recuperada e transmitida em diferentes níveis.

Araújo (2002) retoma a perspectiva que associa a informação com o conhecimento, mas acrescenta à sua definição aspectos das práticas informacionais. Primeiramente afirma que o conceito de informação teria dois sentidos complementares: um como processo de atribuição de sentido e outro como processo de representação. $\mathrm{O}$ primeiro, em termos de práticas informacionais, estaria relacionado às ações de recepção/seleção das informações recebidas; enquanto o segundo, relacionado às ações de codificação, emissão, decodificação/uso da informação, estaria voltado à geração e transferência da informação. Como noções complementares a informação poderia ser encarada como uma prática social que envolve ações de atribuição e comunicação de sentido.

Outro trabalho interessante de se destacar é o Conceito de informação na Ciência da Informação de Araújo (2010). A partir do trabalho de Capurro, que realizou uma densa revisão de literatura sobre o termo, Araújo verifica em seu artigo como os 
paradigmas de Capurro se manifestam nas subáreas da Ciência da Informação denominadas nos grupos de Trabalho da ANCIB (Associação Nacional de Pesquisa em Ciência da Informação). É interessante observar que mesmo apresentando as nuances de cada paradigma - a dimensão material do aspecto físico; a clássica medida de alteração do estado anômalo do conhecimento do aspecto cognitivo; e a noção de informação como um elemento construído contextualmente a partir de relações interpessoais, no caso do aspecto social - associados aos grupos temáticos ${ }^{20}$, nota-se uma complementaridade entre os aspectos, o que evidencia para o autor que para a compreensão do conceito seria necessário enxergar os paradigmas inter-relacionados.

Abaixo, um quadro ilustrativo de síntese das definições acima:

\begin{tabular}{|l|l|}
\hline Autor/Ano & Definição \\
\hline GONZÁLEZ DE GOMES (2002) & $\begin{array}{l}\text { Revisão histórica (aspecto cognitivo, } \\
\text { textual, social); } \\
\text { Informação como sinônimo de } \\
\text { representação. }\end{array}$ \\
\hline BARRETO (2002) & $\begin{array}{l}\text { Estrutura simbolicamente significante que } \\
\text { tem a competência de gerar o } \\
\text { conhecimento no indivíduo. }\end{array}$ \\
\hline SILVA (2002) & $\begin{array}{l}\text { Informação como o conjunto estruturado } \\
\text { de representações codificadas, que podem } \\
\text { ser socialmente contextualizadas. }\end{array}$ \\
\hline ARAÚJO (2002) & $\begin{array}{l}\text { O conceito de informação teria dois } \\
\text { sentidos complementares: um como } \\
\text { processo de atribuição de sentido e outro }\end{array}$ \\
\hline
\end{tabular}

${ }^{20}$ Os grupos temáticos da Ancib são: GT1 estudos históricos e epistemológicos da informação; GT2 Organização e apresentação do conhecimento; GT3 Mediação, circulação, e apropriação da informação; GT4 gestão da informação e do conhecimento nas organizações; GT5 Política e economia da informação; Gt6 Informação, educação e trabalho; GT7 Produção e comunicação da informação em C\&T; Gt8 Informação e tecnologia; GT9 Museu, patrimônio e informação e GT10 Informação e memória.No caso do artigo de Araújo, foram excluídos da análise os grupos GT1, GT6, GT8, GT9 e GT10 (ARAÚJO, 2010). 


\begin{tabular}{|c|c|}
\hline & como processo de representação. \\
\hline MIRANDA (2003) & $\begin{array}{l}\text { Conhecimento registrado, relacionado } \\
\text { assim a noção de documento na } \\
\text { concepção popperiana. }\end{array}$ \\
\hline ROBREDO (2005) & $\begin{array}{l}\text { Energia de realidade própria" associada a } \\
\text { um sistema de organização. }\end{array}$ \\
\hline TÁLAMO (2005) & $\begin{array}{l}\text { Informação é fluxo, que tem o papel de } \\
\text { ativar o estoque (conhecimento). }\end{array}$ \\
\hline SMIT, TÁLAMO (2007) & $\begin{array}{l}\text { Sob o aspecto do tangível, deve ser } \\
\text { considerado seu papel em representar } \\
\text { diferentes formatos de organização do } \\
\text { conhecimento. }\end{array}$ \\
\hline ARAÚJO (2010) & $\begin{array}{l}\text { Informação resultado da inter-relação dos } \\
\text { aspectos físicos, cognitivos e sociais. }\end{array}$ \\
\hline
\end{tabular}

Quadro 8 - Síntese dos autores brasileiros para o termo informação

O objetivo até aqui foi perpassar pelas principais noções dos termos documento e informação. Tendo em mente este panorama histórico-conceitual, somado a outras acepções que serão trazidas no capítulo posterior encetadas pela análise terminológica, serão observadas as similitudes e distinções entre os termos "documento" e “informação" no âmbito da Ciência da Informação. 


\section{Capítulo - Noções dos termos ‘documento’ e ‘informação': análise terminológica}

\subsection{Descrição metodológica}

A pesquisa propõe-se a identificar as noções dos termos "documento" e "informação" a partir de uma abordagem terminológica para análise e comparação das noções. A revisão de literatura feita no capítulo anterior permitiu traçar uma visão panorâmica das principais acepções dos termos, no âmbito do recorte cronológico e da cobertura temática elegida. Já a segunda etapa, a análise terminológica, será feita nesse capítulo, com a ressalva de que a perspectiva terminológica escolhida foi a contemporânea, mais precisamente a linha da Teoria Comunicativa, em que se enfatiza o aspecto pragmático e social dos termos.

Considerando que a Terminologia tem instrumental para identificar conceitos, termos e organizá-los de forma sistêmica em domínios, optou-se por utilizá-la nessa etapa do trabalho a fim de discutir mais aprofundadamente as noções de "documento" e “informação". Como qualquer outro trabalho de natureza terminológica, é necessária a adoção de alguns critérios que delimitem o corpus de trabalho. Dessa forma, o procedimento metodológico de análise terminológica ocorreu em quatro fases: levantamento bibliográfico para a construção do corpus; leitura e coleta de termos; análise dos termos; e síntese das noções.

A primeira fase, o levantamento bibliográfico, como já foi mencionada na Metodologia, foi feita a seleção do corpus de apoio e de trabalho. Na segunda fase, foi feita a coleta e o registro dos termos em fichas terminográficas, inspiradas nas sugestões de Barros (2004), fichas de trabalho e síntese, e Cabré (1993), fichas e terminológicas. Dessa forma, utilizamos as simplificações das fichas de coleta de termos, de análise e síntese. Abaixo uma réplica dos modelos utilizados ${ }^{21}$ :

\footnotetext{
${ }^{21}$ As definições de cada entrada da ficha foram retiradas do glossário terminológico do Pavel (2011). Os campos mostrados como exemplos foram retirados dos modelos de fichas de Barros (2004) e Cabré (1999).
} 


\begin{tabular}{|c|c|c|}
\hline Termo & Contexto & Referência \\
\hline $\begin{array}{l}\text { "Palavra, grupo de } \\
\text { palavras, que } \\
\text { designam uma } \\
\text { noção de uma área } \\
\text { específica". }\end{array}$ & $\begin{array}{l}\text { "Parte de um texto } \\
\text { ou enunciado, em } \\
\text { que está inclusa } \\
\text { uma unidade } \\
\text { lexical, com a } \\
\text { função de } \\
\text { contribuir para a } \\
\text { determinação do } \\
\text { seu significado". }\end{array}$ & $\begin{array}{c}\text { "Pessoa, } \\
\text { organização ou } \\
\text { obra de referência } \\
\text { que fornece } \\
\text { informação ou } \\
\text { documentos que } \\
\text { servem para atestar } \\
\text { o uso de um } \\
\text { termo". }\end{array}$ \\
\hline
\end{tabular}

Quadro 9- Exemplo de campos de uma ficha de coleta

\begin{tabular}{|c|c|c|c|c|c|}
\hline Termo & Contexto & Tradução & Caract.1 & Caract. 2 & Caract. 3 \\
\hline $\begin{array}{l}\text { "Documento" } \\
\text { ou } \\
\text { "Informação" }\end{array}$ & $\begin{array}{l}\text { "Prova textual } \\
\text { que fornece } \\
\text { informação } \\
\text { sobre os traços } \\
\text { semânticos de } \\
\text { uma noção, } \\
\text { que é } \\
\text { subdividida } \\
\text { em } \\
\text { características } \\
\text { semânticas". }\end{array}$ & & $\begin{array}{c}\text { "Unidade de } \\
\text { significado, } \\
\text { ou } \\
\text { propriedade } \\
\text { mínima, } \\
\text { usada para } \\
\text { descrever um } \\
\text { conceito ou } \\
\text { noção. } \\
\text { Também } \\
\text { chamada de } \\
\text { traço } \\
\text { semântico". }\end{array}$ & Idem & Idem \\
\hline
\end{tabular}

Quadro 10 - Exemplo de campos de uma ficha de análise

\begin{tabular}{|c|c|c|c|c|c|}
\hline Termo & Contexto & Tradução & Caract.1 & Caract.2 & Caract.3 \\
\hline "Documento" & & & & & \\
ou \\
"Informação"
\end{tabular}

Síntese- "Redação de uma definição de acordo com os princípios terminológicos estabelecidos. Nela há uma correspondência entre os traços semânticos de diversos contextos ou definições, que servem para demonstrar que todos os dados consignados em uma ficha terminológica se referem a uma única noção". 
$\mathrm{Na}$ terceira fase, foram selecionados doze contextos, sendo seis para o termo "documento" e seis para o termo "informação", cobrindo os últimos dez anos. Dos seis contextos, foram reservados dois para cada um dos idiomas dos autores, ou seja, dois artigos em francês, dois em espanhol e dois em inglês. As fichas de análise, conforme vimos acima, contêm os seguintes elementos de entrada: termo, referência, contexto, tradução e trechos do contexto subdividido em três características semânticas: perspectiva objetiva, perspectiva subjetiva e perspectiva social.

Quanto à escolha dos autores, para compor a análise terminológica, podemos apontar quatro critérios: primeiro, estarem presentes nas referências e sugestões bibliográficas de Lund (2009), Capurro (2007) e Ortega (2004, 2008, 2009abc, 2010); segundo, serem autores que tenham sua produção em espanhol, inglês ou francês; terceiro, que seus textos tenham sido publicados nos últimos 10 anos; e o quarto, e talvez mais salutar, que a visão apresentada sobre a noção de documento e informação não se limitasse apenas a uma perspectiva.

Os textos selecionados para análise terminológica do termo documento foram: Document theory (Lund, 2009), What's in a Name? Contextualizing the Document Concept (Francke, 2005), El documento: entre La teoría y la renovación (Rodrígues Bravo, 2002), Complexidade e documento: a hibridação das mediações nas áreas em ruptura (Couzinet, 2009), Para una teoría informativa del documento: extensión y aplicabilidad del concepto (Reig Cruãnes, 2005), Document: forme, signe et medium, le reformulations de numériques (Pédauque, 2003); e para o termo informação: La science de l'information ou le pois de l'histoire (Fondin, 2005), Redes que a razão desconhece: laboratórios, bibliotecas, coleções (Latour, 2008), Theorizing Information for Information Science (Cornelius, 2002), El concepto de Documentación en la doctrina española (Ros García, 2000), The conduit metaphor and the nature and politics of information studies (Day, 2000) e El documento: entre La teoría y la renovación (Rodrígues Bravo, 2002).

É importante ressaltar aqui o que se entende por "perspectiva". Como os contextos analisados trazem características semânticas interdependentes, ou seja, em que os traços estão muito imbricados, fica difícil delimitá-los restringindo a extensão de seus traços. A opção escolhida para tratá-los de forma mais relativa e dialógica foi encará-los como "ênfases" diferentes, mas complementares, de uma mesma noção. 
Assim, quando se fala, por exemplo, da perspectiva física destaca-se a materialidade; já na nuance subjetiva, valoriza-se o papel do sujeito na atribuição do que pode ou não ser um documento; e na ênfase social, expande-se a visão subjetiva, considerando não só o sujeito isolado em sua produção/apreensão de sentido, mas o contexto e a situação espaço-temporal em que está envolvido. Neste último sentido, as referências podem ser sociais, não individuais.

E a última fase, a síntese dos termos, foi realizada com o auxílio de quadros comparativos dos traços semânticos, como recurso para identificar as semelhanças e diferenças entre eles a fim de se chegar a uma noção dos termos ${ }^{22}$. Diante do exposto, o objetivo desse capítulo é mostrar o percurso terminológico. Começaremos mostrando as definições dos termos apresentadas pelos autores selecionados, seguidas de um quadro comparativo dos traços encontrados, e por fim apresentaremos a síntese de cada termo.

\subsection{A noção do termo "documento"}

A análise terminológica do termo "documento", de forma geral, permitiu que revisitássemos os conceitos expostos no capítulo anterior, mas também apontou uma tendência comum à noção. Mesmo considerando autores distintos, percebemos que eles apresentam mais de uma nuance da noção, podendo-se dizer até que a maioria dos autores selecionados acaba mencionando as três perspectivas: a objetiva, a subjetiva e a social. Assim, além da noção "básica" do documento como um suporte de informação, ressaltam o papel social do documento, "ativado" por um sujeito/comunidade discursiva, que lhe atribui uma função documental em determinado contexto.

O termo contexto nesse viés possui um significado diferente daquele usado na acepção terminológica - com função de prova textual ao fornecer informações sobre os traços semânticos de uma noção. Com intuito de melhor esclarecer esse outro uso dado

\footnotetext{
${ }^{22}$ É relevante relembrar aqui a escolha pelo termo "noção" ao invés de "conceito". Considerando que a composição dos traços semânticos dos termos "documento" e "informação" tem uma perspectiva mais dinâmica e inter-relacional, falar de conceito poderia sugerir uma delimitação ou até uma restrição conceitual. Já a "noção ${ }^{222}$, proveniente da tradição francesa, está ligada a uma acepção mais genérica e aberta (Rey, 1979) perspectiva mais conveniente para o tipo de análise que nos propomos a realizar neste trabalho.
} 
ao termo contexto ${ }^{23}$, trazemos a definição do Dicionário de Análise do Discurso de Charaudeau e Maingueneau(2004):

[...] o contexto pode ser enfocado de maneira estrita (contexto imediato) ou abrangente (contexto ampliado), em um eixo evidentemente gradual. No que concerne ao contexto não linguístico, o contexto estrito (ou micro) faz sobressair, por exemplo, o quadro espaço temporal e a situação social local nos quais a troca comunicativa, seus participantes (números, características, status, papéis e a relação que mantêm entre si), o tipo de atividade e as regras que a regem. Enfocado de forma abrangente, o contexto (nível macro) faz sobressair o aspecto institucional, e se apresenta, portanto, como uma série sem fim de encaixes: assim, o quadro físico último será o conjunto do mundo físico, e o quadro institucional último será o conjunto do mundo social (e poderíamos dizer o mesmo do co-texto que, pelo viés do intertexto, recobre a extensão discursiva teoricamente ilimitada).

(CHARAUDEAU E MAINGUENEAU, 2004, p.128).

Outro aspecto a ser ressaltado nos contextos analisados foi o fato de perceber que, mesmo aqueles autores que apontam certa predileção por uma perspectiva, tendem a considerar também as demais para compor a noção de documento. Diante disso, podemos chegar a uma primeira conclusão da análise, qual seja, de que as três perspectivas destacam nuances da noção de documento que devem ser visualizadas em sua inter-relação e não isoladas como propriedades distintas. Considerando tal constatação, apresentaremos na sequência a posição de cada autor analisado, a fim de melhor compreendermos os resultados da análise. Para isso, com intuito ilustrativo, foi elaborado um quadro comparativo das perspectivas, considerando trechos das fichas de análise:

\footnotetext{
${ }^{23}$ Os autores ainda trazem outras reflexões mais recentes sobre o contexto, tais como: a identificação do contexto com o conjunto de representações dos interlocutores; o fato do contexto ser construído ao mesmo tempo na e pela maneira como ele se desenvolve em diferentes situações discursivas, demonstrando uma relação dialética entre texto e contexto; o papel fundamental do contexto na enunciação e interpretação; e o reconhecimento por parte dos linguistas de que a atividade linguajeira é um fenômeno social em dois sentidos: ela é determinada pelo contexto social e é em si uma prática social (CHARAUDEAU; MAINGUENEAU, p.128, 2004).
} 


\begin{tabular}{|c|c|c|c|}
\hline Autor/ano & $\begin{array}{l}\text { Perspectiva } \\
\text { Objetiva }\end{array}$ & $\begin{array}{l}\text { Perspectiva } \\
\text { Subjetiva }\end{array}$ & Perspectiva social \\
\hline Lund (2009) & \multicolumn{3}{|c|}{$\begin{array}{l}\text { "Sugere-se que se deva ver o documento a partir de três ângulos } \\
\text { complementares: físico, social e mental". }\end{array}$} \\
\hline Francke (2005) & $\begin{array}{l}\text { "[...] documento } \\
\text { como um objeto } \\
\text { material". }\end{array}$ & & $\begin{array}{l}\text { "O documento } \\
\text { atende a uma } \\
\text { função social [...] é } \\
\text { altamente } \\
\text { dependente do } \\
\text { contexto". }\end{array}$ \\
\hline Couzinet (2009) & $\begin{array}{l}\text { "[...] é o modo no } \\
\text { qual a informação, } \\
\text { o conteúdo, ganham } \\
\text { forma no plano } \\
\text { comunicacional e é, } \\
\text { ao mesmo tempo, o } \\
\text { suporte que } \\
\text { possibilita a sua } \\
\text { circulação". }\end{array}$ & $\begin{array}{l}\text { "Não existe } \\
\text { documento a não } \\
\text { ser ligado à vontade } \\
\text { de informar". }\end{array}$ & $\begin{array}{l}\text { "[...] guardam o } \\
\text { registro de uma } \\
\text { civilização, de uma } \\
\text { arte de fazer ou de } \\
\text { um uso preciso". }\end{array}$ \\
\hline Pédauque (2003) & $\begin{array}{l}\text { "O documento } \\
\text { como forma [...] } \\
\text { objeto material ou } \\
\text { imaterial e que se } \\
\text { estuda a estrutura } \\
\text { por meio da análise, } \\
\text { utilização ou a } \\
\text { manipulação". }\end{array}$ & $\begin{array}{l}\text { "O documento } \\
\text { como signo [...] é } \\
\text { visto } \\
\text { principalmente } \\
\text { como um portador } \\
\text { de significado e } \\
\text { intencionalidade e } \\
\text { sem dúvida, e é } \\
\text { inseparável do } \\
\text { sujeito [...]". }\end{array}$ & $\begin{array}{l}\text { "O seu papel como } \\
\text { um meio: está } \\
\text { voltado à dimensão } \\
\text { da finalidade de } \\
\text { postar o status do } \\
\text { documento nas } \\
\text { relações sociais [...] } \\
\text { é inseparável do } \\
\text { sujeito no } \\
\text { contexto". }\end{array}$ \\
\hline $\begin{array}{l}\text { Reig Cruañes } \\
(2005)\end{array}$ & $\begin{array}{l}\text { "[...] o documento } \\
\text { se compõe de uma } \\
\text { mensagem } \\
\text { informativa e um } \\
\text { suporte que lhe } \\
\text { serve de veículo". }\end{array}$ & $\begin{array}{l}\text { "A noção de } \\
\text { documento pode } \\
\text { reduzir-se a uma } \\
\text { mensagem icônica } \\
\text { ou simbólica [...] } \\
\text { São meios para } \\
\text { transmitir }\end{array}$ & $\begin{array}{l}\text { "A concepção } \\
\text { informativa do } \\
\text { documento está } \\
\text { relacionada à } \\
\text { perspectiva } \\
\text { antropológica }[\ldots]\end{array}$ \\
\hline
\end{tabular}




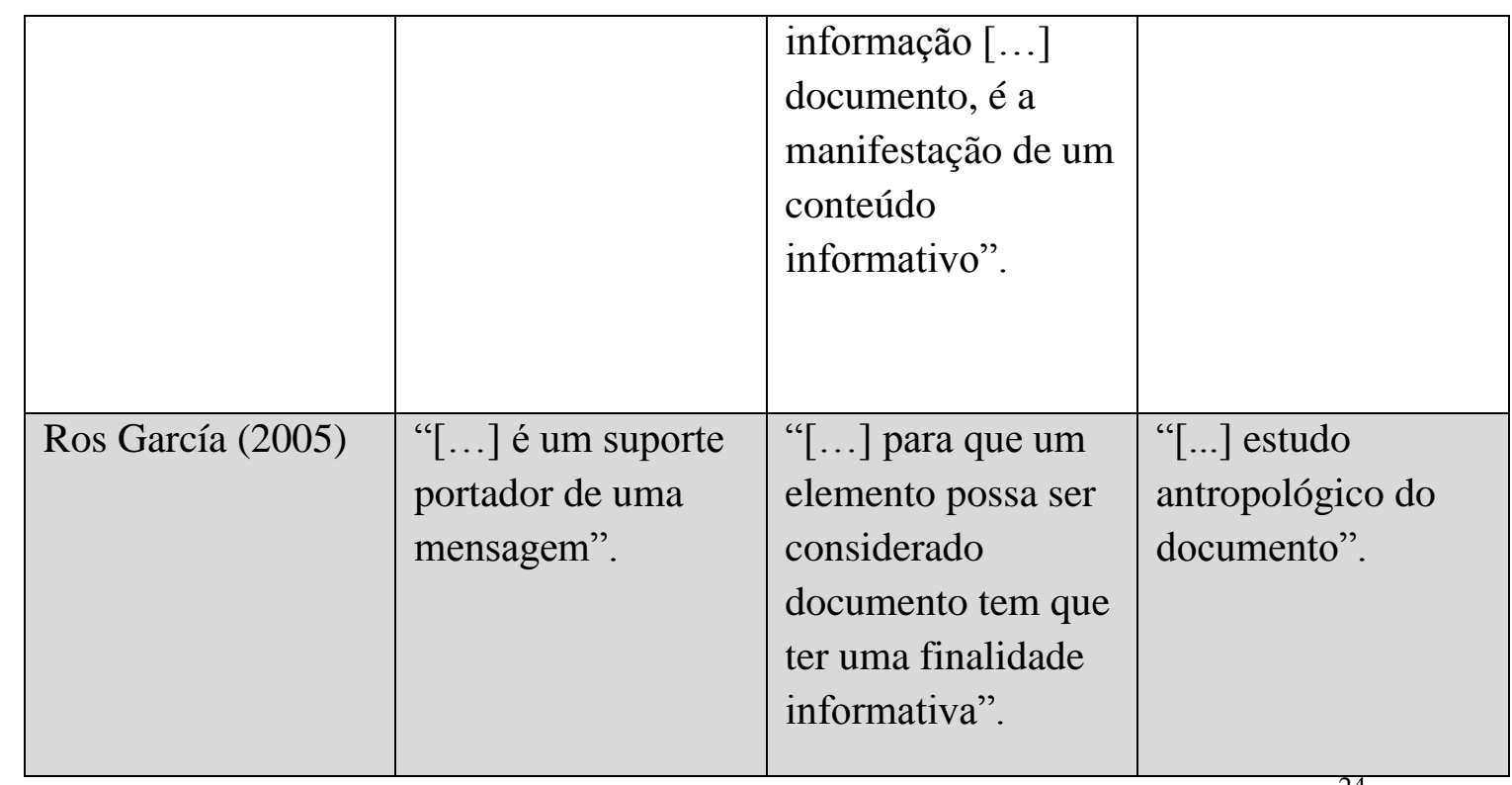

Quadro12- Quadro comparativo das perspectivas do termo documento ${ }^{24}$

Lund (2009), o primeiro autor anglo-escandinavo analisado, verifica que a noção de documento é composta de três aspectos complementares: o físico, o social e o mental, perspectivas bem difundidas na concepção de outro termo, informação. Mas sobre o documento em especial, o autor destaca que tais perspectivas mesmo complementares, não precisam ser vistas simultaneamente, ou seja, para Lund (2009) a questão central não seriam as dimensões em si, mas como elas se interagem umas com as outras. Nesse ponto, o autor ressalta o papel do contexto, elemento chave para determinar a natureza documentária.

Francke (2005) destaca a noção de documento como um "elemento estruturado" no âmbito da Biblioteconomia e Ciência da Informação (Library and Information Science). Todavia, segundo a autora, a importância do documento nessas áreas seria secundária, principalmente comparando-se com as noções de "informação" e "texto". Mas a autora lembra que tal visão está mudando, e nesse ponto ela supõe que tal alteração possa ser motivada pela percepção de que o documento atende a uma função social, concluindo que a noção de documento estaria diretamente relacionada a um contexto. Nesse viés, além da percepção da relação da estrutura do documento com sua forma material, na organização e representação do conhecimento, haveria o papel social do documento, desempenhado a fim de fornecer e preservar o conhecimento para as próximas gerações (FRANCKE, 2005).

\footnotetext{
${ }^{24}$ Optou-se por colocar aqui os trechos dos contextos traduzidos para facilitar a articulação com o texto. No entanto, as fichas terminológicas de coleta e síntese completas podem ser consultadas no Apêndice.
} 
Já na linha francesa, a noção de documento, por estar relacionada à Comunicação, como já se expressa na denominação da área - Sciences de l'Informations et Communication -, aparece predominante em duas perspectivas: a subjetiva, que privilegia o papel do emissor/receptor na elaboração da noção de documento, e a social, por considerar não só o indivíduo que produz a mensagem informativa, mas o contexto em que ele está inserido.

Couzinet (2009), por exemplo, parte da ideia do documento como objeto concreto, ou seja, "o modo no qual a informação ou conteúdo, ganha forma no plano comunicacional” (COUZINET, p.10, 2009). Para ela, o documento estaria "adormecido", não existindo per si, porém para ser "ativado", ou seja, ser conferida uma função de portador de um conteúdo informacional seria necessário "questioná-lo". Esse "questionamento" seria feito por um sujeito, responsável por "despertá-lo" ou "revelá-lo" como documento. Diante disso, Couzinet (2009) ressalta o papel do usuário/conceptor, ou seja, o "elemento propulsor" dessa "vontade de informar" (MEYRIAT, 1981 apud COUZINET, 2009).

Mesmo considerando as perspectivas objetiva e social, Couzinet (2009) privilegia a subjetiva destacando o papel do sujeito na atribuição da noção de documento, ressaltando a dimensão da finalidade/intencionalidade na criação/atribuição do que é documento. Tal concepção recupera de certa forma a visão de Meyriat (1981), já exposta na revisão de literatura do capítulo anterior, que trata do documento por intenção e atribuição ${ }^{25}$, noções que são revisitadas pelos autores franceses posteriores, como Couzinet.

Numa outra perspectiva, Pedaúque ${ }^{26}$ (2003) entende que o documento é constituído de três aspectos: a forma (como objeto material ou imaterial); o signo (como portador de sentido); e o meio (como vetor de comunicação). Para explicar cada uma

\footnotetext{
25 "O documento por intenção é aquele que serve para fixar acordos, extrair dados, o documento por atribuição é um suporte que contêm informações, mas que foi fabricado com outra intenção" (COUZINET, p.11, 2009).

${ }^{26}$ RTP Doc (Réseau, Thematique Pluridisciplinaire Documents et contenu, création, indexation et navigation) ou mais comumente conhecido com o pseudônimo de Roger T. Pedaúque, diz respeito a autoria coletiva do CNRS (Centre National de la Recherche Scientifique) na França, formado por especialistas de diversas áreas (matemáticos, linguistas, semiologistas, filósofos, e profissionais da Ciência da Informação e Informática), que estudam a Redocumentarização, com destaque para o papel do documento digital, nesse "novo" momento da Documentação.
} 
das categorias, que para ele devem ser vistas como domínios e não como dimensões exclusivas, usa uma analogia linguística.

A forma, por exemplo, estaria associada à Morfossintaxe analisando, portanto o documento como um objeto material ou imaterial, de forma a possibilitar estudar sua estrutura, com o objetivo de melhor manipulá-lo e utilizá-lo. Quanto à noção de signo estaria relacionada à Semântica, já que nesse viés, o documento seria percebido como um elemento portador de significado e dotado de uma intencionalidade, o que acarretaria perceber que o documento é indissociável do sujeito no contexto em que é construído ou reconstruído seu sentido. E o documento como meio estaria ligado à Pragmática, já que nesse aspecto se consideraria o documento como fruto das relações sociais, ou seja, produzido por um grupo social que lhe suscitaria, difundiria, armazenaria e utilizaria, destacando assim seu papel como fenômeno social (PÉDAUQUE, 2003).

Depois de perpassar pelas dimensões do documento, Pedáuque (2003) conclui que a noção de documento estaria, portanto, associada aos contratos de dimensão antropológica (legibilidade-percepção), intelectual (compreensão-assimilação) e social (sociabilidade-integração). Notamos assim, que sua posição se assemelha à de Lund, que enxerga a noção de documento associada a um conjunto de perspectivas complementares, fruto de um determinado contexto.

Na linha espanhola, talvez influenciada pela forte tradição da Documentação e dos estudos Comunicacionais, da mesma forma que a linha francesa, preponderam as perspectivas objetiva e subjetiva. A primeira possivelmente associada ao caráter material da noção de documento, como suporte; e a outra, que se relaciona não só ao inevitável processo comunicativo que se estabelece entre emissor e receptor da mensagem informativa, mas que destaca o papel da intenção comunicativa para caracterizar a finalidade informativa do documento.

Reig Cruañes (2005), mesmo considerando a perspectiva antropológica do documento, principalmente ao resgatar a afirmação de Otlet que via o documento como memória materializada da humanidade, privilegia a perspectiva objetiva. Nela o autor destaca a funcionalidade do documento como "meio de transmitir informação", ou seja, a fixação de informação sobre algum suporte material com intenção de comunicar uma mensagem. Dessa forma, estruturalmente, o documento seria composto de uma 
mensagem informativa e de um suporte que serviria de "veículo" para a mensagem, o que segundo o autor, o converteria em uma sucessão de signos. É claro que tal perspectiva acaba se associando diretamente à subjetiva, já que o autor lembra que para um signo constituir uma mensagem é preciso que haja um referente reconhecível ao emissor/ receptor, ou seja, um conjunto de signos só pode ser considerado "documento" se tiver um receptor potencial capaz de "enxergar" a informação embutida ali.

Informação e documento também se aproximam na obra El documento - entre la tradición y la renovación, de Rodríguez Bravo (2002). A autora começa o livro destacando como a difusão dos estudos informacionais e tecnológicos, após $2^{\text {a }}$ Guerra Mundial abalou "certezas" e questionou a difusão das distâncias aparentes na área, a exemplo das noções de documento e informação, que são discutidas nessa obra. Com destaque aqui para a noção de documento, Rodríguez Bravo (2002) propõe uma reflexão a partir da compreensão das diferentes concepções do termo, questionando suas aplicações e limites, além de destacar, em um capítulo, o valor da informação na constituição da natureza do documento.

Sobre a definição de documento, Rodríguez Bravo (2002) ressalta o ponto de vista da funcionalidade, destacando como essência da noção de documento sua capacidade para comunicar a informação, já que está "fixada" em um suporte. Assim, o documento seria um suporte portador de uma mensagem emitida com intenção comunicativa e potencialmente informativa para um receptor, o que para a autora se traduz em um instrumento fundamentalmente informativo. Dessa forma, o papel da intenção comunicativa do emissor seria imprescindível para se caracterizar a finalidade informativa do documento ${ }^{27}$. Notamos assim, que como Reig Cruañes, Rodrigues Bravo, mesmo comentando algumas nuances da perspectiva social, também privilegia as perspectivas objetiva e subjetiva da noção de documento.

Para finalizar esta etapa é relevante mencionar que mesmo sendo notória a perspectiva física em todos os contextos analisados, fica patente que os autores preferem destacar, ora a nuance subjetiva, que valoriza o papel do sujeito na atribuição do que pode ou não ser um documento; ora a nuance social, em que se expande a visão,

\footnotetext{
${ }^{27}$ A autora faz questão de distinguir a noção de documento de fonte de informação. Enquanto a noção de documento estaria intimamente vinculada a uma intenção comunicativa e potencialmente informativa, a fonte de informação, num âmbito mais amplo e geral seria qualquer ente do qual alguém, em algum momento, extrairia informação, tendo sido ou não concebida para esse fim (RODRIGUEZ BRAVO, p.86, 2002).
} 
considerando não só o sujeito isolado em sua produção/apreensão de sentido, mas o contexto e a situação espaço-temporal em que está envolvido.

Depois de comentarmos os contextos analisados $\mathrm{e}$ as suas principais perspectivas, apresentaremos a etapa final da análise terminológica, a síntese. A partir do cotejamento terminológico foi elaborada uma síntese dos contextos analisados:

Documento -"A noção de documento pode ser entendida a partir de três perspectivas complementares: a objetiva, a subjetiva e a social. Na primeira, o documento é visto como um objeto material, com função de suporte ou meio portador de uma mensagem informativa. Na perspectiva subjetiva, considera-se o papel do documento em representar um conteúdo informativo que é ativado apenas quando um sujeito lhe atribui sentido, destacando-se aí a intenção comunicativa do sujeito receptor. E na última, destaca-se a função social do documento, marcada pelo acesso e preservação do conhecimento, bem como pelo fato dele servir como meio para as relações sociais. Além disso, considerando que o documento é utilizado na comunicação em um espaço e tempo determinados, sua existência está intimamente vinculada aos sujeitos (emissor e receptor) e ao contexto em que foi criado".

\subsection{A noção do termo "informação"}

A análise do termo informação, de forma geral, assim como do termo documento, permitiu que retomássemos algumas das definições que foram apresentadas no capítulo anterior. O que pode ser destacado do recorte dos autores são dois aspectos: a aproximação da noção de informação com a noção de documento, principalmente observada na elaboração da própria definição de informação; e a ênfase social dada à noção de informação. Com intuito de ilustrar o processo de análise dos contextos, elaboramos um quadro comparativo das perspectivas de cada autor, a partir de trechos da ficha de análise:

\begin{tabular}{|l|l|l|l|}
\hline Autor/ano & Perspectiva objetiva & Perspectiva subjetiva & Perspectiva social \\
\hline Fondin (2005) & $\begin{array}{l}\text { “[...] entendem o } \\
\text { conceito do } \\
\text { conteúdo integrado } \\
\text { à palavra } \\
\text { informação como } \\
\text { uma ferramenta". }\end{array}$ & $\begin{array}{l}\text { conteúdo de uma } \\
\text { mensagem”. }\end{array}$ & $\begin{array}{l}\text { “[...] é, portanto } \\
\text { objeto de estudo } \\
\text { para todas as } \\
\text { ciências, porque é } \\
\text { um objeto social”. }\end{array}$ \\
& & & \\
\hline
\end{tabular}




\begin{tabular}{|c|c|c|c|}
\hline Latour (2008) & $\begin{array}{l}\text { "[...] um veículo } \\
\text { que denominamos } \\
\text { muitas vezes forma, } \\
\text { mas que, para } \\
\text { insistir em seu } \\
\text { aspecto material, eu } \\
\text { chamo de } \\
\text { inscrição". }\end{array}$ & $\begin{array}{l}\text { "A Informação não } \\
\text { é inicialmente um } \\
\text { signo, e sim o } \\
\text { carregamento em } \\
\text { inscrições cada vez } \\
\text { mais móveis e cada } \\
\text { vez mais fiéis, de } \\
\text { um maior número } \\
\text { de materiais". }\end{array}$ & $\begin{array}{l}\text { "A informação não } \\
\text { é um signo, e sim } \\
\text { uma relação } \\
\text { estabelecida entre } \\
\text { dois lugares: o } \\
\text { primeiro, que se } \\
\text { torna uma periferia, } \\
\text { e o segundo, que se } \\
\text { torna um centro". }\end{array}$ \\
\hline Cornelius (2002) & & $\begin{array}{l}\text { "A informação é o } \\
\text { significado da } \\
\text { mensagem [...] o } \\
\text { conteúdo da } \\
\text { informação é uma } \\
\text { construção } \\
\text { subjetiva do } \\
\text { destinatário". }\end{array}$ & $\begin{array}{l}\text { “[...] não há } \\
\text { nenhuma } \\
\text { informação } \\
\text { independente de } \\
\text { nossas práticas } \\
\text { sociais [...] está } \\
\text { envolvida em uma } \\
\text { rede de } \\
\text { significados, que } \\
\text { são socialmente } \\
\text { negociados e que se } \\
\text { combinam”. }\end{array}$ \\
\hline Ros García (2000) & $\begin{array}{l}\text { "[...] a mensagem } \\
\text { informativa, é aquela } \\
\text { que consegue } \\
\text { sobreviver -graças ao } \\
\text { suporte documental e } \\
\text { as técnicas } \\
\text { documentárias- mais } \\
\text { distante do espaço e } \\
\text { do tempo". }\end{array}$ & $\begin{array}{l}\text { "[...] a chave do arco } \\
\text { representado pelo } \\
\text { processo informativo } \\
\text { é a mensagem". }\end{array}$ & \\
\hline Day (2000) & $\begin{array}{l}\text { "[...] a informação } \\
\text { tem, entre outras } \\
\text { qualidades, a de ser } \\
\text { mensurável e } \\
\text { quantificável } \\
\text { factual". }\end{array}$ & $\begin{array}{l}\text { "Estas qualidades } \\
\text { são refletidas no } \\
\text { objetivo de } \\
\text { transmissão de } \\
\text { informações, ou } \\
\text { seja, o envio e } \\
\text { recebimento de } \\
\text { uma mensagem". }\end{array}$ & $\begin{array}{l}\text { "[...] é entendida } \\
\text { como um conceito } \\
\text { cultural [...] pode } \\
\text { ser denominada } \\
\text { como "Informação } \\
\text { global" da } \\
\text { sociedade". }\end{array}$ \\
\hline $\begin{array}{l}\text { Rodríguez Bravo } \\
(2002)\end{array}$ & $\begin{array}{l}\text { “[...] aquela que } \\
\text { considera a } \\
\text { informação uma } \\
\text { realidade objetiva, }\end{array}$ & $\begin{array}{l}\text { "A aproximação } \\
\text { subjetiva que } \\
\text { considera a } \\
\text { informação como }\end{array}$ & \\
\hline
\end{tabular}




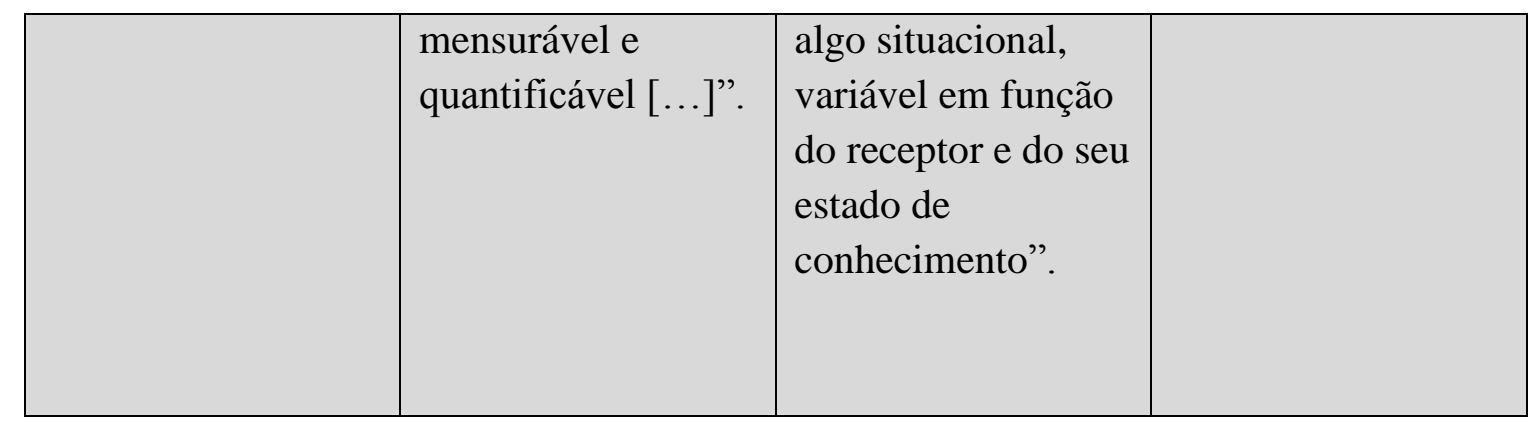

Quadro 13- Quadro comparativo das perspectivas

A noção de informação elaborada pelos autores franceses, mesmo com as particularidades de cada um, têm em comum o fato de aproximarem a noção de “informação" e de "documento". Uma explicação possível para tal percepção talvez seja o fato da linha francófona considerar o conceito de Informação-Documentação ${ }^{28}$, o que segundo Metzer (2006) seria uma expressão criada a fim de "evitar o caráter redutor do termo único Documentação" (METZER, p. 43, 2006).

Fondin (2005), ao definir informação, parte do conceito clássico, como conteúdo de uma mensagem. Tal denominação, por seu caráter genérico, poderia tornar-se objeto de estudo de diversas áreas do conhecimento, já que diferentes tipos de especialistas poderiam utilizá-la como uma "ferramenta" para seus estudos. Segundo essa perspectiva o autor expande a noção de informação como "sinônimo de objeto social", o que tem como consequência o fato dele não "pertencer de direito" a nenhuma ciência, já que poderia ser utilizado por qualquer uma. Diante desse cenário, o autor explica que na verdade quando a Ciência da Informação fala da noção de "informação" seus especialistas enxergam um escopo mais particular, "a informação intencional”.

Fondin (2005) explica que a informação intencional seria o objeto clássico da Ciência da Informação, já que teria o valor de "conhecimento comunicado" - ideia também presente na Comunicação. A informação intencional poderia ser caracterizada por dois critérios: a obsolescência (nível de interesse de alguma coisa no decorrer do tempo), podendo assim ser durável ou efêmera; e o uso (critério não inerente à coisa em si, mas que pode ser atribuído para se explorar a informação). Mais adiante em seu texto

\footnotetext{
${ }^{28}$ Sobre a Informação-Documentação: “ elle est d'abord une activité e service, que est fondée sur dês compétences et des savoirs, qui fait appel à un matériel et qui s'appuie sur une technologie. Elle est aussi un objet d'enseignement et de recherche, qui englobe les processus d'accés à la documentation et à l'information et les mécanismes de leur traitament, les matérieles et les techniques documentaires, les pratiques professionnelles et leur d'exercice.Cette activité d'information-documentation s'incrit dans tous les domaines de la vie sociale, culturalle et économique (METZER, p. 43, 2006).
} 
o autor ressalta que a informação não pode ser qualquer conteúdo fixado em um suporte, já que cabe a cada leitor em seu espaço social atribuir-lhe um sentido. Assim a informação não deveria ser vista como um objeto físico, mas uma "objeto eminentemente social" (FONDIN, p.11, 2005). Dessa forma, constatamos que Fondin destaca tanto a perspectiva subjetiva, por considerar a noção de "informação intencional"- diretamente vinculada a um sujeito emissor -, como a visão social, já que não se "esquece" de inserir o sujeito receptor num contexto social.

Outro autor que aproxima a noção de informação e documento é Latour (2008). Ao definir informação, destaca primeiramente seu aspecto material e prático, falando metaforicamente da noção de documento:

A informação não é um signo, e sim uma relação estabelecida entre dois lugares: o primeiro, que se torna uma periferia, e o segundo, que se torna um centro, sob a condição de que entre os dois circulem um veículo que denominamos muitas vezes forma, mas que, para insistir em seu aspecto material, eu chamo de inscrição (LATOUR, p.22, 2008).

Latour $^{29}$ (2008), contrário a uma visão dualista, não se centra em apenas uma perspectiva para enxergar a informação, mas prefere vê-la sob o viés da "caótica" dinâmica das relações, numa visão, portanto, mais pragmática ${ }^{30}$. Esse olhar relacional do autor está presente em grande parte de seus estudos, refletindo sua crítica à visão dualista da ciência que separa o conteúdo científico do contexto social. Segundo ele: "é como se contexto e conteúdo fossem dois líquidos que podemos fingir misturar pela agitação, mas que se sedimentam tão logo deixados em repouso" (Latour; Woolgar, p.20, 1997, apud Freire, p.48, 2006). Analogamente, a noção de informação, assim como aponta o autor, não poderia dissociar-se da noção de documento, já que juntas desempenham uma função social e prática. Dessa forma, Latour dá a mesma

\footnotetext{
29 "Na França, Michel Callon e Latour vem propondo a criação de uma nova disciplina transversal, situada na interseção da Sociologia e das Ciências Exatas, assumindo como objeto de estudo os processos que emergem da inovação científica e técnica: a chamada Antropologia das Ciências" (FREIRE, p.49, 2006).

30 "Do ponto de vista metodológico, Latour afirma que a única maneira de compreender a realidade dos estudos científicos é acompanhar os cientistas em ação, já que a ciência está fundada sobre uma prática, e não sobre ideias. Para isso, é preciso prestar atenção aos detalhes da prática científica" (FREIRE, p.50, 2006).
} 
importância para a perspectiva objetiva e social, deixando bem evidente em seu texto a discordância em seccionar aquilo que para ele só funcionaria em conjunto.

Quanto aos autores anglo-escandinavos, assim como no documento, a ênfase é a perspectiva social. É evidente que são lembradas a nuance objetiva e a subjetiva, esta última destacada por associar-se ao sentido atribuído a uma mensagem, construção do sujeito. Todavia, esse sujeito não está isolado em suas escolhas, pois está inserido numa sociedade e é fruto de um contexto sociocultural, portanto, a noção de informação também acaba sendo influenciada pelo contexto.

Já Cornelius (2002) afirma que a informação "é o significado da mensagem, juntamente com todas as informações contextuais relevantes à disposição do destinatário" (CORNELIUS, p.393, 2002). Nessa definição, o autor destaca que o conteúdo da informação é uma construção subjetiva do destinatário, embora socialmente negociada. Mesmo resgatando a perspectiva construtivista, que ressalta a singularidade da experiência individual de informação, o autor lembra que não há nenhuma informação independente de nossas práticas sociais. A informação, portanto, seria negociada na interação em relação a outros sentidos, envolvendo para isso uma dinâmica rede de significados construídos a partir do processo de comunicação, que se combinaria para influenciar ou determinar o conteúdo informacional.

Day (2000) também enxerga a informação como um produto das práticas sociais, ressaltando o papel da informação como um conceito cultural, noção que para ele seria elementar na conjuntura da sociedade atual. As outras perspectivas também são contempladas: a objetiva destacando a informação como algo quantificável, mensurável e factual, características que contribuiriam no processo comunicativo e no envio e recebimento de mensagens com o mínimo de interferência possível; e a subjetiva destacando o papel do emissor na construção do conteúdo informativo a partir de sua intencionalidade. Assim, podemos perceber que Day (2000) tem tanto uma visão objetiva quanto subjetiva da informação, de modo similar à perspectiva de Hjorland (2007), além da perspectiva social, como ressalta Capurro (2003).

Quanto aos autores espanhóis destacamos dois representantes: Ros García (2000) e Rodríguez Bravo (2002). Ros García (2000) começa afirmando que a informação é a base para o conceito de Documentação, já que o processo documentário é um processo informativo. O autor fala da noção de "informação documentária", que 
seria uma mensagem informativa passível de ser recuperada por estar registrada e conservada em um suporte documental. O suporte documental seria a garantia de sobrevivência da mensagem informativa no tempo e espaço, podendo ser recuperada. Logo, a mensagem informativa (informação) e o suporte documental (documento) estariam numa relação íntima em que forma e substância se completariam. Ros García, portanto, assim como os autores da linha francófona, aproxima as noções de documento e informação, enxergando-as como elementos complementares no âmbito documentário:

Desde el momento en que se incorpora el mensaje informativo al soporte físico constituyendo el documento hasta el momento en que el mensaje alimenta la creación de un autor dando lugar a otro nuevo documento, y así en una cadena sin fin, en la que el documento aparece como factor siempre potenciador y semilla imprescindible de nueva información sin límites en el tiempo constituyen la noción de documento. Así, el documento, informativamente hablando, significa la conserva y la difusión del mensaje y la tarea documentaria se erige como un modo de concentración de mensajes incorporados a soportes físicos con el fin de realizar con seguridad y rapidez su comunicación o difusión. Sin embargo, el mensaje documentario es todavía más (ROS GARCÍA, p.5, 2000).

O fato de o autor retomar a própria noção de documento nos dá a dimensão da importância e da proximidade dos termos. Ros García (2000) privilegia a perspectiva objetiva da informação, ou seja, sua funcionalidade associada ao documento. Para isso o autor fala de seu papel comunicativo, considerando o fato de ser uma "mensagem portadora" de potencial conhecimento, propriedades da perspectiva subjetiva, embora evidencie o valor pragmático da noção de informação.

Rodríguez Bravo (2002) por sua vez, além da perspectiva objetiva, também ressalta a subjetiva. A autora dedica um capítulo de sua obra para falar da noção de informação. Como já foi dito, a autora faz uma revisão de literatura sobre o termo, das origens até a visão de autores mais contemporâneos, identificando basicamente duas vertentes para a sua definição, a informação objetiva e a informação subjetiva ${ }^{31}$. Na perspectiva objetiva enxerga a informação no âmbito de uma realidade mais concreta - quantificável, mensurável e objetiva - considerada como uma mensagem registrada em um suporte. Já na visão subjetiva, a noção de informação varia em função do receptor e de seu estado de conhecimento. Nesse aspecto a autora relembra o caráter da informação potencial, mensagem embutida de uma intenção comunicativa/informacional que pode transformar

\footnotetext{
${ }^{31}$ Essa opção que trata a informação sob duas vertentes, a subjetiva e objetiva, também já foi observada na revisão de literatura do capítulo anterior, desenvolvidas por Hjorland (2007).
} 
o conhecimento e a realidade de um sujeito. Tal aspecto já fora de certa forma mencionado quando falamos de documento, o que ratifica a proximidade entre as duas noções.

Depois de observarmos os contextos enunciados pelos autores, podemos afirmar que, do mesmo modo como em relação ao documento, a noção de informação é tratada preponderantemente sob a perspectiva social, geralmente associada ao contexto que envolve o sujeito-emissor ou receptor da informação. Contudo, o aspecto objetivo, muito relacionado ao documento também é evidenciado, até mais que o subjetivo.

A partir das observações realizadas anteriormente - vertentes reunidas por língua e principais perspectivas de cada autor - podemos elaborar uma síntese dos contextos analisados:

Informação - "Pode ser entendida a partir de três perspectivas complementares: a objetiva, a subjetiva e a social. Na primeira ressalta-se a ideia de informação como uma mensagem informativa que está registrada em um suporte (documento), destacando-se sua materialidade e o fato de ser mensurável, quantificável e factual. Na perspectiva subjetiva privilegia-se a construção da informação pelo sujeito, observando assim a informação como algo que varia em função do receptor e de seu estado de conhecimento. Já na perspectiva social fica em destaque a informação como rede de significados socialmente negociados, dependentes de situações comunicativas e do contexto".

Depois de verificarmos as noções de documento e informação observadas a partir do cotejamento terminológico tentaremos, no próximo capítulo, a partir da elaboração de sínteses, refletir sobre as relações entre os termos "documento" e "informação". 


\section{Capítulo - Resultados da análise dos termos documento e informação}

\subsection{Introdução}

No capítulo anterior, após a análise terminológica, chegamos às noções de 'documento' e 'informação', observadas separadamente. Nesse capítulo, a partir das sínteses das noções tentaremos verificar as principais aproximações e distinções entre esses dois termos e como eles podem contribuir para a identificação dos traços que ajudem a caracterizar o campo da Ciência da Informação.

Retomemos primeiramente a noção de documento e informação, elaboradas a partir da análise terminológica:

Documento -"A noção de documento pode ser entendida a partir de três perspectivas complementares: a objetiva, a subjetiva e a social. Na primeira, o documento é visto como um objeto material, com função de suporte ou meio portador de uma mensagem informativa. Na perspectiva subjetiva, considera-se o papel do documento em representar um conteúdo informativo que apenas é ativado quando um sujeito lhe atribui sentido, destacando-se aí a intenção comunicativa do sujeito. E na última, destaca-se a função social do documento, marcada pelo acesso e preservação do conhecimento, bem como o fato dele servir como meio para as relações sociais. Além disso, considerando que o documento é utilizado na comunicação em um espaço e tempo determinados, sua existência está intimamente vinculada ao sujeito e ao contexto em que foi criado".

Informação - "Pode ser entendida a partir de três perspectivas complementares: a objetiva, a subjetiva e a social. Na primeira ressalta-se a ideia de informação como uma mensagem informativa que está registrada em um suporte (documento), destacando-se sua materialidade e o fato de ser mensurável, quantificável e factual. Na perspectiva subjetiva privilegia-se a construção da informação pelo sujeito, observando assim a informação como algo que varia em função do receptor e de seu estado de conhecimento. Já na perspectiva social fica em destaque a informação como rede de significados socialmente negociados, dependentes de situações comunicativas e do contexto".

Uma primeira constatação na comparação entre os termos é o fato de que eles possuem traços comuns, ou seja, podem ser visualizados a partir das perspectivas objetiva, subjetiva e social, inspiradas nos paradigmas de Capurro (2007). É claro que cada noção possui sua particularidade, mas o fato de poderem ser encaradas por visões próximas nos faz perceber como podem estabelecer entre si uma inter-relação. Outra constatação relevante é perceber que, de forma geral, os autores mencionam as três perspectivas, enfatizando a proximidade entre elas, com destaque para Lund (2009), que não só as apresenta ressaltando a inter-relação das perspectivas como lembra que mais importante do que considerar cada uma isoladamente é enxergar "como" elas se relacionam. 
Antes de evidenciarmos o "como", perpassaremos pelas perspectivas encontradas nas noções de documento e informação a fim de melhor compreender a inter-relação dos traços semânticos.

\subsection{Proximidades e distinções entre as noções}

Dentre as perspectivas observadas, é notório verificar que há certa predileção dos autores pelo viés social. Mesmo considerando as outras perspectivas, que ora se aproximam, ora se distanciam da perspectiva social, não há como negar que as noções de documento e informação, antes de tudo são frutos de nossas práticas sociais, logo estão diretamente vinculados a um contexto. Os documentos, por exemplo, considerados entidades sociais vivas, estão inseridos em redes sociais que viabilizam a coordenação, cooperação e articulação social das sociedades contemporâneas (FROHMANN, 2004). A partir de tal noção percebemos que as funções sociais dos documentos ocorrem em situações bem definidas, tanto no documento em seu caráter primário (criado com um propósito específico a fim de "representar" as relações sociais e institucionais), como no caráter secundário (quando se atribui seu valor como objeto histórico-cultural). Além disso, a perspectiva social evidencia o documento como uma "manifestação concreta significante", ou seja, no âmbito de uma práxis social específica, é capaz de direcionar a construção dos conhecimentos, a partir da informação, no seio de uma comunidade discursiva e numa situação comunicativa inserida num tempo/espaço específicos (COURBIÈRES, 2008).

A informação, por sua vez, como fenômeno social, é uma construção coletiva e intersubjetiva (produto de vários sujeitos e construída coletivamente). Assim, a necessidade de informação, que não é inerente ao indivíduo - já que sua existência está condicionada a um estado de conhecimento insuficiente, é construída por um sistema social (LE COADIC, 2002). Dessa forma a necessidade de informação é dependente não somente do sistema de informação, cujo indivíduo é membro, mas também dos sistemas sociais, culturais, cognitivos e profissionais nos quais eles aparecem.

A informação está envolvida em uma rede de significados que são socialmente negociados pelas comunidades discursivas ${ }^{32}$ e que se combinam para influenciar ou

\footnotetext{
${ }^{32}$ A noção de comunidade discursiva é desenvolvida por Capurro (2007) para falar de um grupo social responsável pela pré-compreensão de uma mensagem, já que ao compartilharem "formas de se enxergar o mundo", teriam o papel de "criar as referências" para a seleção de sentido para seu grupo.
} 
determinar seu "conteúdo informacional", criando referências de sentido para uma coletividade. Como esse conteúdo está registrado no documento, podendo ser construído ou encontrado em uma situação comunicativa localizada no tempo/espaço, é inseparável tanto do sujeito como do contexto em que foi construído ou reconstruído.

A noção de comunidade discursiva está vinculada tanto a elementos de caráter subjetivo como social. No primeiro caso, considera as particularidades do sujeito (usuário/conceptor), principalmente ligadas à intenção e finalidade comunicativa do indivíduo em determinando contexto. Já na perspectiva social, amplia-se tal visão para o grupo em que o sujeito se insere, considerando assim as necessidades e intenções dessa comunidade num determinando contexto. Contudo, às vezes é difícil delimitar onde começa e termina uma comunidade discursiva, ou mesmo dizer que uma intenção/finalidade comunicativa é fruto "apenas" da visão de um sujeito. Isso ocorre porque vivenciamos diferentes relações sociais, com interesses e necessidades distintas e dinâmicas, logo, falar do "pertencimento" a apenas uma comunidade discursiva, ou mesmo considerar um único sujeito como o responsável por uma finalidade comunicativa, pode ser redutor demais. Assim, há várias comunidades discursivas e nós, como sujeitos de um coletivo dinâmico, fazemos parte dessas diferentes comunidades, já que somos "fruto" dessas inter-relações sociais. Assim, o que acaba norteando o "pertencimento" a alguma comunidade discursiva é o contexto em que estamos inseridos.

A segunda perspectiva mais ressaltada foi a objetiva, tendo uma maior preponderância na noção de informação, principalmente associada à noção de documento; e na noção de documento a perspectiva objetiva se situa muito próxima da perspectiva subjetiva, destacando-se a escolha feita pelos autores espanhóis. No caso do documento a perspectiva objetiva está ligada não apenas ao aspecto físico, evidenciado pelo suporte, mas por uma materialidade ampliada nas noções de meio, estrutura e função do documento. Já na informação, há autores que preferem enfatizar a perspectiva objetiva, por associar a noção de informação com documento, destacando assim seu caráter mais tangível, quantificável e mensurável, perceptível a partir da materialização da informação no documento.

Nessa linha que valoriza a proximidade entre informação e documento, ressaltada pela perspectiva objetiva, temos Michel (2000). O autor afirma que a 
informação em si não é um objeto tangível e objetivo, manipulável e perceptível, ou seja, sua materialidade só se manifesta através de uma mediação documentária. Assim, seria o documento (físico/real ou eletrônico/virtual) que fixaria ou materializaria a informação num dado momento permitindo sua difusão e mudança. Nesse ponto, para marcar essa inter-relação, Michel (2000) prefere denominar “informaçãodocumentação", expressão na qual sobressai a noção de duas faces de um mesmo e único elemento, que tem em uma face a informação e na outra o documento.

Essa visão de que a noção de documento e de informação possa ser visualizada como um elemento comum, encarada sob ângulos diferentes, já foi observada por outros autores da área, como Smit (2000): "Em resumo, documento e informação são as duas faces da mesma moeda, sendo que uns prestam mais atenção a uma face, outros à outra, mas não é possível descolar as faces da moeda"; e Rodriguez Bravo (2002), que afirma que o documento pode ser definido como um objeto que serve como suporte de informação e de difusão, constituído de duas noções inseparáveis: uma de natureza material (o objeto como suporte) e outra conceitual (a informação).

A perspectiva subjetiva, principalmente para os autores espanhóis, ao definir a noção de documento, se mostra muito próxima à perspectiva objetiva. A ideia de um documento visto genericamente como um suporte, per si, não tem nenhuma função documentária. No entanto, ao servir de suporte para uma mensagem, com intenção comunicativa e potencialmente informativa para um receptor, "ganha" seu status de documento, evidenciando assim a perspectiva subjetiva. A informação, por sua vez, considerada "mensagem potencialmente informativa" e até "fluxo" para alguns autores, no âmbito da Ciência da Informação, precisa estar registrada em um suporte. Não que a informação gerada em situações do discurso oral seja ignorada, mas no contexto da Ciência da Informação, em que suas práticas estão voltadas à organização, acesso e recuperação da informação, é imprescindível que essa informação esteja materializada para que possa ser disponibilizada.

A perspectiva subjetiva aparece ainda na noção de informação associada à função de "gerar conhecimento". Tal papel é observado na elaboração do conteúdo informacional, feito a partir de uma construção subjetiva de um indivíduo, que em contato com esse conteúdo tem suas estruturas mentais afetadas e até modificadas, podendo potencialmente "gerar conhecimento" (ARAÚJO, 2010). Contudo, essa perspectiva, por ser muitas vezes aproximada da visão cognitiva, é criticada por grande 
parte dos autores, ao restringir-se ao sujeito e ignorar a perspectiva social. Capurro (2007) é um desses autores, que mesmo apresentando as três visões de informação (física, cognitiva e social) enfatiza a importância de se considerar o papel das comunidades discursivas para o entendimento do conceito da informação, o que segundo ele é fruto antes de tudo de práticas sociais e não situações isoladas de transferência de conhecimento entre indivíduos.

Como já foi mencionado anteriormente, as perspectivas não são apresentadas de forma isolada, mas de modo inter-relacional. Mesmo com a predileção dos autores por alguma das visões, fica nítida a percepção de que são nuances que devem ser encaradas complementarmente. No caso da perspectiva subjetiva, por exemplo, ela aparece não para ser considerada individualmente, mas para relacionar-se com as demais. No âmbito do documento, por exemplo, ao ressaltar-se a noção de intencionalidade comunicativa, verifica-se que mesmo partindo de um indivíduo a perspectiva subjetiva é determinada por consenso social, ou seja, ocorre pela validação coletiva dessa intencionalidade. Assim, mesmo considerando a intenção e a perspectiva do sujeito (produtor/criador e receptor), é no viés social que se amplia a noção do sujeito isolado, e considera-se a visão de uma comunidade discursiva (ARAÚJO, 2010). Os documentos são produzidos/atribuídos a partir da intencionalidade de uma comunidade discursiva, e se organizam sistematicamente em dispositivos a fim de viabilizar seu uso social (MARCONDES, 2010).

$\mathrm{Na}$ tentativa de representar essa inter-relação das perspectivas que envolvem as noções de documento e informação, apresentamos abaixo uma ilustração. Nela podemos verificar que as perspectivas são dinâmicas e se amalgamam, ficando difícil delimitá-las ou separá-las. Além disso, o contexto é elemento-chave que as envolve, dando-lhes as nuances da situação comunicativa no tempo-espaço. 


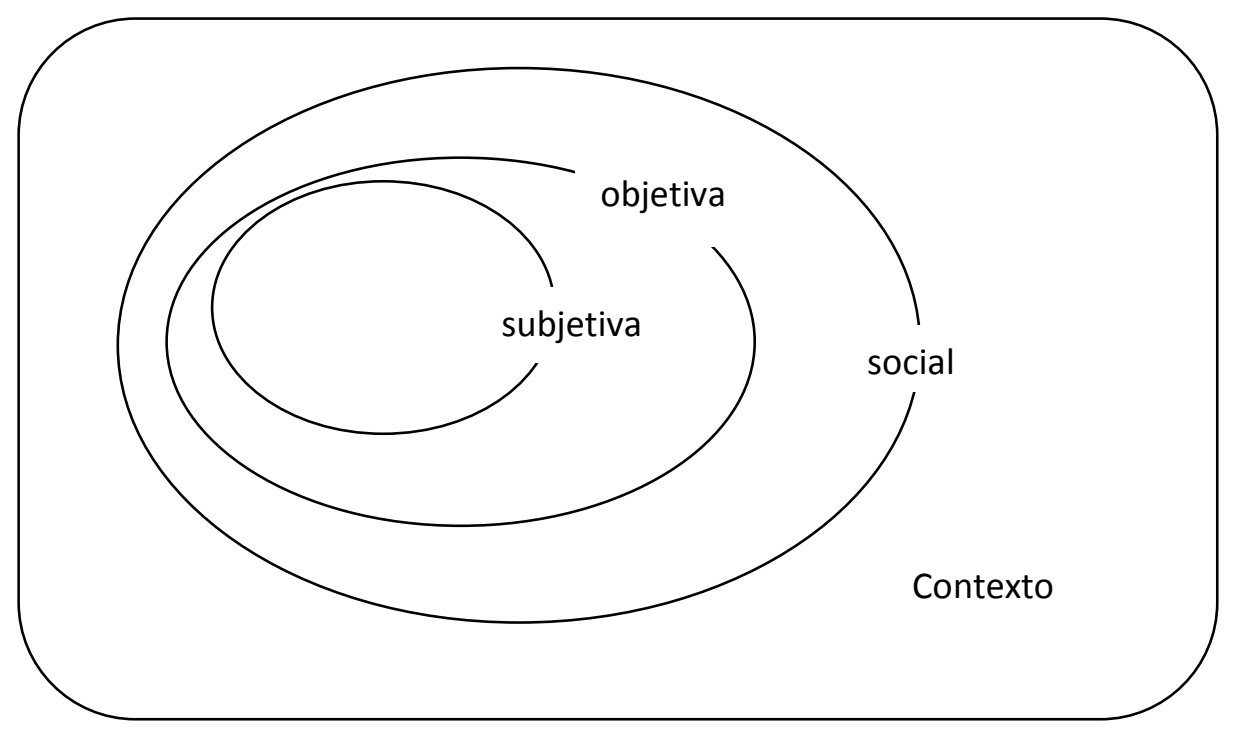

Representação gráfica das perspectivas que envolvem as noções de documento e informação

\subsection{Os termos documento e informação e a Ciência da Informação}

Diante do que foi apresentado, tanto na revisão de literatura como na análise terminológica podemos chegar a algumas conclusões acerca das noções de documento e informação para a Ciência da Informação.

Os conceitos de "documento" e "informação", mesmo observando sua natureza e funções específicas, demonstram notória proximidade no âmbito de Ciência da Informação, tanto por apresentarem traços semânticos semelhantes (perspectiva objetiva, subjetiva e social), como pelo fato de atuarem conjuntamente no escopo do domínio em questão. O fato da informação como fluxo "naturalmente" precisar da materialidade do documento para se difundir e ser acessada, ou mesmo o documento, que só transcende sua "materialidade" ao tornar-se meio pelo qual a informação se consubstancia, são evidências de que entre documento e informação não há apenas proximidade, mas em certa medida uma relação simbiótica.

A noção de simbiose provém da Biologia, da subárea da Ecologia, para determinar as relações interespecíficas em que organismos de espécies diferentes se associam intimamente, de forma mutuamente vantajosa, em que cada um contribui positivamente para a sobrevivência do outro. Analogamente, documento e informação, no domínio da Ciência da Informação, podem ser encarados como elementos de uma relação simbiótica, pois mesmo considerando suas particularidades, é na conjunção de 
suas noções que temos uma visão mais ampla da função de cada termo no âmbito da Ciência da Informação.

Nessa perspectiva, os conceitos documento e informação contribuem com as principais funções da Ciência da Informação: a organização, o acesso e a recuperação da informação. Se pensássemos, por exemplo, na noção de informação isolada, ou como alguns autores afirmam, como "o objeto" da Ciência da Informação, não teríamos efetivamente a concretização das práticas essenciais da área a não ser considerando que o "fluxo" parte de algo "materializado". Essa materialização, como já foi comentado anteriormente, não é sinônimo de um objeto concreto, ou apenas algo delimitado pela forma. O documento, a partir de sua estrutura manifesta é capaz de fazer com que a informação, num primeiro momento "fluxo", se materialize e com isso possa ser acessada e recuperada, assim estão envolvidas as noções de meio, estrutura e função do documento.

Além da nítida proximidade mais objetiva, podemos retomar a perspectiva subjetiva, focada na intencionalidade comunicativa de um sujeito, ou mesmo a perspectiva social, que amplia as relações e intenções comunicativas no âmbito de uma comunidade discursiva. Em qualquer uma delas podemos notar a complementaridade entre as noções de documento e informação. Assim, a visão simbiótica ressalta a interrelação das perspectivas apresentadas, o que valoriza as práticas da Ciência da Informação. Dessa forma, os processos de organização, acesso e recuperação informacional não devem ser vistos por um viés estratificado ou facilmente dedutível de uma visão apenas. Ao contrário, no âmbito da contemporaneidade devemos olhar as práticas científicas não só mais relativamente, mas considerando a dinamicidade e as particularidades do contexto de produção e difusão dessas práticas. Assim, documento e informação fundidos podem ser visualizados em suas diferentes perspectivas, a partir do contexto das comunidades discursivas.

Além disso, a visão simbiótica também sugere outra forma de encararmos as noções de documento e informação. Considerando que mesmo distintos, atuam ativamente numa ação de cooperação mútua e associação íntima. Assim, podemos supor que tal conjunção de forças resulte em um terceiro elemento, a informaçãodocumentária ou documento-informação. Uma analogia interessante poderia ser feita com a Linguística, que tem como objeto o signo linguístico. Para ela, tal noção também 
poderia ser denominada "simbiótica", já que tanto o plano de expressão (significante), como o plano do conteúdo (significado), são "faces da mesma moeda", pois somente integrados é que caracterizam a noção de signo linguístico. No âmbito da Ciência da Informação, as noções de documento e informação também podem ser visualizadas de modo semelhante, já que isoladamente perdem parte do que são em conjunto. Assim, a conjunção nas noções constituiria um conceito chave para a área, "o documentoinformação", ou "informação-documentária", como utilizam os franceses ${ }^{33}$, e, de forma semelhante, no Brasil, a exemplo de Kobashi (1994) entre outros autores do Grupo $\mathrm{Temma}^{34}$.

A escolha pela denominação mais adequada para esse terceiro elemento da conjunção das noções constituiria outro trabalho. No entanto vamos discutir brevemente algumas diferenças das expressões. No caso da expressão "documento-informação", o termo "documento" é determinado pelo termo informação, ou seja, o primeiro tem valor de substantivo, enquanto o segundo o "caracteriza". Nessa concepção parte-se da perspectiva objetiva, porém evidencia-se o poder qualificativo do termo "informação" que potencializa o valor do documento nas perspectivas subjetiva e social. Já na expressão informação-documento ocorre o inverso, ou seja, parte-se da perspectiva mais subjetiva e social, associadas ao termo "informação", e tem-se o atributo "documentário" a fim de delimitar mais objetivamente a primeira noção.

\footnotetext{
${ }^{33} \mathrm{O}$ vocábulo "informação documentária" (information documentaire) é largamente usado e reconhecido por documentalistas franceses no final da década de 80. A expressão surge com a necessidade de se qualificar a informação num contexto de rápida mudança tecnológica e certo abandono das denominações associadas à Documentação nas últimas décadas do século XX. Assim, documentalistas do SNEA (Societé Nationale Elf Aquitane) sob a égide do DCIC (Département Central de l'Information Documentaire) utilizam adjetivos a fim de qualificar as noções de informação. Dessa forma, no âmbito temático, além da noção de informação documentária, formulam a noção de informação tecnológica, informação científica, informação especializada; ou mesmo no âmbito da forma as noções de informação textual, informação digital, informação audiovisual, etc. (JAKOBIAK, 1988).

${ }^{34}$ O Grupo TEMMA é reconhecido nacionalmente como o único grupo formalmente voltado para as pesquisas relacionadas à organização da informação: seus pesquisadores orientam na pós-graduação e atuam na graduação em temáticas relacionadas aos objetivos do Grupo e sua produção bibliográfica constitui bibliografia básica para os cursos de graduação e pós-graduação brasileiros e espanhóis. O grupo vem diversificando o escopo de suas pesquisas, investindo particularmente nos estudos de terminologia aplicada à organização e transferência da informação; processos de leitura que sustentam a análise documentária e a reflexão acerca da linguagem de especialidade da Ciência da Informação. Informações em: https://sistemas.usp.br/tycho/gruposPesquisaObter?codigoGrupoPesquisa=0067607UVP2I76.
} 
Tais visões já apareceram indiretamente na revisão de litertatura, a exemplo de Ortega (2009b), retomando Frohmann (2004), ao falar de informatividade, um possível neologismo para área, que estaria ressaltando o valor da informação como um "atributo" ligado à noção de documento; ou mesmo Michel e outros autores da linha francesa, que optaram pela expressão "informação-documento", por partirem do caráter mais subjetivo e social para o objetivo, dando ao documento esse papel "delimitador".

Independentemente de qual expressão for escolhida é notório perceber que esse terceiro conceito formado pelas noções de documento e informação demonstra não só a potencialidade de ser o elemento "propulsor" do fazer científico da Ciência da Informação, mas principalmente, por seu caráter dinâmico e multifacetado, resultado da associação das perspectivas conceituais e das particularidades contextuais, ser um exemplo cabal de um provável objeto científico da pós-modernidade. 


\section{Considerações finais}

A Ciência da Informação, por sua origem, de certa forma recente, e pelo desenvolvimento de seu escopo no âmbito das fragmentações e relativizações do contexto pós-moderno, é uma área que ainda está se constituindo. No intuito de delinear melhor essa área. Procedemos a análise terminológica dos termos "documento" e “informação" a fim de identificar aspectos para a caracterização identitária do campo.

A partir da análise terminológica contatou-se a evidente proximidade entre os termos, o que pôde ser evidenciado pela semelhança de traços semânticos observados na etapa de análise e síntese das noções. As perspectivas objetiva, subjetiva e social, inspiradas nos paradigmas de Capurro (2007), apareceram tanto no termo "documento", como no termo "informação". Embora pudéssemos verificar pelas definições as nuances particulares de cada termo, foi possível observar, na análise terminológica, a existência de intersecção entre as perspectivas, o que corroborou à aproximação entre os termos no escopo da Ciência da Informação.

Essa "associação íntima", denominada aqui analogamente à Biologia como uma "visão simbiótica" das noções de documento e informação, demonstra o caráter dinâmico da relação entre os termos. Além disso, ao associarmos simbioticamente documento e informação, podemos chegar a um terceiro elemento, o "documentoinformação" ou "informação-documento", que nos revela em sua natureza dialógica e contextual traços da perspectiva científica da contemporaneidade. Assim, além de corroborarem às principais práticas da Ciência da Informação - organização, acesso e recuperação informacional-, ainda podemos verificar que tanto as perspectivas que compõem as noções de documento e informação, como o terceiro elemento que concebem, revelam um conjunto de traços que permitem compor o quadro de configuração do campo da Ciência da Informação no escopo do contexto mais fluído da ciência pós-moderna.

Quanto ao terceiro elemento, fruto da intersecção das noções de documento e informação, denominamos genericamente "informação-documento" ou "documentoinformação", deixando em aberto a discussão sobre qual das expressões traduz melhor essa inter-relação dos termos. Além disso, também salientamos que a expressão “informação documentária” já é frequente na área, tendo sido inicialmente utilizada por autores franceses da década de 70 (por exemplo, Chaumier, 1971) e posteriormente, no Brasil, por pesquisadores do Grupo TEMMA. 
Concluímos, portanto, que os termos "documento" e "informação" perdem parte de seu valor ao serem encarados de forma isolada. Diante disso, propõe-se a analogia de uma relação simbiótica. Tal relação é ratificada na análise terminológica, ao revelar que além das similaridades e aproximações entre os termos, há uma verdadeira intersecção que permite que eles realmente constituam traços identitários da Ciência da Informação. 


\section{Referências}

ARAÚJO,C.A.A. O Conceito de Informação na Ciência da Informação. Informação e Sociedade: Estudos. João Pessoa, v.20, n.3, p.95-105, set./dez., 2010.

ARAÚJO, E. A. O fenômeno informacional na ciência da informação: abordagem teórico-conceitual. In: Castro, C. A. (org) Ciência da informação e biblioteconomia múltiplos discursos. São Luis: EDUFMA, 2002.

ARAÚJO, M. A. L. Transdisciplinaridade e educação. Revista de Educação. Salvador: CEAP. n. 8, p. 7 -19, dez/fev., 2000.

BARRETO, A.A. Transferência da informação para o conhecimento. In: AQUINO, M.A.(org.) O campo da Ciência da Informação-gênese, conexões e especificidades.João Pessoa: Editora Universitária; UFPB, p.49-60, 2002.

BARRETO, A.A.Uma história da Ciência da Informação.In: TOUTAIN, Lídia Brandão. (Org.). Para entender a Ciência da Informação. Salvador: Editora da Universidade Federal da Bahia, 2007.

BARROS, L.A. Curso básico de terminologia. São Paulo: EDUSP, 2004.

BAUMAN, Z. Modernidade líquida. Rio de Janeiro: Zahar, 2001.

BIDERMAN, M. T. C. A ciência da lexicografia. Alfa, São Paulo, 28 (supl.), p.1-26, 1984.

BORKO, H. Information Science: what is it? American Documentation. Washington, v. 19, n.1, jan. 1968.

BRANDÃO, C. A. L. A transdisciplinaridade. In: De PAULA, J. A. (org.) A transdisciplinaridade e os desafios contemporâneos. Belo Horizonte: IEAT/UFMG, 2008.

BRIER, S. Cybersemiotics: a transdisciplinary framework for information studies. Biosystems. v. 46, n. 1-2, april, p.188, 1998.

BRIET, S. Qu'est-ce que la documentation? Paris: Édit - Éditions Documentaires Industriales et Techniques, 1951. Disponível em:

<http://martinetl.free.fr/suzannebriet/questcequeladocumentation/briet.pdf/>.Acesso em 10 mar.10.

BROOKES, B. The foundations of information science: Part I: Philosophical Aspects. Journal of Information Science, n. 2, p. 125-133, 1980.

BUCKLAND, M.K. Information as thing. Journal of the American Society for Information Science (JASIS), v.45, n.5, p.351-360, 1991.

BUCKLAND, M.K. What is a document? Journal of the American Society for Information Science.v.48, p.808-809, 1997. 
BURKE, P. Uma história social do conhecimento: de Gutenberg a Diderot. Rio de Janeiro: Jorge Zahar, 2003.

CABRÉ, M.T. La terminologia: teoria, metodologia, aplicaciones. Barcelona: Ed. Antártida; Empúries, 1993.

CABRÉ, M.T. La terminologia hoy: concepciones, tendencias y aplicaciones. v.24, n.5, 1995. Disponível em: http://revista.ibict.br/index.php/ciinf/article/view/487

CABRÉ, M.T. La terminología: representación y comunicación. Barcelona: IULA-UPF, 1999.

CACALY, S. (Coord.). Dictionnaire encyclopédique de l'information et de la documentation. Paris: Nathan, 1997

CAPURRO, R. Epistemología y ciencia de la información.Enl@ce: Revista Venezolana de Información, Tecnología y Conocimiento.n.1, ano 4, p. 11-29, jan./abr., 2007.

CAPURRO, R. \& HJØRLAND, B. O conceito de informação. Perspectivas em Ciência da Informação, v.12, n.1, 2007. Disponível em: http://www.eci.ufmg.br/pcionline/ Acesso em 10 mai 10.

CHARAUDEAU, P; MAINGUENEAU, D. Dicionário de Análise do Discurso. São Paulo: Contexto, 2004.

CHAUMIER, J. Les techniques documentaires. Paris: Presses Universitaires de France, 1971. 126p. (Que sais-je?, 1419)

COOPER, D. As filosofias do mundo- uma introdução histórica.Trad. Dinah de Abreu Azevedo. São Paulo: Edições Loyola, 2002.

CORNELIUS, I.Theorizing Information for Information Science.Annual Review of Information Science and Technology.University College Dublin.p.393-425, 2002.

COURBIERES, C. La question documentaire à l'épreuve du numérique : le recours aux fondamentaux. Sciences de la Société.n.75, p.40-51, oct., 2008.

COUZINET,V. Complexidade e documento: a hibridação das mediações nas áreas em ruptura.RECIIS - Revista Eletrônica de Comunicação Informação Inovação e Saúde. Rio de Janeiro, v.3, n.3, p.10-16, set., 2009.

CUNHA, M. B.; CAVALCANTI, C. R.O. Dicionário de Biblioteconomia e Arquivologia.Brasília: Briquet de Lemos Livros, 2008.

CURRÁS, E. La información en sus aspectos-ciencias de la documentación. Madrid: Paraninfo, 1986.

DAY, R.The conduit metaphor and the nature and politics of information studies.Journal of the American Society for Information Science, july, 2000. 
DICIONÁRIO ELETRÔNICO DE TERMINOLOGIA EM CIÊNCIA DA

INFORMAÇÃO. DeltCI .Departamento de Ciência da Informação; Centro de Ciências Jurídicas e Econômicas: Universidade Federal do Espírito Santo, 2007.

DIAS, C.A. Terminologia: conceitos e aplicações. Ciência da Informação, Brasília, v. 29, n. 1, p. 90-92, jan./abr. 2000.

ESCARPIT, R. L'information et la communication: théorie générale. Paris: Hachette Superiour, 1991. (Hachette Université Communication). Inicialmente publicado em 1976 pela mesma editora.

ESTIVALS, R.; A dialética contraditória e o complemento da escrita e do documento. Revista da Escola de Biblioteconomia da UFMG, v.10, n.2, p.121-152, set., 1981.

FARIA, M. I., PERICÃO, M. G. Dicionário do livro: da escrita ao livro eletrônico. São Paulo: EDUSP, 2008.

FONDIN, H. La science de l'information ou le pois de l'histoire. Les enjeux de l'information et de la communication, Grenoble, 2005. Disponível em: $\lfloor$ http://w3.ugrenoble3.fr/les_enjeux/2005/Fondin/home.html>. Acesso em: 25 mai. 2010.

FOUCAULT. M. The archeology of knowledge and discourse on language. New York: Harpre Row, 2002.

FRANCKE,H. What's in a Name? Contextualizing the Document Concept.Literary and Linguistic Computing, v. 20, n. 1, 2005.Disponível em: http://llc.oxfordjournals.org Acesso em: 25 out 2010.

FREIRE,L.L.Seguindo Bruno Latour: notas para uma antropologia simétrica. Comum. Rio de Janeiro, v.11, n. 26, p. 46- 65, jan./jun. 2006.

FROCHOT, D. Définition de l'information. Les Infostratèges.Paris,2003.Disponível em : http://www.les-infostrateges.com Acesso em 13 jun. 10.

FROHMANN, B. Revisiting 'what is a document'. Journal of Documentation, v.66, n.2, p.291-303,2004 Disponível em:

http://www.fims.uwo.ca/people/faculty/frohmann/Documents/Revisiting_JDOC.pdf Acesso em 15 mai. 10.

FROHMANN, B. O caráter social, material e público da informação na contemporaneidade. In: ENCONTRO NACIONAL DE PESQUISA EM CIÊNCIA DA INFORMAÇÃO, 7., 19 a 22 nov. 2006, Marília. Anais... Marília: ANCIB ; UNESP, 2006.

GALVÃO, M. C. B. Construção de conceitos no campo da ciência da informação. Ciência da Informação. Brasília, v. 27, n. 1, p. 46-52, jan. /abr. 1998.

GARCÍA GUTIÉRREZ, A. La memoria subrogada- mediación, cultura y conciencia en la red digital. España : Universidad de Granada, 2002. 
GAUDIN, F.Pour une socioterminologie. Rouen: Publications Université de Rouen, 1993.

GONZÁLES de GOMES, M. N. Dos Estudos Sociais da Informação aos Estudos do Social desde o ponto de vista da informação. In: O Campo da Ciência da Informação: gênese, conexões e especificidades. João Pessoa: Editora Universitária, 2002.

GONZÁLEZ DE GOMES, M. N. Os vínculos e os conhecimentos: pensando o sujeito da pesquisa transdiciplinar. In: ENCONTRO NACIONAL DE CIENCIA DA INFORMAÇÃO, n.5, Belo Horizonte, 2003.

HARVEY, D. Condição pós-moderna. São Paulo: Loyola, 2000.

HJORLAND, B Information: Objective or Subjective/Situational? Journal of the American society for information science and technology. v.10, n.58, p.1448-1456, 2007.

ISO 1087-1. Terminology work - principles and methods. Part 1: theory and application; Travaux terminologiques - vocabulaire. Partie 1: théorie et application. Génève : ISO, 2000.

ISO 704. Principles and methods of terminology. $2^{\mathrm{a}}$.ed. Génève : ISO, 2000.

JAKOBIAK, F. Maîtriser l'information critique. Paris : Les éditions d'organisation, 1988.

JAPIASSU, H. Interdisciplinaridade e patologias do saber. Rio de Janeiro: Imago, 1976. (Série Logotica).

KOBASHI, N. Y.; A elaboração de informações documentárias: em busca de uma metodologia. 1994. Tese (Doutorado em Ciências da Comunicação) - Escola de Comunicação e Artes, Universidade de São Paulo, São Paulo, 1994.

KORNWACHS, K.; KOSNTANTIN,J.(ed.). Information: New Questions to a Multidisciplinary Concept. Berlin: Akademie Verlag, 1996.

LARA, M.L.G. A representação documentária: em jogo a significação. (Dissertação de Mestrado). São Paulo, ECA-USP, 1993.

LARA, M.L.G. Elementos de terminologia. São Paulo: ECA-USP, 2005 (Apostila para uso didático). Disponível em:

http://infobservatorio.incubadora.fapesp.br/portal/int_terminol/bibliografia/elemterm20 05.doc/view Acesso em: 25 ago.10.

LARA, M.L.G. de. Novas relações entre Terminologia e Ciência da Informação na perspectiva de um conceito contemporâneo da informação. DataGramazero, v.7, n.4, ago.2006. Disponível em: http://www.dgz.org.br/ago06/F_I_art.htm Acesso em: 25 ago 10 . 
LARA, M.L.G.Informação, informatividade e Linguiística Documentária: alguns paralelos com as reflexões de Hjorland e Capurro. DataGramaZero - Revista de Ciência da Informação, v.9, n.6, dez, 2008.

LATOUR, B. Redes que a razão desconhece: laboratórios, bibliotecas, coleções.In: BARATIN, M.; JACOB, C. O poder das bibliotecas: a memória dos livros no Ocidente.

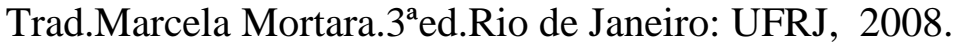

LE COADIC,Y.F. Le besoin d'information formulation, négociation, diagnostic . 2ed. Paris: ADBS, 2002.

LE COADIC, Y.F. A ciência da informação. São Paulo : Briquet Lemos, 2004.

LE GUERN, M. Sur les relations entre terminologie et lexique. Meta, v.34, n.3, p.340$343,1989$.

LEVY, D. Fixed or fluid? Document stability and new media. ECHT, Proceedings,p.2431, sep., 1994.

LILLEY, D.B;TRICE, R.W.A history of information science 1945-1985. United Kingdom: Academic Press, 1989 (Library and Information Series).

LÓPEZ YEPES, J. Teoría de la Documentación. Pamplona: EUNSA, 1978.

LÓPES YEPES, J. Reflexiones sobre el concepto de documento ante la revolución de la información: ¿un nuevo profesional del documento? Scire, Zaragoza, v.3, n.1, p.11-29, ene./jun. 1997.

LÓPEZ YEPES, J. Hombre y documento: del homo sapiens al homo documentator. Scire, Zaragoza, v. 4, n. 2, jul./dic, p. 11-22, 1998.

LUND, N. W. Document theory. Annual Review of Information Science and Technology, Medford, v. 43, p. 399-432, 2009.

LYOTARD, J. A condição pós-moderna. Rio de Janeiro: José Olympio, 1990.

MARCONDES. C.H. Linguagem e documento: fundamentos evolutivos e culturais da Ciência da Informação. Perspectiva em Ciência da Informação. v.15, n.2, p 2-21, maioago.,2010.

MARTINEZ-COMECHE, J.A. The nature and qualities of document in archives, libraries and information centres and museums. Journal of Spanish Research on Information Science, v.1, n.1, p.5-10, 2000.

MASSA DE GIL, B.; RAY, T,; GOY, M.; Diccionario técnico de biblioteconomía: español-inglés, english-spanish. México, D. F.: Centro de Ayuda Técnica, Agencia para el Desarrollo Internacional, c1964. 
MATHEUS, R.F.; Rafael Capurro e a filosofia da informação: abordagens, conceitos e metodologias de pesquisa para a Ciência da Informação. Perspectiva em ciência da Informação, Belo Horizonte, v.10 n.2, p.140-165, jul./dez. 2005.

MCGARRY, K. O contexto dinâmico da informação: uma análise introdutória. Brasília: Briquet de Lemos, 1999.

MEADOWS, A.J. A comunicação científica. Brasília: Briquet Lemos, 1999.

METZER, J.P. L'Information-documentation. In: OLIVESI, S.(dir)Sciences de l'information et de la communication-objet, savoirs, discipline. France : Presses Universitaires de grenobles,p.43-61, 2006.

MEYRIAT, J. Document, documentation, documentologie. Schéma et Schématisation. n. 14 , p. 51-63, $2^{\circ}$ trim., 1981.

MICHEL, $J$. L'information et documentation Un domaine d'activité professionnelle en mutation LCN - Les Métiers du Numérique .Hermès, v. 1, n.3, p. 47-64, 2000.

MIRANDA, A. A conceituação de massa documental e o ciclo de interação entre tecnologia e o registro do conhecimento. In: SIMEÃO, E.(org.) Ciência da informaçãoteoria e metodologia de uma área em expansão.Brasília:Thesaurus, 2003.

MOREIRO GONZÁLEZ, José Antonio. Conceptos introductorios al estudio de la información documental. Salvador: EDUFBA/Fondo Editorial de la Pontificia Universidad Católica del Perú, 2005.

MORIN, E.O método- as ideias, seu habitat, sua vida, seus costumes, sua organização. Rio Grande do Sul: Sulina, 1997.

MURGUIA, E. I.; GRIGOLETO, M. C. O documento e seu valor patrimonial. Os processos de tombamento do museu histórico pedagógico Prudente de Morais. In: X Encontro Nacional da Associação Nacional de Pesquisa e Pós Graduação em Ciência da Informação, 2009, João Pessoa. A responsabilidade social da ciência da informação. João Pessoa: Ideia, 2009.

OLIVEIRA, M.; ARAÚJO, E. A. Os paradigmas da biblioteconomia e da ciência da informação e os novos contextos de informação. In: CASTRO, C. A. (org.) Ciência da informação e biblioteconomia: múltiplos discursos. São Luis: EDFAMA, p. 36-49. 2002.

ORTEGA, C. D. Relações históricas entre Biblioteconomia, Documentação e Ciência da Informação. Datagramazero.v.5, n.5, out. 2004. Disponível em: http://www.dgz.org.br/out04/Art_03.htm. Acesso em 10 mar 10.

ORTEGA, C. D. Surgimento e consolidação da Documentação: subsídios para compreensão da história da Ciência da Informação no Brasil. Perspectivas em Ciência da Informação, v.14, número especial, p.59-79, 2009a. 
ORTEGA, C.D.Os registros de informação dos sistemas documentários: uma discussão no âmbito da Representação Descritiva. São Paulo. Tese (Doutorado em Ciência da Informação) Escola de Comunicações e Artes, Universidade de São Paulo (ECA/USP), $2009 \mathrm{~b}$.

ORTEGA, C.D .A documentação como uma das origens da ciência da informação e base fértil para sua fundamentação. BJIS, v.3, n.1, p.3-35, jan./jun. 2009c. Acesso em 28 fev.2011. Disponível em: http://www2.marilia.unesp.br/revistas/index.php/bjis Acesso em 26 jul. 10.

ORTEGA, C.D.Categorias configuradoras da Ciência da Informação: seleção, exploração e sistematização. Documentación de las Ciencias de la Información., v. 33, p. 289-328, 2010.

ORTEGA, C. LARA, M. L. G. A noção de documento: de Otlet aos dias de hoje.DataGramaZero - Revista de Ciência da Informação. v.11, n.2, abr, 2010.

OTLET, P. El Tratado de Documentación: el libro sobre el libro: teoría y práctica. Trad. por Maria Dolores Ayuso García. Murcia: Universidad de Murcia, 1997. Tradução de: Traité de Documentation: le livre sur le livre: théorie et pratique. Bruxelles: Mundaneum, 1934.

PAVEAU, M.A.;SARFATI,G.E. Fernand Saussure: a teorização da linguística moderna. In:__. As grandes teorias da Linguística: da gramática comparada à pragmática. Trad. De M.R. Gregolim et al. São Carlos: Claraluz, 2006.

PAVEL, S.: NOLET, D. Manual de terminologia. Disponível em: $\underline{\text { www.fit- }}$ ift.org/download/presport.pd

PÉDAUQUE. R. Document:forme, signe et medium, le reformulations de numériques.STIC-CNRS, 8 juillet 2003. Disponível em: http://archivesic.ccsd.cnrs.fr/sic_00000511.html Acesso em 23 jul. 2010.

PÉREZ TORNERO, J. M. Los nuevos procesos de mediación: del texto al hipermedia, en comunicación y educación en la sociedad de la información. Barcelona: Paidós, 2000 .

POMBO, O. Contribuição para um vocabulário sobre interdisciplinaridade. (selecção e organização). In: POMBO, O.; LEVY, T. e GUIMARAES, H. A Interdisciplinaridade: Reflexão e Experiência, Lisboa: Ed. Texto, $2^{\text {a }}$ edição (revista e aumentada), p. 92-97. 1994.

POPPER, K. R. Conhecimento objetivo: uma abordagem evolucionária. Belo Horizonte: Editora Itatiaia; São Paulo: Ed. da Universidade de São Paulo, v. 13,1975. (Espírito de Nosso Tempo).

RABELLO, R. O documento na Ciência da Informação: tradição e inovação conceitual a partir de uma abordagem histórica e metodológica. (Tese de Doutorado). São Paulo: Unesp, 2009. 
RADAMÉS LINARES, C. Ciencia de la Información. Su historia y epistemología. Bogotá, Colombia: Editorial Rojas Eberhard, 2005.

RAYWARD, W. B. The case of Paul Otlet, pioneer of information science, internationalist, visionary:reflections in biography. Journal of Librarianship and Information Scienc, v.23, p.135-145,sep., 1991.

REIG CRUAÑES, J. Para una teoría informativa del documento: extensión y aplicabilidad del concepto. Revista Interamericana de Bibliotecología. v. 28, n. 1, p. 1342, ene./jun, 2005.

RENDÓN ROJAS, M. A. Bases teóricas y filosóficas de la bibliotecología. 2. ed. México: UNAM, Centro Universitario de Investigaciones Bibliotecológicas, 2005. (Sistemas bibliotecarios de información y sociedad).

REY, A. La Terminologie: noms et notions. Paris: Presses Universitaires de France, 1979.

ROBREDO, J. Documentação de hoje e de amanhã: uma abordagem revisitada e contemporânea da ciência da informação e de suas aplicações biblioteconômicas, documentárias, arquivísticas e museológicas. $4^{\mathrm{a}}$ ed. Revista e ampliada. Brasília, DF: Edição de autor, 2005.

ROBREDO, J. Filosofia da ciência da informação ou ciência da informação e filosofia? In: TOUTAIN, L.B. (org.) Para entender a Ciência da Informação. Salvador: Editora da Universidade Federal da Bahia, 2007.

RODRÍGUEZ BRAVO, Blanca. El documento: entre La teoría y la renovación. Gijon, Trea, 2002.

ROS GARCÍA, J. El concepto de Documentación en la doctrina española.Primer Congreso Universitario de Ciencias de la Documentación.Universidad de Murcia, 2000.

SAGER, J.C. A practical course in terminology processing. Amsterdam: J. Benjamins, 1990.

SAGREDO FERNÁNDEZ, F.; IZQUIERDO ARROYO Reflexiones sobre "Documento": Palabra / objecto. Boletin Millares Carlo, n.3, p.161-197, 1982.

SAGREDO FERNÁNDEZ, F.; IZQUIERDO ARROYO, J. M. Concepción lógicolingüística de la Documentación. Madrid: IBERCOM, 1983.

SANTOS, B. S. Um discurso sobre as ciências. Porto: Afrontamento, 1987.

SARACEVIC, T. A natureza interdisciplinar da ciência da informação. Ciência da Informação, v.24, n.1, 1995.

SHANNON, C. E.,WEAVER,W. The Mathematical Theory of Communication. Urbana: University of Illinois Press, 1949. 
SILVA, A. M.; Arquivística, Biblioteconomia e Museologia: do empirismo patrimonialista ao paradigma emergente da CI. In: Integrar - $1^{\circ}$ Congresso Internacional de Arquivos, Bibliotecas, Centros de Documentação e Museus. São Paulo: FEBAB, p.573-607,2002.

SILVA, A. M.; Documentação e Informação: as questões ontológica e epistemológica. Porto: Universidade do Porto. Faculdade de Letras, 2006. Acesso em 15 jan.2011. Disponível em: http://repositorio-aberto.up.pt/handle/10216/8742

SILVA NETO.C.; SERRI, R. H. Pensamento complexo e inclusão informacional.In: PINTO, V. B.(org.).Ciência da Informação:abordagens transdisciplinares, gênese e aplicações.Fortaleza: Edições UFC, 2007.

SIMEÃO, E.Comunicação extensiva e Informação em Rede.Brasília: Universidade de Brasília, Departamento de Ciência da Informação e Documentação, 2006.

SIQUEIRA, J.C. Biblioteconomia, Documentação e Ciência da Informação: história, sociedade, tecnologia e pós-modernidade. Perspectiva em Ciência da Informação. v.15, n.3, p.52-66, set-dez, 2010.

SMIT, J.W. Arquivologia, Biblioteconomia e Museologia: o que agrega estas atividades profissionais e o que as separa? Revista Brasileira de Biblioteconomia e Documentação. Nova Série, v.1, n.2, p-27-36, 2000.

SMIT, J. W. Novas abordagens na organização, no acesso e na transferência da informação.In: SILVA, H.C; BARROS, M.H.T.C.Ciência da Informação-múltiplos diálogos. Marília: Oficina Universitária ;Unesp, 2008.

SMIT, J.W.; TÁLAMO, M.F.G.M.; KOBASHI, N.Y. A função da terminologia na construção do objeto da Ciência da Informação. DataGramaZero, v.2, n.2, abril, 2001. Disponível em: http://www.dgz.org.br/abr01/Art_03.htm Acesso em: 08 set.10.

SMIT, J. W.; TÁLAMO, M;F.G.M.; KOBASHI, N.Y.A determinação do campo científico da ciência da informação:uma abordagem terminológica. Datagramazero, v.5, n.1, fev., 2004.

SMIT, J. W.;TÁLAMO, M. F. G. M. Ciência da Informação: pensamento informacional e integração disciplinar. Brazilian Journal of Information Science,v.1, n.1, jan./jun., 2007. Disponível em: http://www.bjis.unesp.br/pt/index.php Acesso em: 25 jan.2011.

TÁLAMO, M. F. G. M. Terminologia e documentação. Tradterm, São Paulo, v. 1, n. 7, p. 141-151, 2001.

TÁLAMO, M. F. G. M. A Pesquisa: recepção da informação e produção do conhecimento. DataGramaZero.v.5, n.2, abril, 2004.

TÁLAMO, M.F.G.M.;LARA, M.L.G. de. O campo da Linguística Documentária. Transinformação, v.18, n. 3, set./dez.2005. Disponível em: http://revistas.puccampinas.edu.br/transinfo/index.php Acesso em:19 set.10. 
TÁLAMO, M de F. G. M.; SMIT, J. W. Ciência da informação: transgressão metodológica. In: BENTES PINTO, V.; CAVALCANTE, L.E.; SILVA NETO, C.

Ciência da Informação: abordagens transdisciplinares, gêneses e aplicações. Fortaleza: Ed. UFC, p.23-47, 2007.

TEIXEIRA COELHO, J. Esboços do prazer. In: MONTESQUIEU, C.S. O gosto. São Paulo: Iluminuras, p.83-127, 2005.

ULMANN, Stephen. Semântica. Trad. Coimbra: Fundação Calouste Gulbenkian, 1977.

WELKER,H.A. Dicionários- uma pequena introdução à Lexicografia. $2^{\mathrm{a} e d . r e v i s t a ~ e ~}$ ampliada. Brasília: Thesaurus, 2004.

WERSIG, G. Information Science: the study of postmodern knowledge usage. Information Processing \& Management, v. 29, n. 2, p.229-239, 1991.

WERSIG, G.; WINDEL, G. Information science needs a theory of 'information actions. Social Science Information Studies.v.5, n.1, p.11-23, 1985. 


\section{APÊNDICE A- FICHAS DE ANÁLISE}

\section{FICHA 1}

\section{Termo: Documento}

2 Referência: LUND, N. W. Document theory. Annual Review of Information Science and Technology, Medford, v. 43, p. 399-432, 2009.

3 Contexto: "[...] has suggested that one should view the document from three complementary angles: physical, social, and mental, in combination enabling a complete description. This does not mean that it can be viewed simultaneously as a physical, social, and mental phenomenon. From this perspective, the core issue is how these dimensions interact with each other in different ways. This depends on the physical, social, and cognitive environments in which documentation takes place, whether it is health care, the arts, business and politics".

4 Tradução: “[...]Sugere-se que se deva ver o documento, a partir de três ângulos complementares: físico, social e mental, que em combinação permitem uma descrição.Isso não significa que ele pode ser visto simultaneamente como um fenômeno físico, social e mental.Nesta perspectiva, a questão central é como essas dimensões interagem umas com as outras de diferentes maneiras.Isso vai depender do ambiente físico, social e cognitivo em que ocorre a documentação, seja de saúde, artes, negócios e política ".

\section{Características :}

5.1 Perspectiva objetiva, subjetiva e social: “[...]Sugere-se que se deva ver o documento, a partir de três ângulos complementares: físico, social e mental, que em combinação permitem uma descrição.Isso não significa que ele pode ser visto simultaneamente como um fenômeno físico, social e mental.Nesta perspectiva, a questão central é como essas dimensões interagem umas com as outras de diferentes maneiras.Isso vai depender do ambiente físico, social e cognitivo em que ocorre a documentação[...]”. 


\section{FICHA 2}

1 Termo: Documento

2 Referência: FRANCKE,H. What's in a Name? Contextualizing the Document Concept.Literary and Linguistic Computing, v. 20, n. 1, 2005.Disponível em: http://llc.oxfordjournals.org Acesso em: 25 out 2010.

3 Contexto: "[...] the term 'document' is understood in different disciplines and contexts, in particular in the two areas of Library and Information Science (LIS) and structured documents. While the notion of 'document' in both these areas is often considered secondary in importance to 'information' and 'text,' it has attracted quite some interest lately, not least because of the insistence on the document as a material object [...]It manifests an interest in documents that covers several disciplines and research areas, but also illustrates clearly that the understanding of the document concept is highly dependent on context. The particular context in which I am working is characterized by an interest in document analysis, especially document structures and their relation to the material form of documents, as seen from the perspective of knowledge organization, i.e. the representation of document collections for the purpose of storage, retrieval, and distribution of recorded knowledge[...]The document serves a social function in our society in that it is assumed to provide us with knowledge and to preserve that knowledge for future generations".

4 Tradução: "[...] O termo "documento" é entendido em diferentes disciplinas e contextos, sendo tomado como um elemento estruturado particularmente em duas áreas a Biblioteconomia e Ciência da Informação (LIS). Enquanto a noção de "documento" em ambas as áreas é frequentemente considerada secundária em importância, em relação à 'informação' e ao 'texto', ultimamente tem atraído bastante interesse, não apenas por causa da insistência do documento como um objeto material [...] o entendimento do conceito de documento é altamente dependente do contexto. [...] $\mathrm{O}$ documento atende a uma função social na nossa sociedade que é assumida de nos fornecer o conhecimento e para preservar esse conhecimento para o futuro gerações".

\section{Características:}

5.1 Perspectiva objetiva: " [...] documento como um objeto material [...]ou seja, a representação de coleções de documentos para fins de armazenamento, recuperação e distribuição de conhecimento registrado [...]".

5.2 Perspectiva social: "O documento atende a uma função social na nossa sociedade que é assumida de nos fornecer o conhecimento e para preservar esse conhecimento para o futuro gerações.[...] O termo "documento" é entendido em diferentes disciplinas e contextos[...] o entendimento do conceito de documento é altamente dependente do contexto". 


\section{FICHA 3}

1 Termo: Documento

2 Referência: RODRÍGUEZ BRAVO, Blanca. El documento: entre La teoría y la renovación. Gijon, Trea, 2002.

3 Contexto: "Al abordar el documento desde el punto de vista de su funcionalidad hemos visto que su esencia radica en su capacidad para comunicar información que se encuentra fijada a un soporte. Tanto el estudio filológico como el antropológico coinciden en que el documento es un instrumento fundamentalmente informativo [...] Dicho esto hay que responder la pregunta: qué es un documento? En nuestra opinión, un documento, en el contexto en que nos movemos de la ciencia de la documentación, es un soporte portador de un mensaje emitido con intención comunicativa y potencialmente informativo para el receptor[...]En la noción do documento creemos necesaria la intención comunicativa del emisor, es decir, para que un ente se pueda considerar documento tiene que tener una finalidad informativa[...]"

\section{Características:}

4.1 Perspectiva objetiva: "[...] su capacidad para comunicar información que se encuentra fijada a un soporte $[\ldots]$ es un soporte portador de un mensaje[...]".

4.2 Perspectiva subjetiva:'"[...] portador de un mensaje emitido con intención comunicativa y potencialmente informativo para el receptor[...]"En la noción do documento creemos necesaria la intención comunicativa del emisor, es decir, para que un ente se pueda considerar documento tiene que tener una finalidad informativa[...]".

4.3 Perspectiva social: “[...] el antropológico coinciden en que el documento es un instrumento fundamentalmente informativo [...] 


\section{FICHA 4}

1 Termo: Documento

2 Referência: COUZINET,V. Complexidade e documento: a hibridação das mediações nas áreas em ruptura.RECIIS - R. Eletr. de Com. Inf. Inov. Saúde. Rio de Janeiro, v.3, n.3, p.10-16, set., 2009.

3 Contexto: "A posição, que consideramos central nas ciências da informação, deste objeto concreto que é o documento,convida-nos a tê-lo prioritariamente para as nossas análises. Ele é de fato, o modo no qual a informação, o conteúdo, ganham forma no plano comunicacional e é, ao mesmo tempo, o suporte que possibilita a sua circulação.[...]De nossa parte, e no sentido de contribuir para a elaboração coletiva de uma teoria do documento, desejaríamos voltar a dimensionar igualmente continente e conteúdo. As pesquisas realizadas sobre hibridações nos levaram a refletir sobre um tipo de uso pouco estudado até então. Em vez de nos colocar a questão do usuário/leitor,colocamos a questão do usuário-conceptor[...]O documento por intenção é aquele que serve para fixar acordos, extrair dados, o documento por atribuiçãoé um suporte que contem informações, mas que foi fabricado com outra intenção.Na maioria das vezes,tratam-se de objetos materiais diversos, que guardam o registro de uma civilização, de uma arte de fazer ou de um uso preciso. Contudo, e aí está talvez o elemento essencial, não existe documento em si[...] "ele está adormecido". Para ativá-lo e lhe conferir a sua função de portador de um conteúdo informacional, é necessário questioná-lo. Assim a questão ou o interesse conferido ao documento, de alguma forma o desperta e o revela. A noção de informação muda, então. Deixa de se limitar a um conteúdo e se vincula a um processo, impulsionado pela vontade de se informar. Não existe documento a não ser ligado a essa vontade".

\section{Características:}

4.1 Perspectiva objetiva: "Ele é de fato, o modo no qual a informação, o conteúdo, ganham forma no plano comunicacional e é, ao mesmo tempo, o suporte que possibilita a sua circulação[...]A posição, que consideramos central nas ciências da informação, deste objeto concreto que é o documento,convida-nos a tê-lo prioritariamente para as nossas análises(...)o documento por atribuição é um suporte que contem informações, mas que foi fabricado com outra intenção".

4.2 Perspectiva subjetiva: "Em vez de nos colocar a questão do usuário/leitor, colocamos a que estão do usuário-conceptor [...] O documento por intenção é aquele que serve para fixar acordos, extrair dados[...] Contudo, e aí está talvez o elemento essencial, não existe documento em si[...] "ele está adormecido". Para ativá-lo e lhe conferir a sua função de portador de um conteúdo informacional, é necessário questioná-lo. Assim a questão ou o interesse conferido ao documento, de alguma forma o desperta e o revela. A noção de informação muda, então. Deixa de se limitar a um conteúdo e se vincula a um processo, impulsionado pela vontade de se informar. "Não existe documento a não ser ligado a essa vontade". 
4.3 Perspectiva social - "[...] $\mathrm{Na}$ maioria das vezes, tratam-se de objetos materiais diversos, que guardam o registro de uma civilização, de uma arte de fazer ou de um uso preciso". 


\section{FICHA 5}

1 Termo: Documento

2 Referência:. REIG CRUAÑES, J. Para una teoría informativa del documento: extensión y aplicabilidad del concepto. Revista Interamericana de Bibliotecología. v. 28, n. 1, p. 13-42, ene./jun, 2005.

3 Contexto: "La concepción informativa del documento, emparentada con la perspectiva antropológica, se encontraba ya en Paul Otlet cuando entendía al libro en su conjunto como "memoria materializada de la humanidad". Esta concepción, hoy lo sabemos, debe ser aplicable a todo tipo de objeto informativo y no sólo a los libros. Son sino medios para transmitir información $\mathrm{y}$, como tales, podemos considerarlos documentos, es decir, "manifestación de un contenido informativo". La fijación de información sobre algún soporte material con la intención de transmitirla conforma, lo hemos visto, el documento. Esto significa que, estructuralmente, el documento se compone de un mensaje informativo y un soporte que le sirve de vehículo. Esto convierte al documento en una sucesión de signos o secuencia de señales: para que un signo pueda formar un mensaje debe poseer un referente reconocible por emisor y receptor. Todo conjunto de signos puede ser considerado un documento en cuanto tenga un receptor potencial. Es decir, en cuanto hay una persona para la que aquel conjunto de signos constituye información. La noción de documento puede reducirse así, a un mensaje icónico o simbólico[...]”.

\section{Características:}

4.1 Perspectiva objetiva: "La fijación de información sobre algún soporte material (...)Esto significa que, estructuralmente, el documento se compone de un mensaje informativo y un soporte que le sirve de vehículo".

4.2 Perspectiva subjetiva: " Esto convierte al documento en una sucesión de signos o secuencia de señales: para que un signo pueda formar un mensaje debe poseer un referente reconocible por emisor y receptor. Es decir, en cuanto hay una persona para la que aquel conjunto de signos constituye información. La noción de documento puede reducirse así, a un mensaje icónico o simbólico[...]Son sino medios para transmitir información y, como tales, podemos considerarlos documentos, es decir, "manifestación de un contenido informativo".

4.3 Perspectiva social: "La concepción informativa del documento, emparentada con la perspectiva antropológica, se encontraba ya en Paul Otlet cuando entendía al libro en su conjunto como "memoria materializada de la humanidad". 


\section{FICHA 6}

1 Termo: Documento

2 Referência:. PÉDAUQUE. R. Document: forme, signe et medium, le reformulations de numériques.STIC-CNRS, 8 juillet 2003. Disponível em: http://archivesic.ccsd.cnrs.fr/sic_00000511.html Acesso em 23 jul. 2010.

3 Contexto: "Le document comme forme: sous cette rubrique, nous rangerons les approches qui analysent le document comme um object matériel ou immatériel et qui em étudient la structure pour mieux l'analyser,l'útiliser ou le manipuler.Le document comme signe: pour ses chercheurs le document est perçu avant tout comme porte des sens et douté d'une intentionnalité;ainsi le document est indissociable du sujet en context qui le construit ou le reconstruit et lui donne sens; en même temps, il est pris dans un système documentaire ou un système de connaissances. Le document comme medium: cette dimension enfin post la question du statut du document dans le relations sociales; le document est un trace, construite ou retrouvée, d'une communication qui s' est affranchie de l'espace et du temps; en même, il est un élément des systèmes identitaires et un vecteur du pouvoir".

4 Tradução: "O documento como forma: nesta rubrica, vamos organizar as abordagens que analisam o documento como um objeto material ou imaterial e que se estuda a estrutura por meio da análise, utilização ou a manipulação.O documento como signo: caráter pelos seus pesquisadores,é visto principalmente como um portador de significado e intencionalidade e dúvida, e é inseparável do sujeito no contexto que, construído ou reconstruído e lhe dá sentido e ao mesmo tempo ele está preso em um sistema de recuperação ou em um sistema conhecimentos. O seu papel como um meio: está voltado à dimensão da finalidade de postar o status do documento nas relações sociais. $\mathrm{O}$ documento é um traço, construído ou encontrado em uma comunicação livre no espaço e tempo; Todavia, existe um elemento de sistemas de identidade e um vetor de poder ".

\section{Características:}

5.1 Perspectiva objetiva: "O documento como forma: nesta rubrica, vamos organizar as abordagens que analisam o documento como um objeto material ou imaterial e que se estuda a estrutura por meio da análise, utilização ou a manipulação".

5.2 Perspectiva subjetiva: "O documento como signo: caráter pelos seus pesquisadores,é visto principalmente como um portador de significado e intencionalidade e sem dúvida, e é inseparável do sujeito [...]".

5.3 Perspectiva social: "O seu papel como um meio: está voltado à dimensão da finalidade de postar o status do documento nas relações sociais"[...] "O documento é um traço, construído ou encontrado em uma comunicação livre no espaço e tempo; [...]e sem dúvida, e é inseparável do sujeito no contexto construído ou reconstruído e lhe dá 
sentido e ao mesmo tempo ele está preso em um sistema de recuperação ou em um sistema conhecimentos". 


\section{FICHA 7}

1 Termo: Informação

2 Referência: FONDIN, H. La science de l'information ou le pois de l'histoire. Les enjeux de l'information et de la communication, Grenoble, 2005. Disponível em: <http://w3.u-grenoble3.fr/les_enjeux/2005/Fondin/home.html >. Acesso em: 25 mai. 2010.

3 Contexto: "Classiquement, on considere que l'information c'est le contenu d'un message. C'est l'objet même d'un échange entre deux entités distinctes qu'elles soient naturelles. [...]Ainse de nombreuses sciences, celles qui étudient les phénoménes de la vie et du mouvement - physique, biologie, droit, science de la communication, science de l'information - intègrent le concept de 'contenu' et avec lui le mot 'information' dans leur outillage[...] L'information est donc objet d'étude pour toutes ces sciences car un objet social n'appartient de droit à aucune science.[...]Pour la plupart des spécialsites de la SI, le concept 'information' recouvre un contenu bien particulier car c'est généralement l'objet d'un échange intentionnnel (et non pas fortuit), car fait pour 'faire savoir'. Pour la SI, 'information' est ainsi assimilée à 'connaissance communiquée'[...]L'objet de la SI est classicament l'information intentionnelle, la connaissance communiquée. »

4 Tradução: "Classicamente considera-se que a informação é conteúdo de uma mensagem. É o mesmo objeto de uma troca entre duas entidades distintas que sejam naturais [...] Também numerosos cientistas, aqueles que estudam os fenômenos da vida e do movimento- física, biologia, direito ciência da comunicação e ciência da informação - entendem o conceito do conteúdo integrado à palavra informação como uma ferramenta [...] A informação é, portanto objeto de estudo para todas as ciências, porque é um objeto social que não pertence de direito a nenhuma ciência. [...] Para a maior parte dos especialistas da Ciência da Informação, o conceito 'informação' recobre um conteúdo bem particular, porque é geralmente o objeto de um troca intencional (e não imprevista), porque permite um 'saber fazer'. O objeto da Ciência da Informação é classicamente a informação intencional, o conhecimento comunicado".

\section{Características:}

5.1 Perspectiva objetiva: "entendem o conceito do conteúdo integrado à palavra informação como uma ferramenta".

5.2 Perspectiva subjetiva: "Classicamente considera-se que a informação é conteúdo de uma mensagem. É o mesmo objeto de uma troca entre duas entidades distintas que sejam naturais. [...]"Para a maior parte dos especialistas da Ciência da Informação, o conceito 'informação' recobre um conteúdo bem particular, porque é geralmente o objeto de um troca intencional (e não imprevista), porque permite um saber fazer". 
5.3 Perspectiva social: "A informação é, portanto objeto de estudo para todas as ciências, porque é um objeto social[...]”. 


\section{FICHA 8}

1 Termo: Informação

2 Referência:. LATOUR, B. Redes que a razão desconhece: laboratórios, bibliotecas, coleções.In: BARATIN, M.; JACOB, C. O poder das bibliotecas: a memória dos livros no Ocidente. Trad.Marcela Mortara.3 ${ }^{\mathrm{a}}$ ed.Rio de Janeiro: UFRJ, p.22-24, 2008.

3 Contexto: "A informação não é um signo, e sim uma relação estabelecida entre dois lugares: o primeiro, que se torna uma periferia, e o segundo, que se torna um centro, sob a condição de que entre os dois circulem um veículo que denominamos muitas vezes forma, mas que, para insistir em seu aspecto material, eu chamo de inscrição[...] Organizar a informação permite justamente limitar-se à forma, sem ter o embaraço da matéria[...]Verifica-se que a informação não é uma 'forma' no sentido platônico do termo, e sim uma relação muito prática e muito material entre dois lugares, o primeiro dos quais negocia o que deve retirar do segundo, a fim de mantê-lo sob sua vista e agir à distância sobre ele[...]A Informação não é inicialmente um signo, e sim o carregamento em inscrições cada vez mais móveis e cada vez mais fiéis, de um maior número de materiais".

\section{Características:}

4.1 Perspectiva objetiva: "[...] sob a condição de que entre os dois circulem um veículo que denominamos muitas vezes forma, mas que, para insistir em seu aspecto material, eu chamo de inscrição[...] Organizar a informação permite justamente limitar-se à forma, sem ter o embaraço da matéria[...]".

4.2 Perspectiva subjetiva:“[...]A Informação não é inicialmente um signo, e sim o carregamento em inscrições cada vez mais móveis e cada vez mais fiéis, de um maior número de materiais".

4.3 Perspectiva social: “A informação não é um signo, e sim uma relação estabelecida entre dois lugares: o primeiro, que se torna uma periferia, e o segundo, que se torna um centro[...]Verifica-se que a informação não é uma 'forma' no sentido platônico do termo, e sim uma relação muito prática e muito material entre dois lugares, o primeiro dos quais negocia o que deve retirar do segundo, a fim de mantê-lo sob sua vista e agir à distância sobre ele[...]". 


\section{FICHA 9}

\section{Termo: Informação}

2 Referência:. CORNELIUS, I.Theorizing Information for Information Science.Annual Review of Information Science and Technology.University College Dublin.p.393425,2002 .

3 Contexto: "The information is the meaning of the message together with any relevant contextual information available to the recipient. This is partly convention, which takes the position that messages in any context are meaningfully stable but that the information content is a subjective construction of the recipient.[...]Meaning, in a constructivist argument, is negotiated in interaction in relation to other meanings just as one learns the language of forms of life by interaction, experience, and use.[...]These establish understanding; so in communication the process of communicating any one piece of information is wrapped in a net of meanings, all of which are socially negotiated and which combine to influence or determine what constitutes the information and what the information content is.[...]Constructivist claims that emphasize the uniqueness of the individual experience of information, maintaining that there is no information independent of our social practices[...]".

4 Tradução: "A informação é o significado da mensagem, juntamente com todas as informações contextuais relevantes à disposição do destinatário. Esta é a parte da convenção, que leva a posição de que as mensagens em qualquer contexto são significativamente estáveis, mas que o conteúdo da informação é uma construção subjetiva do destinatário .(...) Ou seja,segundo o argumento construtivista,a informação é negociada na interação em relação a outros sentidos, assim como se aprende a linguagem das formas de vida através da interação, experiência e uso. [...] Estas estabelecem o entendimento, a partir do processo de comunicação que transmite qualquer parte da informação, que está envolvida em uma rede de significados, que são socialmente negociado e que se combinam para influenciar ou determinar o que constitui a informação e qual seu conteúdo informacional.[...] $\mathrm{O}$ argumento construtivista que enfatizam a singularidade da experiência individual de informação, sustentando que não há nenhuma informação independente de nossas práticas sociais $[\ldots] "$.

\section{Características:}

\subsection{Perspectiva objetiva: -}

5.2 Perspectiva subjetiva: "A informação é o significado da mensagem [...] conteúdo da informação é uma construção subjetiva do destinatário.[...]A informação é o significado da mensagem, juntamente com todas as informações contextuais relevantes à disposição do destinatário(...)Esta é a parte da convenção, que leva a posição de que as mensagens em qualquer contexto são significativamente estáveis [...]". 
5.3 Perspectiva social: "O argumento construtivista que enfatizam a singularidade da experiência individual de informação, sustentando que não há nenhuma informação independente de nossas práticas sociais [...]Estas estabelecem o entendimento, a partir do processo de comunicação que transmite qualquer parte da informação, que está envolvida em uma rede de significados, que são socialmente negociados e que se combinam para influenciar ou determinar o que constitui a informação e qual seu conteúdo informacional". 


\section{FICHA 10}

\section{Termo: Informação}

2 Referência:. ROS GARCÍA, J. El concepto de Documentación en la doctrina española.Primer Congreso Universitario de Ciencias de la Documentación.Universidad de Murcia, 2000.

3 Contexto: "Efectivamente, la información, concepto a todas luces amplio y ambiguo por polisémico, proporciona el marco al concepto de Documentación, de tal modo que todo lo que se predica de la Información puede predicarse de la Documentación. El proceso documental es un proceso informativo que se caracteriza por ser el lugar donde se introduce información documental, es decir, información que se recupera a partir de mensajes previamente emitidos y conservados. Sin duda, la clave del arco representado por el proceso informativo es el mensaje. A través de numerosos escritos, una concepción ciertamente lúcida y fecunda del mensaje informativo, lo que le ha permitido establecer los distintos y básicos tipos de mensajes : de hechos, de ideas y de opiniones. Todo ello debe tener su correspondiente reflejo al trasladarse a la doctrina del mensaje documentario, mensaje en el que se embalsa y acondiciona el mensaje informativo, el cual logra pervivir -gracias al soporte documental y las técnicas documentarias- más allá del espacio y del tiempo.[...]Desde el momento en que se incorpora el mensaje informativo al soporte físico constituyendo el documento hasta el momento en que el mensaje alimenta la creación de un autor dando lugar a otro nuevo documento, y así en una cadena sin fin, en la que el documento aparece como factor siempre potenciador y semilla imprescindible de nueva información sin límites en el tiempo".

\section{Características:}

4.1 Perspectiva objetiva: "[...] el mensaje informativo, el cual logra pervivir -gracias al soporte documental y las técnicas documentarias- más allá del espacio y del tiempo.[...] Desde el momento en que se incorpora el mensaje informativo al soporte físico constituyendo el documento hasta el momento en que el mensaje alimenta la creación de un autor dando lugar a otro nuevo documento, y así en una cadena sin fin, en la que el documento aparece como factor siempre potenciador y semilla imprescindible de nueva información sin límites en el tiempo".

4.2 Perspectiva subjetiva: "El proceso documental es un proceso informativo que se caracteriza por ser el lugar donde se introduce información documental, es decir, información que se recupera a partir de mensajes previamente emitidos y conservados. Sin duda, la clave del arco representado por el proceso informativo es el mensaje. A través de numerosos escritos, una concepción ciertamente lúcida y fecunda del mensaje informativo, lo que le ha permitido establecer los distintos y básicos tipos de mensajes : de hechos, de ideas y de opiniones". 


\section{FICHA 11}

\section{Termo: Informação}

2 Referência:. DAY, R. The conduit metaphor and the nature and politics of information studies.Journal of the American Society for Information Science, july, 2000 .

3 Contexto: "[...]how "information" is understood as an important cultural concept for us today, and for our future, as a so-called "global information" society[...]As constructed through the conduit metaphor, "information" has, among other qualities, that of being quantifiably measurable and "factual," in the sense of being clear and distinct semantic units. These qualities are reflected in the goal of information transmission, namely, the sending and receiving of an originary message with as little extraneous "noise" or interference as possible[...]".

4 Tradução: "[...] Como "informação" é entendida como um conceito cultural importante para nós hoje, e para o nosso futuro, pode ser denominada como "Informação global" da sociedade [...] Como é construída por meio da metáfora do conduto, a informação tem, entre outras qualidades, a de ser mensurável e quantificável "factual", no sentido de ser clara e distinta em unidades semânticas. Estas qualidades são refletidas no objetivo de transmissão de informações, ou seja, o envio e recebimento de uma mensagem original com o mínimo de ruído "estranho" ou interferência possível[...]".

\section{Características:}

5.1 Perspectiva objetiva: " [...]a informação tem, entre outras qualidades, a de ser mensurável e quantificável "factual", no sentido de ser clara e distinta em unidades semânticas."

5.2 Perspectiva subjetiva: "Estas qualidades são refletidas no objetivo de transmissão de informações, ou seja, o envio e recebimento de uma mensagem original com o mínimo de ruído "estranho" ou interferência possível".

5.3 Perspectiva social: "[...] Como "informação" é entendida como um conceito cultural importante para nós hoje, e para o nosso futuro, pode ser denominada como "Informação global" da sociedade [...]". 


\section{FICHA 12}

1 Termo: Informação

2 Referência: RODRÍGUEZ BRAVO, Blanca. El documento: entre la teoría y la renovación. Gijon, Trea, 2002.

3 Contexto: "Existen distintas aproximaciones al concepto de información, pero se pueden resumir en cuatro: aquella que la considera una realidad objetiva, medible y cuantificable, y que en su afán de la objetividad olvida los aspectos semánticos, fundamentales para nuestra ciencia. La aproximación subjetiva que considera la información como algo situacional, variable en función del receptor y de su estado de conocimiento. La que la considera un ente material u se fija fundamentalmente en la información registrada en un suporte. Aquella que considera la información como el proceso de devenir informado. Es a través de ese proceso como diferentes individuos crean diferentes imágenes o ideas (información subjetiva) desde las mismas informaciones externas (información objetiva).

\section{Características:}

4.1 Perspectiva objetiva: “[...]aquella que la considera una realidad objetiva, medible y cuantificable, y que en su afán de la objetividad olvida los aspectos semánticos, fundamentales para nuestra ciencia[...] La que la considera un ente material u se fija fundamentalmente en la información registrada en un suporte”.

4.2 Perspectiva subjetiva: "[...]La aproximación subjetiva que considera la información como algo situacional, variable en función del receptor y de su estado de conocimiento. Es a través de ese proceso como diferentes individuos crean diferentes imágenes o ideas (información subjetiva) desde las mismas informaciones externas (información objetiva)". 


\section{APÊNDICE B- FICHAS DE SÍNTESE}

\begin{tabular}{|l|l|}
\hline Termo & Definição \\
\hline Documento & $\begin{array}{l}\text { “A noção de documento pode ser entendida a partir de } \\
\text { três perspectivas complementares: a objetiva, a subjetiva } \\
\text { e a social. Na primeira, o documento é visto como um } \\
\text { objeto material, com função de suporte ou meio portador } \\
\text { de uma mensagem informativa. Na perspectiva subjetiva, } \\
\text { considera-se o papel do documento em representar um } \\
\text { conteúdo informativo que é ativado apenas quando um } \\
\text { sujeito lhe atribui sentido, destacando-se aí a intenção } \\
\text { comunicativa do sujeito receptor. E na última, destaca-se } \\
\text { a função social do documento, marcada pelo acesso e } \\
\text { preservação do conhecimento, bem como pelo fato dele } \\
\text { servir como meio para as relações sociais. Além disso, } \\
\text { considerando que o documento é utilizado na } \\
\text { comunicação em um espaço e tempo determinados, sua } \\
\text { existência está intimamente vinculada aos sujeitos } \\
\text { (emissor e receptor) e ao contexto em que foi criado”. }\end{array}$ \\
\hline
\end{tabular}

\begin{tabular}{|l|l|}
\hline Termo & Definição \\
\hline Informação & $\begin{array}{l}\text { "Pode ser entendida a partir de três perspectivas } \\
\text { complementares: a objetiva, a subjetiva e a social. Na primeira } \\
\text { ressalta-se a ideia de informação como uma mensagem } \\
\text { informativa que está registrada em um suporte (documento), } \\
\text { destacando-se sua materialidade e o fato de ser mensurável, } \\
\text { quantificável e factual. Na perspectiva subjetiva privilegia-se a } \\
\text { construção da informação pelo sujeito, observando assim a } \\
\text { informação como algo que varia em função do receptor e de } \\
\text { seu estado de conhecimento. Já na perspectiva social fica em } \\
\text { destaque a informação como rede de significados socialmente } \\
\text { negociados, dependentes de situaçães comunicativas e do } \\
\text { contexto". }\end{array}$ \\
\hline
\end{tabular}

